University of Chicago Law School

Chicago Unbound

\title{
Disaggregating Gender from Sex and Sexual Orientation: The Effeminate Man in the Law and Feminist Jurisprudence
}

Mary Anne Case

Follow this and additional works at: https://chicagounbound.uchicago.edu/journal_articles

Part of the Law Commons

\section{Recommended Citation}

Mary Anne Case, "Disaggregating Gender from Sex and Sexual Orientation: The Effeminate Man in the Law and Feminist Jurisprudence," 105 Yale Law Journal 1 (1995).

This Article is brought to you for free and open access by the Faculty Scholarship at Chicago Unbound. It has been accepted for inclusion in Journal Articles by an authorized administrator of Chicago Unbound. For more information, please contact unbound@law.uchicago.edu. 


\title{
Articles
}

\section{Disaggregating Gender from Sex and \\ Sexual Orientation: The Effeminate Man \\ in the Law and Feminist Jurisprudence}

Mary Anne C. Case ${ }^{\dagger}$

\author{
CONTENTS
}

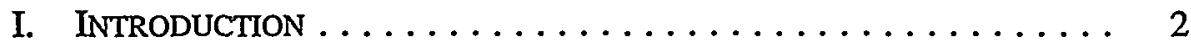

II. ON TERMinology: GendeR IS FOR ADJECTIVES, SEX Is FOR NOUNS . . . . . . . . . . . .

III. HISTORY AND THEORY OF GENDER BENDING:

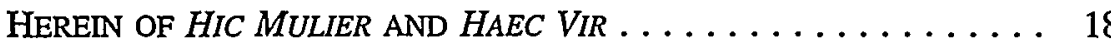

+ Professor of Law, University of Virginia School of Law. Displaying a valuable combination of "feminine" nurturance and "masculine" incisiveness, countless people assisted me in developing the ideas set forth in this Article. A few deserve special thanks for providing extraordinary help at crucial times: They include Mary Becker, Martha Fineman, John Harrison, Pam Karlan, Julia and Paul Mahoney, Dinah PoKempner, Todd Preuss, Reva Siegel, Susan Sturm, Rip Verkerke, and Ann Woolhandler. Among the many others to whom I am no less grateful are Ken Abraham, Kathy Abrams, Dianne Avery, David Bauer, Eileen Boris, Sarah Burns, Lynn Chancer, Mary Coombs, Sarah Corse, Bill Eskridge, Chai Feldblum, Lucinda Finley, Susan Fiske, Katharine Franke, Clark Freshman, Pat Gill, Clay Gillette, Louise Halper, Joe Harder, Alex Johnson, Jody Kraus, Nancy Levit, Debra Livingston, John Manning, Dayna Matthew, Richard McAdams, Linda McClain, Karlin Meyer, John Monahan, Dan Ortiz, Charlotte Patterson, Lee Pershan, John Portman, Gene Rogers, Dick Rorty, George Rutherglen, Ilona Schultz, Buffie Scott, Mike Seidman, Richard Slade, Bill Stuntz, Kendall Thomas, Rene Todd, Paula Vaeth, Frank Valdes, Larry Walker, Glenn Wallach, Ted White, Joan Williams, Evan Wolfson; and participants in the Columbia Law School Feminism and Legal Theory Workshop on the Limits of Essentialism, the National Women Law Students' Association 1994 Conference, and my 1994 class in Feminist Jurisprudence. I am also indebted to my research assistants Eleanor Magers, Julia McDonough, Emmy Paulette, Linda Rosenthal, Devin Schaumberg, Stacey Shawn, Leslie Weaver, Stephanie Webster, and Kim Willoughby; to Kent Olson for reference help; and to Gary Banks, Heidi Reavis, Rick Scarola, Scarola \& Reavis, and Bob Tilewick for technical assistance. 
IV. The Case Law of Gender Bending $\ldots \ldots \ldots \ldots \ldots \ldots \ldots 36$

A. Herein of Ann Hopkins and Bennie Smith . . . . . . . . 36

1. Hopkins and Sex Stereotyping .............. 36

2. Smith, Strailey, and Effeminacy ........... 46

B. Applying Hopkins . . . . . . . . . . . . . . . 57

1. Sexual Orientation and Hostile Environments ....... 57

2. Men in Dresses (or "Rebel-Rousing, Skirt-Wearing Persons") ...................... 61

3. Feminine Women .................. 69

V. INCORPORATING THE CONCEPT OF GENDER DISCRIMINATION INTO LEGAL DOCTRINE . . . . . . . . . . . . . . . 75

VI. BEYOND TITLE VII (AND BEYOND SAMENESS

AND DIFFERENCE? . . . . . . . . . . . . . . .

\section{INTRODUCTION}

The word "gender" has come to be used synonymously with the word "sex" in the law of discrimination. In women's studies and related disciplines, however, the two terms have long had distinct meanings, with gender being to sex what masculine and feminine are to male and female. Were that distinct meaning of gender to be recaptured in the law, great gains both in analytic clarity and in human liberty and equality might well result. For, as things now stand, the concept of gender has been imperfectly disaggregated in the law from sex on the one hand and sexual orientation on the other. Sex and orientation exert the following differential pull on gender in current life and law: When individuals diverge from the gender expectations for their sex-when a woman displays masculine characteristics or a man feminine ones-discrimination against her is now treated as sex discrimination while his behavior is generally viewed as a marker for homosexual orientation and may not receive protection from discrimination. This is most apparent from a comparison of Price Waterhouse v. Hopkins, ${ }^{1}$ in which the Supreme Court held it to constitute impermissible sex stereotyping to advise a female candidate for an accounting partnership that she should "walk more femininely, talk more femininely, dress more femininely, wear make-up, have her hair styled, ... wear jewelry," and go to "charm school,"2 with cases upholding

1. 490 U.S. 228 (1989).

2. Id. at 235 . 
an employer's right to fire or not to hire males specifically because they were deemed "effeminate."

This differential treatment has important implications for feminist theory. It marks the continuing devaluation, in life and in law, of qualities deemed feminine. The man who exhibits feminine qualities is doubly despised, for manifesting the disfavored qualities and for descending from his masculine gender privilege to do so. The masculine woman is today more readily accepted. Wanting to be masculine is understandable; it can be a step up for a woman, and the qualities associated with masculinity are also associated with success.

We are in danger of substituting for prohibited sex discrimination a still acceptable gender discrimination, that is to say, discrimination against the stereotypically feminine, especially when manifested by men, but also when manifested by women. Ann Hopkins, I fear, may have been protected only because of the doubleness of her bind: It was nearly impossible for her to be both as masculine as the job required and as feminine as gender stereotypes require. But the Supreme Court seems to have had no trouble with the masculine half of Hopkins's double bind; there is little indication, for example, that the Court would have found it to be sex discrimination if a prospective accounting partner had instead been told to remove her makeup and jewelry and to go to assertiveness training class instead of charm school.

Therefore, quite apart from the concerns we have for men, particularly effeminate men, in and of themselves, it is important for women and feminists to concern themselves with the treatment of the effeminate man. ${ }^{4}$ This is because, analogous to the argument made by those who seek to integrate pinkcollar ghettos, it may be that certain behaviors are just like certain jobs-they will not be valued unless and until men can feel free to engage in them. So long as stereotypically feminine behavior, from wearing dresses and jewelry to speaking softly or in a high-pitched voice, to nurturing or raising children, is forced into a female ghetto, it may continue to be devalued.

3. Smith v. Liberty Mut. Ins. Co., 569 F.2d 325, 327 (5th Cir. 1978); see also Strailey v. Happy Times Nursery Sch., reported as part of DeSantis v. Pacific Tel. \& Tel. Co., 608 F.2d 327 (9th Cir. 1979). One might be tempted to respond that Smith and Strailey, circuit court cases from the mid-1970s, have simply been overruled by the Supreme Court's 1989 Hopkins decision. I believe this to be the correct interpretation, but $I$ shall set forth at length below the reasons why courts and commentators, unfortunately not without reason, still treat these cases as good law. Not only has no case successfully applied the Hopkins rationale to protect men displaying stereotypically feminine traits, but several courts in a variety of contexts and with varying degrees of directness have rejected such claims.

4. I shall throughout this Article continue to refer to men who are seen as manifesting characteristics conventionally coded feminine as "effeminate" and not simply "feminine." This is in part because the word "effeminate" is used as something like a term of art in the case law and social science literature. More importantly, although I obviously deplore the negative valuation implicit in the term, it reflects a cultural reality I find unwise to ignore even in choice of terminology. Thus, the lack of parallelism between the terms "masculine woman" and "effeminate man" accurately mirrors the relative value placed in our society both on the respective qualities and on the persons manifesting them. 
One might propose that "gender" be added to "sex" as a prohibited basis for discrimination. This would in some respects be analogous to the inclusion of both "race" and "color." For reasons I shall explain, I do not propose that this be done. Instead, I argue that, at least under Title VII, the existing statutory language and doctrinal categories, if correctly applied, already provide the necessary protection to both effeminate men and feminine women, as well as their masculine counterparts. As to the requirement that employees conform their gender to their sex merely for the sake of such conformity-that women be feminine and men masculine-this is already outlawed by the plain language of Title VII as well as by the prohibitions on sex stereotyping outlined by the Supreme Court. It is impermissible disparate treatment. Thus, shocking though it may be to some sensibilities, not only masculine women such as Hopkins, but also effeminate men, indeed even men in dresses, should already unequivocally be protected under existing law from discrimination on the basis of gender-role-transgressive behavior. As to categorical discrimination on the basis of gendered characteristics-the requirement by an employer that, for example, all those in a certain job, regardless of sex, display stereotypically masculine traits-this, too, is open to challenge under existing doctrine. Discrimination against the feminine is likely to have a disparate impact on women, who are disproportionately likely to be feminine and not masculine; it should be permitted only if job-related and justified by business necessity. Men discriminated against for displaying feminine characteristics should also have standing to raise such claims. ${ }^{5}$

In seeking to shape a space for gender in the law and theory of sex discrimination, $I$ am arguing not so much for a change in the law as for a reconceptualization of the existing law, the cases that apply it to gender questions, and the issues presented by such cases. This Article will thus seek to demonstrate that a wide variety of cases and fact patterns not generally seen to have much to do with one another can all be better understood if organized for purposes of analysis under the rubric of gender; these include cases involving sex-specific clothing regulations, stereotypically feminine behavior by both men and women, sexual harassment of both women and men, jobs seen to require either predominantly masculine or predominantly feminine traits, single-sex education, sexual orientation, and transsexuality. To say that I do not primarily urge a change in the law is not to say that my analysis is intended to be of merely academic interest, however. Rather, my hope is that it may assist, not just scholars, but litigators, judges, employers, and policymakers confronted by the situations presented in these cases to structure their responses to them so as to realize more fully the goals of liberty and equality of the sexes already embodied in the law.

5. For a summary of how this would all play out, see infra Table 1 . 


\begin{tabular}{|l|l|l|l|l|l||}
\hline & $\begin{array}{c}\text { SEX OF } \\
\text { EMPLOYEE }\end{array}$ & $\begin{array}{l}\text { GENDER OF } \\
\text { EMPLOYEE }\end{array}$ & GENDER OF JOB & $\begin{array}{l}\text { EMPLOYER } \\
\text { DEMAND }\end{array}$ & $\begin{array}{l}\text { ANALYSIS \& RESULT } \\
\text { UNDER TrTLE VII }\end{array}$ \\
\hline 1 & Female & Masculine & $\begin{array}{l}\text { Masculine (e.g., } \\
\text { accountant) or } \\
\text { none }\end{array}$ & $\begin{array}{l}\text { Act more } \\
\text { femininely }\end{array}$ & $\begin{array}{l}\text { Disparate treatment: } \\
\text { Price Waterhouse v. } \\
\text { Hopkins }\end{array}$ \\
\hline 2 & Male & Feminine & $\begin{array}{l}\text { Feminine (e.g., } \\
\text { nursery school } \\
\text { teacher) or none }\end{array}$ & $\begin{array}{l}\text { Act more } \\
\text { masculinely }\end{array}$ & $\begin{array}{l}\text { Disparate treatment: } \\
\text { result governed by } \\
\text { Hopkins: impermissible } \\
\text { sex stereotyping }\end{array}$ \\
\hline 3 & Female & Feminine & $\begin{array}{l}\text { Masculine (e.g., } \\
\text { commission } \\
\text { salesperson) or } \\
\text { none }\end{array}$ & $\begin{array}{l}\text { Act more } \\
\text { masculinely }\end{array}$ & $\begin{array}{l}\text { Disparate impact: } \\
\text { once employee shows } \\
\text { that requiring masculine } \\
\text { or disfavoring feminine } \\
\text { qualities has disparate } \\
\text { impact on females, who } \\
\text { are disproportionately } \\
\text { feminine and not } \\
\text { masculine, employer } \\
\text { must then show that } \\
\text { requiring masculine or } \\
\text { disfavoring feminine } \\
\text { characteristics is job- } \\
\text { related and consistent } \\
\text { with business necessity }\end{array}$ \\
\hline 5 & Male & Feminine & Masculine & $\begin{array}{l}\text { Act more } \\
\text { masculinely }\end{array}$ & $\begin{array}{l}\text { Ius tertii claim, raising } \\
\text { argument made by } \\
\text { feminine womar in row } \\
\text { 3 above }\end{array}$ \\
\hline
\end{tabular}

Notes:

l"Act more femininely" is here a shorthand for, e.g., the advice given Ann Hopkins to "walk more femininely, talk more femininely, dress more femininely, wear make-up, have [your] hair styled, ... wear jewelry" and go to "charm school." 490 U.S. at 235 (1989).

${ }^{2} \mathrm{Or}$ act less femininely. Both phrases are shorthand for the reverse of the advice given Hopkins, e.g., take off your makeup and jewelry, cut your hair short and go to assertiveness training class.

TABLE 1. ANALYSis of GendeR DisCrimination Claims Under TrtLe VII 
The next two parts of this Article provide the theoretical underpinnings for the discussion of case law and doctrine that follows. Part II defines the terms I shall be using throughout the Article, explaining how gender and sex came to be conflated in the language of the law, why it is important to distinguish between them, and what relationships they can be seen to have to one another and to sexual orientation. Part III more fully explores the concept of gender; it makes use of scholarship from a variety of disciplines, including psychology, sociology, history, and musicology, to examine the component parts of gender, masculinity and femininity, and how they are perceived and valued. The central themes that emerge from this interdisciplinary look at gender are implicit as well in the case law. Among them are that gendered characteristics are often bundled; that things seen as masculine are often more highly valued than those seen as feminine, at least in part because the latter are associated with women; and that a woman exhibiting masculine characteristics is today viewed, both descriptively and normatively, quite differently from a man who exhibits feminine ones. Part III also begins the analysis of the various sex/gender combinations whose treatment by the law will form the core of this Article-masculine men, masculine women, feminine women, and effeminate men.

Part IV forms the centerpiece of my discussion of gender discrimination in the Title VII case law. Subsection IV.A.1 begins with a thorough exposition of the Hopkins case, from which much of the rest of my analysis of gender discrimination derives. It argues that Hopkins marks the third of four generations of sex-stereotyping cases: the first focused on the assumption that an entire sex conformed to gender stereotypes; the second on the assumption that individual members of the sex did; and the third on individuals penalized because their gender behavior did not conform to stereotypical expectations. Fourth-generation stereotyping claims, of the sort I endorse in this Article, might take on the stereotyping of the job and its requirements rather than of the person holding or applying for it-challenging the assumption that qualities gendered masculine (or, more rarely, feminine) are essential to success rather than demanded merely by stereotypical expectations.

The remainder of Part IV applies the lessons of Hopkins to the entire spectrum of gender discrimination under Title VII. Together, these sections explore all portions of Hopkins's double bind and the legal implications of the various ways it might be dissolved. Hopkins, recall, was caught between two inconsistent employer demands-that she be masculine to do her job and simultaneously feminine to conform to the role deemed appropriate for her sex. One way of dissolving the doubleness of this bind is by requiring only that one's gendered behavior conform to that deemed appropriate for one's sex. This occurs when men are required simply to be masculine, whatever 
their job may be, and is the situation of most effeminate men, as discussed in Subsection IV.A.2, as well as of most men who violate sex-specific grooming codes by wearing feminine attire to work, as discussed in Subsection IV.B.2. These men, I argue, are clearly protected by both the plain language of Title VII and the holding in Hopkins. If their employer tolerates feminine behavior or attire in women but not in them, the employer is subjecting them to disparate treatment in violation of Title VII. Another way of dissolving the double bind is for an employer to require of all employees regardless of sex that they manifest the gendered behavior associated with their job. This is the situation of many feminine women in conventionally masculine jobs, as discussed in Subsection IV.B.3, and should, I argue, be analyzed for its disparate impact by sex and permitted only if job-related and consistent with business necessity.

Subsection IV.A.2 forms the core of my discussion of the legal treatment of effeminate men. In it I compare the treatment of Ann Hopkins with that of two effeminate men in earlier cases. I argue that there is no basis in law for treating their cases differently from hers, although the culture certainly views them as quite different.

Subsection IV.B. 1 continues the examination of the legal treatment of effeminate men. In it I begin by explaining why, notwithstanding the tendency to conflate effeminacy and homosexuality in males, discrimination against effeminate men should not be seen as a mere subset of discrimination on grounds of sexual orientation. By examining the similarity of the taunts typically hurled at both women and gay or effeminate men in hostile environments, taunts that stress the feminine sexual passivity of all three groups, I then argue that the sexual harassment inflicted on all three groups may have in common the desire of certain "active" masculine males to drive out of the workplace those they see as contaminating it with the taint of feminine passivity. Such harassment is, therefore, a form of gender discrimination against the feminine, one with serious effects on the job performance and security of its victims, who should have a legal remedy against it regardless of their sex.

In Subsection IV.B.2, I expand on my claim that sex-specific grooming codes violate the plain language of Title VII and are inconsistent with the Hopkins holding. I discuss as well why it is important to those feminists who wish to see feminine styles more generally valued, rather than gradually eliminated as they may be in an androgynous culture slanted toward the masculine, that the protections of Title VII be seen as extending even to men in dresses. It is my contention that, unfortunately, the world will not be safe for women in frilly pink dresses-they will not, for example, generally be as respected as either men or women in gray flannel suits-unless and until it is made safe for men in dresses as well. I also, however, acknowledge the 
risks in insisting that employers impose the same grooming standards on men and women: Haunted by the specter of a man in a dress, employers may choose to impose a unisex, conventionally masculine grooming code on all employees; this would not only further reduce employee liberty but also further reinforce the supremacy of masculine standards and the decline of the feminine.

Subsection IV.B.3 explores the extent to which masculine standards of appearance and behavior are already in place in the work force. It focuses on the last of Ann Hopkins's potential alter egos, the feminine woman whose employer demands that she be more masculine on the job, and it notes the uneven success such women have had in getting their claims of sex discrimination accepted by the courts.

Part V sets forth somewhat more fully my vision of how the concept of gender discrimination is and should be incorporated in the law. I explain why I do not favor adding "gender" to the other prohibited forms of discrimination in the text of statutes like Title VII and how existing disparate treatment and disparate impact doctrine already has a place for claims of gender discrimination. Although I acknowledge the administrative difficulties some gender discrimination claims may pose, I go on to argue that nevertheless providing a remedy for these claims is crucial to ending the sex discrimination prohibited by Title VII. Using the example of proposed reforms in the Los Angeles Police Department (LAPD), I then suggest how voluntarily correcting for certain forms of gender discrimination may work to the advantage of an employer by improving the performance of employees. The reforms in the LAPD, prompted not so much by concerns about sex discrimination as by investigation into the Rodney King incident, were the result of asking whether the masculine qualities long seen as necessary in a police officer really were desirable on the job. The independent Christopher Commission concluded that feminine rather than masculine qualities were most conducive to good policing. As a result, it now appears likely that Los Angeles, by seeking out candidates with these qualities, will increase both the number of women and the overall performance of its police force. The experience of the LAPD, I contend, provides a model for non-litigious remedies for some forms of gender discrimination.

In the final part of this Article, I consider briefly some of the uses the conceptual disaggregation of sex and gender might have in contexts beyond Title VII, for feminist legal theory more generally and for the constitutional law of sex discrimination. My vehicle for doing this is an examination of two recent cases challenging as violative of the Fourteenth Amendment the continued exclusion of women from two state-sponsored military colleges, the Virginia Military Academy (VMI) and The Citadel. The facts of these cases starkly raise the issue at the core of this Article: Central to the litigating 
posture of both schools has been a refusal to contemplate any disaggregation of sex and gender. And central to any disposition of these cases is the sameness/difference question at the core of much of constitutional sex discrimination law and of feminist theory: To what extent does sex equality require sameness of treatment for the two sexes, or, alternatively, what sorts of differences between the sexes may serve as the basis for requiring or permitting what sorts of differences in treatment? Because the differences most at issue in the cases are gender differences, I suggest that viewing these cases under the rubric of gender discrimination may be particularly helpful for both law and theory. The VMI and Citadel cases offer the Court an important opportunity to clarify its sex discrimination jurisprudence by squarely facing the question of "the legal relevance of sex stereotyping": Is it now clear under the Constitution, as the Hopkins decision declares it to be under Title VII, that "we are beyond the day when [a decision-maker] could evaluate [individuals] by assuming or insisting that they matched the stereotype associated with their group"? " In forbidding "discriminat[ion] against individuals because of their sex," is the Constitution, like Title VII, "intended to strike at the entire spectrum of disparate treatment of men and women resulting from sex stereotypes" ${ }^{8}$ Finally, at the risk of sounding like one who claims to have found the philosophers' stone of feminist jurisprudence - a way out of the sameness/difference dilemma-only to wind up with fool's gold, I shall use an analysis of the way in which the VMI case falsely assumes a perfect identity of sex and gender and a near-perfect dichotomy of masculine and feminine in its effort to produce somewhat androgynous future citizen-soldiers to suggest that a separate analytic category for gender discrimination may indeed help point a way beyond sameness and difference.

\section{ON TERMINOLOGY: GENDER IS FOR ADJECTIVES, SEX IS FOR NOUNS}

The approach taken by Ruth Bader Ginsburg to the litigation of constitutional sex discrimination cases in the 1970s stands as both a hindrance and an inspiration to this Article. Ginsburg's work serves as an inspiration because, in both theory and practice, she has consistently espoused the inclusion of men in the work of feminism. ${ }^{9}$ In ways consistent with my aims in this Article, Ginsburg appeared to be both genuinely concerned about men and willing to use them to advance the cause of women. As one of the

\footnotetext{
6. Price Waterhouse v. Hopkins, 490 U.S. 228, 251 (1989).

7. Id.

8. Los Angeles Dep't of Water \& Power v. Manhart, 435 U.S. 702, 707 n.13 (1978) (quoting Sprogis v. United Air Lines, 444 F.2d 1194, 1198 (7th Cir. 1971)).

9. See, e.g., Ruth Bader Ginsburg \& Barbara Flagg, Some Reflections on the Feminist Legal Thought of the $1970 s, 1989$ U. CHI. LEGAL F. 9, 11.
} 
premier litigators of Supreme Court sex discrimination cases in the 1970s, Ginsburg often represented male plaintiffs, pointing out that laws based on stereotypical assumptions about the sexes hurt both women and men who violate these assumptions. ${ }^{10}$

Ginsburg's work is, however, a hindrance because she was in large part responsible for the fact that the words "sex" and "gender" are now used interchangeably in the law, creating what I shall argue is an unfortunate terminological gap. According to Ginsburg, "[f]or impressionable minds the word 'sex' may conjure up improper images" of what occurs in porno theaters." Therefore, she

stopped talking about sex discrimination years ago.... [S]he explained that a secretary once told her, "I'm typing all these briefs and articles for you and the word sex, sex, sex, is on every page. Don't you know those nine men [on the Supreme Court], they hear that word and their first association is not the way you want them to be thinking? Why don't you use the word 'gender'? It is a grammatical term and it will ward off distracting associations."12

Whatever advantages it may have in warding off embarrassment or salacious thoughts in the minds of judges, this interchangeability of the words "sex" and "gender" has contributed to some analytic confusion between the categories of male and female, on the one hand, and masculine and feminine, on the other. To help clear this up, I would urge a return to the distinction between the concepts of sex and gender as commonly defined by scholars in women's studies. As most feminist theorists use the terminology, "sex" refers to the anatomical and physiological distinctions between men and women; "gender," by contrast, is used to refer to the cultural overlay on those anatomical and physiological distinctions. While it is a sex distinction that

10. By challenging laws whose focus is a married couple, four of the cases Ginsburg argued before the Supreme Court make particularly plain the harm to both sexes from embodying stereotypical assumptions about sex roles in the law. Thus, in Frontiero v. Richardson, 411 U.S. 677 (1973), the presumption that a wife but not a husband was a dependent of a military spouse denied benefits to both the female soldier and the man she married. And in three cases involving the legal treatment of widowers, the most direct harm from the law's differential treatment of men and women fell on the men who were denied benefits. Nevertheless, the stereotyping on which the laws were based not only may harm women generally, but specifically reduced a wife's ability to provide for her surviving spouse. See Califano v. Goldfarb, 430 U.S. 199 (1977) (mandating Social Security benefits for widowers as well as widows); Weinberger v. Wiesenfeld, 420 U.S. 636 (1975) (mandating survivors' benefits regardless of whether deceased wage-earner was male or female); Kahn v. Shevin, 416 U.S. 351 (1974) (upholding against Ginsburg's client tax break for widows but not widowers). Wiesenfeld, in particular, provides a model for my aims in this Article, since, inter alia, it provides legal protection to men who bend gender roles, specifically by taking on the conventionally feminine task of caring for their own young children.

11. Ruth Bader Ginsburg, Gender in the Supreme Court: The 1973 and 1974 Terms, 1975 SuP. CT. REV. 1,1 n.1.

12. Ernie Freda, Washington in Brief: Clinton's Old Underwear Full of Tax Holes, ATLANTA J. \& ConsT., Dec. 29, 1993, at A8. 
men can grow beards and women typically cannot, it is a gender distinction that women wear dresses in this society and men typically do not. ${ }^{13}$

In urging that the distinction between sex and gender be maintained in the language of the law, I find myself, unusually, in some agreement with both Justice Scalia and Richard Epstein. Scalia noted in a recent opinion that he would refer to "sex" rather than "gender" discrimination because "[t]he word 'gender' has acquired the new and useful connotation of cultural or attitudinal characteristics (as opposed to physical characteristics) distinctive to the sexes. That is to say, gender is to sex as feminine is to female and masculine is to male."14 According to Scalia, the case then before him, involving the prosecution's elimination by peremptory challenge of all males from a jury in a paternity suit, "does not involve peremptory strikes exercised on the basis of femininity or masculinity (as far as it appears, effeminate men did not survive the prosecution's peremptories). The case involves, therefore, sex discrimination plain and simple." 15

My agreement with Epstein on the subject of terminology is far less complete. Although Epstein, too, has repeatedly insisted on using the word "sex" rather than "gender" when discussing antidiscrimination law, this is because according to Epstein:

Gender, when used as applied to nouns, carries with it a somewhat arbitrary appearance. . . . The clear implication, therefore, is that once we shift from sex, which is not arbitrary, to gender, which may be, we have strengthened the case for thinking gender differences irrelevant in all social contexts. From there it is a shorter step to Title VII's prohibition against discrimination on the ground of sex. ${ }^{16}$

It seems that Epstein objects to the terminological substitution in large part because, as a fan of sociobiology, he assumes that sex and gender are necessarily closely related. ${ }^{17}$ I object because I assume the opposite: There can be, I would contend, a world of difference between being female and being feminine. ${ }^{18}$

13. Of course, the boundary between sex and gender is contested, but it shouldn't matter much for present purposes.

14. J.E.B. v. Alabama ex rel. T.B., 114 S. Ct. 1419, 1436 n.1 (1994) (Scalia, J., dissenting).

15. Id.; cf. Goodman v. Lands End Homeowners Ass'n, No. 91-2542, 1992 U.S. App. LEXIS 9814 (4th Cir. May 6, 1992) (sustaining peremptory challenge of black male juror deemed "very effeminate" after district court had expressed doubt that this was justifiable, but ruled that not liking "the way that juror appears from a masculine vs. feminine standpoint" was sufficient race-neutral ground).

16. Richard A. Epstein, Gender Is for Nouns, 41 DEPAUL L. REV. 981,982 (1992).

17. See id. at 983-86; Richard A. Epstein, Two Challenges for Feminist Thought, 18 HARV. J.L. \& PUB. PoL'y 331 (1995). But see Mary Anne Case, Of Richard Epstein and Other Radical Feminists, 18 HARV. J.L. \& PUB. POL'Y 369 (1995).

18. I do not here claim that the relationship between sex and gender is wholly arbitrary. Rather, the questions of the "naturalness" of femininity in females and of the extent to which, even after a feminist revolution, women would still, on average, be more feminine and men more masculine than their opposite sex counterparts, are not ones on which I need take any position at all for present purposes. 
Thus, while Epstein insists that "gender is for nouns," 19 , on the contrary, am of the view that gender is for adjectives, sex is for nouns. Among the adjectives conventionally coded masculine are "aggressive," "ambitious," "analytical," "assertive," "athletic," "competitive," "dominant," "forceful," "independent," "individualistic," "self-reliant," "self-sufficient," and "strong." 20 These are the sorts of adjectives both Ann Hopkins's supporters and detractors used to describe her. Because these adjectives come straight out of the masculinity scale of one the most influential psychological inventories in sex-role research, they are by definition judged to be more desirable in American society for a man than for a woman. ${ }^{21}$

I do not "thin[k] gender differences irrelevant in all social contexts."22 It is in part because gender differences, unlike sex differences, ${ }^{23}$ may not be

19. Epstein, supra note 16 , at 981 .

20. I take these adjectives from the list of masculine iterns on the Bem Sex-Role Inventory (BSRI), the most frequently used measure in sex-role research and the standard to which other tests are most often compared. See Sandra Lipsitz Bem, The Measurement of Psychological Androgyny, 42 J. CoNSULTING AND ClINICAL PSYCHOL. 155, 156-57 (1974); Ellen Lenney, Sex Roles: The Measurement of Masculinity, Femininity, and Androgyny, in MEASURES OF PERSONALITY \& SOCIAL PSYCHOLOGICAL ATTTIUDES 573, 582, 596-97 (John P. Robinson et al. eds., 1991). The BSRI's list of qualities coded feminine includes affectionate, cheerful, childlike, compassionate, flatterable, gentle, gullible, loyal, sensitive, shy, soft-spoken, sympathetic, tender, understanding, warm, and yielding. See Bem, supra, at 156-57. According to Bem, all of these qualities are deemed desirable, notwithstanding the inclusion of "flatterable" and "gullible" in the feminine column. Id. at 155 .

21. See Bem, supra note 20, at 157. Price Waterhouse partners or clients praised Hopkins for “"strong character" (corresponding to BSRI 16), "independence" (corresponding to BSRI 7), and "strong leadership qualities"” (corresponding to BSRI 25), Hopkins v. Price Waterhouse, 825 F.2d 458, 462 (D.C. Cir. 1987), and criticized her for being "“aggressive"” (corresponding to BSRI 46), "somewhat masculine"” (corresponding to BSRI 40), and "'macho," Price Waterhouse v. Hopkins, 490 U.S. 228, 235 (1989).

22. Epstein, supra note 16 , at 982.

23. Except, of course, for extraordinary jobs like wet nurse, sperm donor, or surrogate mother. Even for such jobs, however, I do not think it necessary or helpful to declare sex a bona fide occupational qualification (BFOQ) such as would allow an employer categorically to exclude members of one sex. See 42 U.S.C. $\$ 2000 \mathrm{e}-2(\mathrm{e})(1)$ (1988) (allowing an employer "[n]otwithstanding any other provision of [Title VII to] . . . employ employees . . . on the basis of . . . sex . . . in those certain instances where . . . sex . . . is a bona fide occupational qualification reasonably necessary to the normal operation of that particular business"). Rather, in line with the Supreme Court's notorious distinction between "women" and "pregnant persons," I would favor a sex-neutral job description even for those jobs that, in the ordinary course of things, can be filled only by members of one sex. Thus, I would require of wet nurses only that they be lactating, not that they be female. The fact that successful applicants would likely be "exclusively female" does not necessitate per se discrimination against males. See Geduldig v. Aiello, 417 U.S. 484 (1974), in which the Court held that it is not sex discrimination under the Equal Protection Clause to deny insurance benefits for pregnancy, stating:

While it is true that only women can become pregnant, it does not follow that every legislative classification concerning pregnancy is a sex-based classification ....

... The program divides potential recipients into two groups-pregnant women and nonpregnant persons. While the first group is exclusively female, the second includes members of both sexes.

Id. at 496-97 n.20; see also General Elec. Co. v. Gilbert, 429 U.S. 125, 135-36 (1976) (applying same analysis under Title VII). Similarly, I find it bizarre that sex is considered a BFOQ, in the interests of "authenticity or genuineness," for the job of actor or actress. See 29 C.F.R. $\$ 1604.2$ (a)(2) (1994). After all, the very essence of this job is to pretend to be something one is not. All that a producer should be allowed to require is that the pretense be convincing. Thus, it may be necessary that actors whose work will require full frontal nudity possess the requisite genitalia or a convincing facsimile, but for most other acting jobs, it is difficuit for me to see how sex can be determinative, as the careers of Divine and of the many actresses who played Hamlet, from Sarah Siddons on down, may attest. See, e.g., MARJORIE GARBER, 
irrelevant in the employment context that I want to keep the terminology clear. One might reasonably, for example, want a nurse or a flight attendant to display characteristics conventionally gendered feminine, such as being "understanding," "warm," "able to devote oneself completely to others," "gentle," "helpful to others," "kind," and "aware of others' feelings."24 This does not mean, however, that being female will thereby become a bona fide occupational qualification (BFOQ) for nurses, flight attendants, or others whose jobs may require qualities gendered feminine, ${ }^{25}$ any more than being male can today be a BFOQ for partnership in a Big Eight accounting firm. Nor, as I shall discuss at length below, does it mean that the way certain jobs are currently gendered-the preference of Sears, Roebuck for aggressive, tough-talking commission salespersons, ${ }^{26}$ for example-should necessarily survive challenge under Title VII's prohibitions on sex discrimination.

A final category that needs to be brought into the discussion is sexual orientation. In this society, sexual orientation is measured chiefly by the relationship the sex of the object(s) of one's sexual desire bears to one's own sex, i.e., whether the object(s) of one's desire are of the same or of a different sex than oneself. ${ }^{27}$ As I shall have occasion to discuss below, ${ }^{28}$ however,

VESTED INTERESTS: CROSS-DRESSING \& CULTURAL ANXIETY 37-40 (1992). Consider the sex discrimination claim by a male with proven job success impersonating a woman on a phone-sex line targeted at heterosexual men. His wife had told him in urging him to apply for the job that, because he knew what men wanted to hear, he could appear more authentic and more appealing to male callers than most females. Courtney Brenn, Man Who Was Raven's Sexy Voice on Phone Is Broke, Jobless, RENo GAZETTE-J., Mar. 5, 1992, available in LEXIS, News Library, Arcnws File; cf. Cook v. Babbitt, Emp. Prac. Dec. $(\mathrm{CCH}) \mathbb{4} 42,267$, at 75,237 n.19 (D.D.C. 1993) (holding that categorically barring women from portraying male soldiers in Civil war re-enactment at Antietam National Battlefield Park constitutes unconstitutional discrimination against women because government's interest in accuracy is limited to effectiveness of portrayal, and actual sex of participant is irrelevant). While I am not prepared categorically to oppose a BFOQ for sex, I believe that it will very rarely be necessary. For an example where the need for authenticity or genuineness may indeed make sex, and not just impersonating ability, a BFOQ, see Button v. Rockefeller, 351 N.Y.S.2d 488 (Sup. Ct. 1973) (upholding sex as BFOQ for undercover policewomen charged, inter alia, with investigating illegal abortion).

24. These, together with "emotional," constitute the eight-item femininity scale of Spence, Helmreich, and Stapp's 1974 Personal Attributes Questionnaire (PAQ). See Lenney, supra note 20, at 606.

25. See Diaz v. Pan Am. World Airways, 442 F.2d 385 (5th Cir. 1971) (striking down per se exclusion of males from job of flight attendant notwithstanding findings of fact to effect that job required characteristics gendered feminine and therefore few men would qualify).

26. EEOC v. Sears, Roebuck \& Co., 628 F. Supp. 1264 (N.D. Ill. 1986), aff'd, 839 F.2d 302 (7th Cir. 1988). In this notorious case, the EEOC unsuccessfully charged Sears with sex discrimination in the selection of commission sales personnel. Sears had constructed its commission sales jobs on conventionally masculine lines, hiring people with conventionally masculine personality traits (e.g., assertiveness) and interests (e.g., hunting) to sell predominantly masculine products ranging from men's clothing to heavy equipment. In response to the EEOC's largely statistical case, Sears introduced testimony by an historian as to women's gender-based lack of interest in the sort of jobs Sears was offering. Numerous works of feminist scholarship have analyzed the Sears case, and I shall have occasion to discuss them and it in greater detail. See infra text accompanying and following note 251.

27. While I see the force of the observation that it is culturally contingent that we define our desire primarily by the sex of its object rather than by other things-such as the age or number of our sex partners or the nature of our relationship to our partner(s) or the sexual practices in which we prefer to engage-I am generally going to take this as a given in our culture and not problematize it here. See EVE KOSOFSKY SEDGWICK, EPISTEMIOLOGY OF THE ClOSET 8-9, 24-27, 34-35 (1990).

28. See infra Part III. 
for much of Western history an important axis of sexual orientation was instead that of active/passive or penetrative/receptive. With this as the axis, women together with males who allowed themselves to be penetrated orally or anally were opposed and seen as subordinate to "active" penetrative males. To the extent "passivity" in a male was itself seen as effeminate or associated with other effeminate behaviors, and to the further extent that the sex of the person penetrated was seen as a matter of some indifference in defining the orientation of the "active" male, sexual orientation can thus be said to have once been constructed, as it is not generally in America today, on gender rather than on sex. ${ }^{29}$

One simple vision of sex, gender, and orientation sees them as coming packaged together such that once one is identified, all the rest are determined. ${ }^{30}$ So closely linked can the three be seen to be that some transsexuals seem to have felt it necessary to cut off their penises and construct vaginas in order to be gendered feminine-e.g., to wear dresses. ${ }^{31}$ Determining which is the easiest of the three to identify has always been more complicated. Studies show that young children have an easier time telling a boy from a girl when each is fully dressed in gender-stereotypical attire than when each is naked, ${ }^{32}$ but for us grown-ups today sex is the least

29. See Eva Cantarella, Bisexuality in the ANCiEnt World 112-13, 175-81 (Cormac Ó Cuilleanain trans., Yale Univ. Press 1992) (1988); George Chauncey, GaY New YoRK: GENDER, URBAN CULTURE, AND THE MAKING OF THE GAY MALE WORLD 1890-1940, at 15, 27-28 (1994); Michael L. Satlow, "They Abused Him Like A Woman": Homoeroticism, Gender Blurring, and the Rabbis in Late Antiquity, 5 J. HIST. SEXUALITY 1 (1994). For an argument that active/passive still is the fault line for sexual orientation as well as gender, see generally Francisco Valdes, Queers, Sissies, Dykes, and Tomboys: Deconstructing the Conflation of "Sex," "Gender," and "Sexual Orientation" in Euro-American Law and Society, 83 CAL. L. REV. 1, 56-71 (1995).

30. This has been called the "principle of consistency." Diane Richardson, Lesbian Identities, in THE THEORY AND PRACTICE OF HOMOSEXUALITY 111, 112 (John Hart \& Diane Richardson eds., 1981) (quoting BARBARA PONSE, IDENTITIES IN THE LESBIAN WORLD: THE SOCIAL CONSTRUCTION OF SELF 27 (1978)). "In keeping with this principle, a 'deviation' in sexual object choice and sexual identity will typically lead to assumptions about gender-role orientation and gender identity." Id.; see also Jantz v. Muci, 62 Fair Empl. Prac. Cas. (BNA) 1623, 1628 (D. Kan. 1991) ("Yet homosexuals remain the subject of significant and virulent stereotyping in modern society. Homosexuals are believed to be effeminate (if gay) or masculine (if lesbian), ... to proselytize children to homosexuality or indeed seek out children to molest, ... [and] to be mentally ill; stereotypes which are all demonstrably false."). Note that violating gender roles is here seen by the court to be on the same level as molesting children, a "virulent" stereotype; no distinction is made between them.

31. See, e.g., White v. Farrier, 849 F.2d 322, 327 n.2 (8th Cir. 1988) ("“The penis has to go now. I have a female gender identify [sic], genital mutilation may be the only key. I am tired of suffering. . . . I can't take this any longer. I am a woman and women do not live like men. Women have vaginas and wear dresses." (quoting memo from inmate to prison warden)). There is a sense, thus, in which some transsexuals may be stuck at the level of Bem's toddlers. See infra text accompanying note 32 . This is consistent with their own self-description, borne out by clinical evidence that their sense of gender dysphoria often dates to early childhood; it is also, interestingly, consistent with their treatment by the law. See, e.g., Doe v. Boeing Co., 846 P.2d 531 (Wash. 1993) (upholding employer's right to deny to preoperative but grant to postoperative transsexual permission to wear feminine attire to work); DIAGNOSTIC AND STATTSTICAL MANUAL OF MENTAL DisORDERS 532-34, 536 (4th ed. 1994) [hereinafter DSM-IV] (defining gender identity disorders).

32. See Sandra Lipsitz Bem, The Lenses of Gender: TRansforming the Debate on SeXual INEQUALITY 114 (1993). The results of these studies should hardly be surprising, since in diapered toddlers, sex is completely invisible. Indeed, in most of us most of the time, sex is only suggested to observers by 
problematized of these categories. ${ }^{33}$ How does one determine sex? Well, as in the old cartoon with the two toddlers peeking into their diapers, one looks down at the genitalia; ${ }^{34}$ alternatively one looks at the chromosomes: XY for males, XX for females. ${ }^{35}$ Once sex has been identified in the traditional vision, both gender and orientation can readily be determined-anyone with a vagina, for example, must wear a dress (i.e., be gendered feminine) and desire people with penises, who all wear pants, etc. Of course, for most of us the vision is no longer that simple. We have come to realize that the categories of sex, gender, and orientation do not always come together in neat

secondary sex characteristics and by gender, both of which can diverge from the genitalia or the chromosomes of the person manifesting them. It is as if-as my student Bianca Bennett has suggested-we were to divide the world based on belly-button shape into innies and outies. Although belly buttons, like genitalia, are generally invisible in fully clothed people, we might still assume that extroverts were outies and introverts innies.

33. But see Thomas Laqueur, Making SeX: Body and Gender from the GREeKs to Freud 149-92 (1990) (arguing that for much of Western history gender was seen as determinate, sex as malleable category).

34. The genital definition of sex appears to be the basis for the various state statutes permitting postoperative transsexuals to amend their sex "upon documentation that sex change surgery has been performed." Catherine Kunkel Watson, Comment, Transsexual Marriages: Are They Valid Under California Law?, 16 Sw. U. L. REv. 505, 506 (1986). To determine sex, one can look at chromosomes, internal and external genitalia, hormones, and gonads. Ulane v. Eastern Airlines, Inc., 742 F.2d 1081, 1083 n.6 (7th Cir. 1984).

35. This simple taxonomy is complicated by, among others, Anne Fausto-Sterling, whose study of various sorts of hermaphrodites-including those with chromosomal combinations such as XXY and $\mathrm{XYY}$-leads her to argue that there are at least five sexes, who are forced by the prevailing binarism into the prevailing two. Anne Fausto-Sterling, How Many Sexes Are There?, N.Y. TIMES, Mar. 12, 1993, at A29. Fausto-Sterling calls representatives of intermediate hermaphroditic sexes ferms, herms, or merms, depending on the balance of female and male characteristics. Id. I personally am inclined to see slicing sex that finely as either trivial and irrelevant (given the minuscule number of people in other than the two generally recognized sexes) or alternatively more troubling than liberating (risking the reinforcement of hierarchies such as the ever finer slicing of racial classifications from Black and White to quadroon and octoroon in antebellum Louisiana, or the distinction between Black, White, and Colored in South African apartheid law). Cf. Alex M. Johnson, Jr., How Race and Poverty Intersect to Prevent Integration: Destabilizing Race as a Vehicle to Integrate Neighborhoods, 143 U. PA. L. REv. 1595, 1605 (1995) (stating that "[i]ntegration will ensue when racial identification becomes fluid and contingent rather than fixed and definitive"). I am not out of sympathy with an effort to break down sexual binarism, just skeptical it can be done or that this is the way to do it. The case law has enshrined sexual binarism in its interpretation of the statutory language of Title VII prohibiting discrimination "because of sex." See, e.g., Ulane, 742 F.2d at 1085 (holding that discrimination against transsexuals is not sex discrimination within meaning of Title VII because "discrimination based on sex, in its plain meaning, implies that it is unlawful to discriminate against women because they are women and against men because they are men"); Wood v. C.G. Studios, Inc., 660 F. Supp. 176, 177 (E.D. Pa. 1987) (holding that discrimination against plaintiff because she had undergone surgery to correct her hermaphroditic condition was not discrimination on basis of sex because "[t] he plain meaning of the term 'sex', as it is used in the statute, would [only] encompass discrimination against women because of their status as females and discrimination against males because of their status as males"). 
packages. Not only are they not as binary as we might once have thought, ${ }^{36}$ they can in fact be disaggregated.

Indeed, the disaggregation of sex and orientation is conceptually wellnigh complete. It should by now come as no surprise to anyone in this culture, whatever his or her normative view of homosexuality, that being male does not necessarily fix one's sexual orientation toward females; there are unquestionably males who lust after other males, and we no longer tend to think of them as a "third sex" or an "intermediate sex" because of this tendency. ${ }^{37}$ Gender, by contrast, has not yet found a conceptual space all its own, for all that we are now disposed to acknowledge that not all women, nor all those attracted to men, behave in stereotypically feminine ways; nor are all those who behave thus female or attracted to males. ${ }^{38}$

My aim in the discussion that follows is to shape such a space for gender in the law and theory of sex discrimination. The relationships between and among gender, sex, and orientation have recently been the subject of much

36. Thus androgynes, hermaphrodites, and bisexuals have broken down the binarisms of masculine/ feminine, male/female, and gay/straight. For a discussion of the many "varieties of androgyny, see infra text accompanying and following note 60 . For the spectrum of sexual orientation, see, e.g., ALFRED KINSEY ET AL., Homosexual Outlet, in SEXUAL BEHAVIOR IN THE HUMAN MALE 610 (1948), reprinted in LESBIANS, GAY MEN, AND THE LAW 1 (William B. Rubenstein ed., 1993) (presenting Kinsey scale, ranging from zero to six, with heterosexuality and homosexuality at poles, perfect bisexuality in middle, and intermediate numbers describing those whose fantasies and/or sexual experiences focus predominantly, but not exclusively, on one or other sex). Interestingly, the scale was developed in research on males; when Kinsey later studied women, he found that a substantial percentage of them did not register anywhere on the scale because, within the relevant time period, they had neither fantasized about nor had sex with a person of either sex. Alfred KINSEY ET AL., Homosexual Responses and Contacts, in SEXUAL BEHAVIOR IN THE HUMAN FEMALE 446 (1953), reprinted in LESBIANS, GAY MEN, AND THE LAW, supra, at 14. Thus, just as measures of masculinity and femininity now distinguish between an androgynous person (strong in both masculinity and femininity) and an undifferentiated one (strong in neither), see infra note 44, so perhaps measures of sexual orientation-from those in scholarly research to those in antidiscrimination statutes-should leave room for a preference for none of the above, and include asexual as well as homosexual, heterosexual, and bisexual. But see, e.g., CAL. Civ. CoDE $\S 51.7$ (b) (West Supp. 1995) (defining "sexual orientation" to include only heterosexuality, homosexuality, or bisexuality). For arguments in favor of creating a discursive space in which sexual identity is not reduced to one or more binary oppositions, see, e.g., Katherine Franke, Cherchez La Femme: Law, Sexual Identity and Desire (delivered at conference on Direction and Distortion: The Centrality of Sexuality in the Shaping of Feminist Legal Theory, Columbia University, June 1994) (unpublished manuscript, on file with author).

37. See, e.g., CHAUNCEY, supra note 29, at 47, 49-63 (discussing theories of nineteenth-century gay intellectuals-such as Karl Ulrichs, Edward Carpenter, and Magnus Hirschfeld-who "claim[ed] that they were best characterized as a 'third sex' or an 'intermediate sex' . . hermaphroditically combining psychic qualities of both the male and female"); Valdes, supra note 29, at 56-71, 409-44. But see Cheryl M. McCormick \& Sandra F. Witelson, A Cognitive Profile of Homosexual Men Compared to Heterosexual Men and Women, 16 PSYCHONEUROENDOCRINOLOGY 459 (1991) (finding that with regard to certain cognitive measures, gay men occupy intermediate ground between straight men and straight women); see also infra Subsection IV.A.1.

38. There still is some tendency, however, even among some gay men themselves, to assume that effeminacy is correlated, not merely with male homosexuality, but with stereotypically feminine sexual behavior. See, e.g., Christopher Lonc, Genderfuck and Its Delights, in GAY ROOTS: TWENTY YEARS OF GAY SUNSHINE 223 (Winston Leyland ed., 1991). For an example of a statutory conflation of gender bending and sexual orientation-and possibly of transsexualism-see MINN. STAT. ANN. $\$ 363.01$ (West Supp. 1995) (defining sexual orientation, inter alia, as "having or being perceived as having a self-image or identity not traditionally associated with one's biological maleness or femaleness"). 
study and theorizing. ${ }^{39}$ But, while questions of gender and its relation to both sex and orientation permeate the case law of sex discrimination, the discussion of such questions in the cases is rarely marked by explicit acknowledgement or even implicit awareness of the analytic structures generated or the concerns raised in these theoretical discussions. Courts toss around the words "gender," "masculine," "feminine," and "sex stereotyping" fairly often in sex discrimination cases. But they do not always use these terms consistently or self-consciously, and they do not always recognize gender issues when such issues are presented. Courts often conflate gender with sex and particularly with sexual orientation, often without acknowledging and sometimes apparently without being aware that they are doing so. ${ }^{40}$ They occasionally seem oblivious to the fact that apparently disparate collections of behaviors and characteristics at issue in cases before them actually form a coherent gender package when analyzed together. ${ }^{41}$ And even when they do acknowledge that, for example, a set of characteristics an employer demands of employees can best be characterized as "masculine," they rarely subject to critical examination their own willingness or that of the employers in cases before them to equate the masculine with the good or desirable. $^{42}$

For this reason, before proceeding to analyze in depth the various sorts of cases that raise gender issues under Title VII, I have thought it best to

39. See, e.g., BEM, supra note 32; KATE BORNSTEIN, GENDER OUTLAW: ON MEN, WOMEN, AND THE REST OF US (1994); JUDITH BUTLER, BODIES THAT MATTER: ON THE DISCURSIVE LIMITS OF "SEX" (1993); JUDITH BUTLER, GENDER TROUBLE: FEMINISM AND THE SUBVERSION OF IDENITTY (1990); GARBER, sUpra note 23; JUDITH LORBER, PARADOXES OF GENDER (1994); MARTINE A. ROTHBLATT, THE APARTHEID OF SEX: A MANIFESTO ON THE FREEDOM OF GENDER (1995). For two recent and interesting examinations of sex, gender, and orientation in law that, unfortunately, reached me after I had substantially completed this Article, see Katherine Franke, The Central Mistake of Anti-Discrimination Law: The Disaggregation of Sex from Gender, 144 U. PA. L. REV. (forthcoming 1995) and Valdes, supra note 29. In a sense, Valdes, Franke, and I each center on a different apex of the triangle formed by sex, gender, and orientation. Valdes, who seeks to break down the confiation between the three as a step toward queer legal theory, takes sexual orientation as his apex; Franke seeks to break down the category of sex; I concentrate on gender. Although each of us is concerned with numerous aspects of what Valdes calls the conflation of sex, gender, and orientation, my focus is the gender bender; Valdes's, the homosexual; and Franke's, the transsexual. I am most grateful to both authors for sharing their drafts and their comments with me. For other notable recent works on the legal treatment of related issues, see Kathryn Abrams, Title VII and the Complex Female Subject, 92 MICH. L. REv. 2479 (1994); Katharine T. Bartlett, Only Girls Wear Barrettes: Dress and Appearance Standards, Community Norms, and Workplace Equality, 92 MiCH. L. REv. 2541 (1994); Andrew Koppelman, Why Discrimination Against Lesbians and Gay Men Is Sex Discrimination, 69 N.Y.U. L. REv. 179 (1994); Nancy Levit, Feminism for Men: Legal Ideology and the Construction of Maleness, 43 UCLA L. REV. (forthcoming 1996). I am grateful to Professors Bartlett, Levit, and Koppelman for sharing their work with me in advance of publication.

40. For an exhaustive analysis of this conflation, see generally Valdes, supra note 29. See also infra Subsection IV.A.2 (discussing Smith v. Liberty Mut. Ins. Co., 569 F.2d 325, 327 (5th Cir. 1978) and DeSantis v. Pacific Tel. \& Tel. Co., 608 F.2d 327 (9th Cir. 1979)).

41. See infra text accompanying notes 235-38 (discussing Wislocki-Goin v. Mears, 831 F.2d 1374, 1376 (7th Cir. 1987)).

42. See infra text accompanying notes $240-41$ (discussing Fadhl v. City \& County of S.F., 741 F.2d 1163 (9th Cir. 1984)); text accompanying notes 243-45 (discussing Zahorik v. Cornell Univ., 729 F.2d 85 (2d Cir. 1984)); text accompanying notes 298-308 (discussing Los Angeles Police Department). 
discuss gender theory in some detail, with reference to scholarship from a variety of disciplines. The central themes that emerge from this interdisciplinary look at gender are implicit as well in the case law. Among these themes are that gendered characteristics are often bundled; that what is seen as masculine is more highly valued than what is seen as feminine, at least in part because the latter is associated with women; that, in addition to being generally devalued, the feminine is viewed as completely unacceptable in males; and that a woman exhibiting masculine characteristics is today viewed, both descriptively and normatively, quite differently from a man who exhibits feminine ones. While none of these propositions may seem startling or controversial, I think it useful to begin by setting them forth explicitly and putting them in a theoretical context because they lurk beneath the surface of the cases discussed in the central portions of this Article. In addition, the following section serves as an introduction to the three polar sex/gender combinations around which I will organize much of my discussion of the case law of gender discrimination - the masculine woman, the effeminate man, and the feminine woman.

\section{HISTORY AND THEORY OF GENDER BENDING: HEREIN OF HIC MULIER AND HAEC VIR}

Contemporaneously with Ruth Bader Ginsburg's move to conflate sex and gender in the language of the law and with explorations by scholars of women's studies into the cultural contingency of gender, psychologists in the 1970s sought to map the parameters of masculinity and femininity in new ways. ${ }^{43}$ Their research suggested that masculinity and femininity could vary independently, rather than be reducible to a negative relationship with one another. ${ }^{44}$ Moreover, researchers began to challenge the assumption that

43. As one summary of such sex-role research put it:

Prior to the early 1970s, tests were built upon the assumption that masculinity and femininity were polar opposites having a necessarily inverse relationship within the individual. Such unidimensional devices, often called M-F tests, scored respondents who fell at one of the two extremes as either masculine or feminine and those who fell between the two extremes as having a given amount of the single entity M-F.

Although the prevailing bipolar view did not logically dictate that persons falling at different points along the M-F continuum would differ in the extent to which they possessed desirable attributes, such an idea seems to have been an inextricable part of most researchers' sex role conceptions. Appropriate sex-typing was seen as important for good adjustment and mental health, broadly construed. Thus, the masculine male and the feminine female were believed to be psychologically advantaged relative to their less sex-typed counterparts.

Lenney, supra note 20, at 575. For an influential review and critique of these early bipolar M-F tests, see Anne Constantinople, Masculinity-Femininity: An Exception to a Famous Dictum?, 80 PsYCHOL. BuLL. 389 (1973). For a review of studies calling into question the correlation between conformity to gender roles and psychological health, see BARBARA L. Forisha, SEX Roles aND PERSONAL AwARENESS (1978). For an early critique of the double standard for mental health, see Inge Broverman et al., Sex-Role Stereotypes and Clinical Judgments of Mental Health, 34 J. Consulting \& CLINICAL PSYCHOL. 1 (1970).

44. Thus, it began to be assumed possible for a single person to score high in both masculinity and femininity or, alternatively, to score low on both scales. Bem referred to the former sort of person as 
conforming gender to sex was most desirable or healthy. For one of the most influential of the new generation of researchers into sex roles, Sandra Lipsitz Bem, it was the combination of masculine and feminine qualities in the androgynous personality that was most conducive to success and happiness because it allowed one to adapt best to a wide variety of situations. ${ }^{45}$ This was very much in the feminist spirit of the times, ${ }^{46}$ although later research suggested as a descriptive rather than a normative matter that it was actually a strong absolute masculinity score, regardless of sex or of femininity score, that was most conducive to psychological well-being, ${ }^{47}$ perhaps because masculine traits are more culturally esteemed than feminine traits. ${ }^{48}$ As I shall discuss at length below, research also indicated that, in addition to psychological well-being, masculinity was associated with career success in both sexes and with desirable qualities in a wide variety of employment contexts, particularly for those jobs accorded high status and high pay in our society. ${ }^{49}$

When I discuss stereotypical masculinity and femininity in the course of this Article, I am not necessarily referring to these concepts as measured by any paper and pencil test. ${ }^{50}$ One of many respects in which the standard sex-

androgynous, the latter as undifferentiated. Although the tests in question are of psychologically-rather than physically-manifested masculinity and femininity, an analogy to icons of popular culture may help illustrate the difference between the androgynous and the undifferentiated. See BEM, supra note 32, at 120. Consider, on the one hand, Prince (whose new name, combining the traditional male and female symbols, is not accommodated by my keyboard) and, on the other hand, the Saturday Night Live character Pat, see MARJORIE GARBER, VICE VERSA: BISEXUALITY AND THE EROTICISM OF EVERYDAY LIFE 230-31 (1995) (discussing portions of JULIA SWEENEY \& CHRISTINE ZANDER, IT's PAT! MY LIFE EXPOSED (1992)). Pat notoriously is of indeterminate sex, yet we are thrown into confusion not because she sends out conflicting gender signals, but precisely because she seems to send out none at all-she is undifferentiated. Prince's androgyny, by contrast, is composed of strong signals of both masculinity and femininity in dress, gesture, voice production, etc.

45. See Bem, supra note 20 , at 155 .

46. Consider, for example, CARolyn G. HeIlbrun, TOWARD A RECOGNITION OF ANDROGYNY (1973), which insisted that

our future salvation lies in a movement away from sexual polarization and the prison of gender toward a world in which individual roles and the modes of personal behavior can be freely chosen. The ideal toward which I believe we should move is best described by the term "androgyny." This ancient Greek word-from andro (male) and gyn (female)-defines a condition under which the characteristics of the sexes, and the human impulses expressed by men and women, are not rigidly assigned. Androgyny seeks to liberate the individual from the confines of the appropriate.

1d. at $\mathrm{ix}-\mathrm{x}$.

47. See, e.g., Derek Grimmell \& Gary S. Stern, The Relationship Between Gender Role Ideals and Psychological Well-Being, 27 SEx RoLes 487, 487-88 (1992) (reviewing prior literature on advantages of masculine traits, although suggesting that degree to which "participants' gender-specific traits represent met or unmet ideals is a better predictor of psychological adjustment than personal gender role alone").

48. See Hope Landrine, Depression and Stereotypes of Women: Preliminary Empirical Analyses of the Gender-Role Hypothesis, 19 SEX ROLES 527, 527-29 (1988).

49. See Paul T.P. Wong et al., On the Importance of Being Masculine: Sex Role, Attribution, and Women's Career Achievement, 12 SEx RoLes 757, 757 (1985).

50. The two most widely used tests, the BSRI (Bem Sex-Role Inventory) and the PAQ (Personal Attributes Questionnaire) designed by Spence and Helmreich, are both of 1970s vintage. Both were constructed to measure masculinity and femininity as perceived by persons in this culture, rather than any essential, universal, or eternal qualities. Bem sought to identify qualities viewed as more desirable in one 
role inventories are less than true to life is that they cannot differentiate between various forms of masculinity, femininity, and androgyny. None purports to measure all gendered characteristics. Indeed, most confine themselves, not only to personality traits, but further to a single axis such as one equating masculinity with instrumental, self-assertive traits and femininity with expressive, affiliative traits. ${ }^{51}$

Of course, this highlights the difficulty with using single terms to cover a wide range of culturally coded behaviors ranging from physical appearance to clothing and self-presentation, to personality and attitude, and to patterns of speech and behavior. ${ }^{52}$ Consider, for example, the following physical manifestations of gender as a complement to the psychological ones sex-role inventories seek to measure. Gender in our culture is marked by differences

sex than in the other, although desirable in both. See Lenney, supra note 20 , at 588, 590-91. The PAQ sought to cover some personality traits desirable in both sexes but believed to be possessed by one sex more than by the other (designated $M$ or $F$ ) as well as some characteristics whose desirability was believed to vary depending on sex (designated M-F). See id. at 599. In describing these tests in such detail, it is not my intention to endorse their validity or the gender schema they purport to describe. In fact, the construction of the tests is, in my view, quite open to criticism. For example, the component items of the BSRI have not been altered since it was created by surveying not more than 100 Stanford undergraduates as to their views as to the desirability of traits by sex. See Bem, supra note 20, at 156-59.

51. Thus, the designers of the PAQ specifically stated that it was meant to measure "not global masculinity, but self-assertive-instrumental traits; and not global femininity, but interpersonal-expressive traits." Lenney, supra note 20 , at 598. Bem acknowledged, "In general, masculinity has been associated with an instrumental orientation, a cognitive focus on 'getting the job done'; and femininity has been associated with an expressive orientation, an affective concern for the welfare of others." Bem, supra note 20 , at 156.

The self-assertive/instrumental traits that are central to tests explicitly designed to measure masculinity are virtually identical to those measured by tests such as the "Active" and "Vigor" dimensions of the Thurstone Temperament Schedule, by which applicants for commission sales jobs at Sears were measured. It is therefore understandable that the profile of the commission sales person set forth in Sears's Retail Testing Manual "was unmistakeably masculine." Ruth Milkman, Women's History and the Sears Case, 12 FEMINIST STUD. 375, 382 (1986). The district court's description fits Milkman's characterization:

According to the manual, a good commission salesperson possesses a lot of drive and physical vigor, is socially dominant, and has an outgoing personality and the ability to approach easily persons they do not know. ... . IIn reviewing applications . . . managers and interviewers look for... any special training, education, or experience indicating an active, outgoing personality. ... . During the interview, managers looked for a number of important qualities, including aggressiveness or assertiveness, competitiveness, the ability to communicate effectively, persuasiveness, an outgoing, social or extraverted [sic] personality, self-confidence, personal dominance, a strong desire to earn a substantial income, resilience and the ability to deal with rejection, a high level of motivation and enthusiasm for the job, maturity, and a good personal appearance.

EEOC v. Sears, Roebuck \& Co., 628 F. Supp. 1264, 1290 (N.D. Ill. 1986). See infra text accompanying notes 249-51 for further discussion.

52. Nevertheless, such terms have been held legally cognizable, on something akin to an "I know it when I see it" basis. For example, a military court overruled objections to testimony describing a man as "effeminate" by explaining:

No extended period of observation or particular expertise is required for a layman to detect patent effeminacy in the actions and mannerisms of a member of the male sex. However, while a witness might be able to describe certain overt, unquestionably feminine gestures, more subtle behavioral nuances of this nature would defy description. Thus, effeminacy in a man may be considered to be one of those matters which, although commonly experienced, are usually not adequately conveyed to the court by a mere recitation of the facts observed by the witness.

U.S. v. Yeast, 36 C.M.R. 890, 902 (A.B.R. 1966); cf. Jacobellis v. Ohio, 378 U.S. 184, 197 (1964) (Stewart, J., concurring) (saying of obscenity, "I know it when I see it"). 
in voice (femininity is associated with high-pitched voices, at best soft-spoken, at worst shrill; masculine voices are louder and deeper); gesture (femininity is associated with grace, gentleness, tentativeness, and deference; masculinity is physically more bold, aggressive, and decisive; it takes up more space in a room ${ }^{53}$ ); clothing ${ }^{54}$ and personal appearance (femininity is associated with pastel or bright colors, above all with shades of pink, with frills, ruffles, and soft fabrics, ${ }^{55}$ with skirts and dresses. Masculinity is more drab and practical: its paradigm may still be the gray flannel suit; it generally is free of ornaments such as jewelry, makeup, and long or elaborate hair styles) ${ }^{56}$ One might argue that jewelry and frilly clothes are merely the superficial indicia of our gendered lives and that a far more important marker of the feminine is, for example, being the primary caregiver for one's child. Not only jobs in the workplace, but tasks in the home (breadwinner vs. caregiver, mowing the lawn vs. ironing, work with hammer and nails vs. needle and thread), hobbies (hunting vs. knitting), and children's toys (guns vs. dolls, according to a Newsweek cover story ${ }^{57}$ ) have been pervasively gendered. ${ }^{58}$ Students of everything from speech patterns to lawyering styles have argued that they are also gendered. ${ }^{59}$ For all that these various gendered characteristics were once seen as a package deal, our more

53. See Sallie Tisdale, The Weight that Women Carry: The Compulsion to Diet in a Starved Culture, HARPER's, Mar. 1993, at 49, quoted in ELLEN LUPTON, MECHANICAL BRIDES: WOMEN AND MACHINES FROM HOME TO OFFCE 52 (1993) ("Furniture designers distinguish between a man's and a woman's chair, because women don't spread out like men.").

54. On the gendering of clothing styles, see ANNE HolLANDER, SEX AND SUITS (1994). Consider the often-remarked-upon sexual dimorphism of birds, where it is characteristically the male who displays bright colors and elaborate plumage to a comparatively drab female.

55. One can extend this analysis of colors, fabrics, and accessories from the person to the surroundings. Thus a masculine room is furnished in dark woods and hunter green, a feminine one in floral print chintz. See, e.g., LUPTON, supra note 53, at 31-35 (describing gendering of machines and household objects, such as princess phone).

56. While I would hesitate to sum up contemporary visions of masculinity or femininity in a single pair of words, I might if pressed say that femininity is generally associated with softness and masculinity with hardness. This seems at least an improvement in both accuracy and value-neutrality over the more traditional pairing of weakness and strength, although it retains two features still open to some question-the sense that the two are incompatible opposites and the danger of a too facile equation of gender with sex differences.

57. Laura Shapiro, Guns and Dolls: Scientists Explore the Differences Between Boys and Girls, NEWSWEEK, May 28, 1990, at 56.

58. This is a different but related observation to the one that these tasks have been predominantly performed by one or the other sex. As with being soft-spoken in the BSRI, so with cooking or sewing in the household-it is seen as both more prevalent among and more desirable for females than males in this society. (I do not mean to suggest that it is therefore any longer seen as unacceptable or undesirable for males to perform these tasks.)

59. See, e.g., DEBORAH TANNEN, You JUST DON'T UNDERSTAND (1990) (arguing that men and women use different styles of communication); Carrie Menkel-Meadow, Portia in a Different Voice, 1 BERKELEY WOMEN's L.J. 39 (1985) (discussing gendered lawyering). Researchers often describe feminine speaking styles as marked by indirection, tentativeness, and discursiveness. Instructions distributed by the University of Virginia hospital to postoperative male-to-female transsexuals suggest that in order to be more convincingly feminine they should not interrupt others and should use self-deprecating qualifiers when speaking. I am grateful to Pat Gill for drawing these instructions to my attention. 
androgynous society has found them mixed and matched in virtually unlimited combinations and degrees of intensity. ${ }^{60}$

While I cannot hope to sketch out all the permutations of sex and gender, I do think it important to note that they are more complicated than established measures of sex roles or gender schemas may suggest. I have therefore attempted to set forth in three figures some sense of the complexity of gender. ${ }^{61}$ Figure 1 charts the simple bipolar view of masculinity and femininity as opposites, with any decrease in one necessarily representing an increase in the other. As noted above, for most researchers adopting such a schema, the best place for one to be was toward the pole conforming gender to sex-masculine men and feminine women were seen as better off than gender benders, although it is also likely that masculine men were seen as better than feminine women.

$\underset{\text { (masculine) }}{\text { ANDRO }}$ (feminine)

FIGURE 1.

Figure 2 maps Bem's vision of masculinity, femininity, and androgyny, with the $\mathrm{Y}$-axis representing masculinity and the $\mathrm{X}$-axis femininity. The point with coordinates $(0,0)$ thus represents the perfectly undifferentiated person ${ }^{62}$ and the line marks androgyny, for Bem the socially desirable outcome, descriptively and normatively. True to our cultural norms, I have drawn the line of acceptable androgyny far closer to the masculine than to the feminine axis. This reflects the fact that "our culture conceives of power as power used by men, and creates androgynous models 'tilted' toward the male. As Carrie Menkel-Meadow put it, the trouble with marble cake is that it never has enough chocolate; the problem with androgyny is that it never has enough womanness." ${ }^{163}$ Thus, every aspect of such androgyny as is fashionable today

60. A woman today can top her long tresses with a baseball cap or her flattop with a bow. She can talk tough and look delicate or vice versa. She can bring home the bacon and fry it up in a pan. In each case, she can be seen to combine elements of the stereotypically masculine with elements of the stereotypically feminine for a more or less socially acceptable, more or less androgynous result, but the combinations are very different. I use a woman in the above examples advisedly. As I shall argue, women have been far freer to assimilate the traditionally masculine in our present culture than men have been to engage in behaviors traditionally gendered feminine. For example, I am hard pressed to think of a single article of attire that $I$ would now feel uncomfortable wearing because it was excessively masculine. (Of course, some combinations of masculine items may still result in a total look deemed unacceptable in a woman.) Nor are many behaviors coded so masculine that they are viewed as appropriate in men and inappropriate in women-smoking a pipe may be among the few that might so much as raise an eyebrow.

61. Even in these figures, though, I cannot hope to depict the multidimensionality of gender. Thus, it is clearly not the case that each point on any of the graphs represents a unique combination of gendered traits.

62. See supra note 44 .

63. Christine A. Littleton, Reconstructing Sexual Equality, 75 CAL. L. REv, 1279, 1302 (1987) (footnotes omitted) (citing Carrie Menkel-Meadow, Address at the 15th National Conference on Women 
is constructed by women's taking a giant, culturally-endorsed step toward the masculine, while men move, if at all, only a baby step toward the feminine. ${ }^{64}$

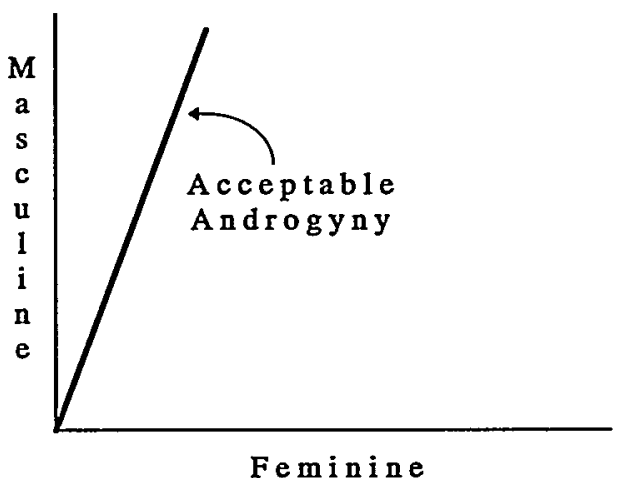

FIGURE 2.

Figure 3 represents my own attempt at complicating Bem's schema. Bem, as noted, has so perfectly disaggregated sex and gender that her test does not measure gender (i.e., masculinity or femininity) by reference to sex at all. ${ }^{65}$ Consistent though this assumption may be with Bem's normative preferences (indeed, with some of my own), I fear that it does not reflect current cultural reality. The same degree of masculinity and femininity is read quite differently in a man and in a woman, as Ann Hopkins learned to her cost. ${ }^{66}$

and the Law (Mar. 31, 1984)).

64. Women today are found in the work force, in pants, and in the outfield far more often and with far less comment than men are found in the nursery, in dresses, or in ballet class. It is, many cultural critics would argue, no accident that the very word "androgyny" begins with the Greek word for male.

65. Bem's scoring system takes no account of the sex of the subject, making no distinction between a masculine woman and a masculine man, although men, on average, not surprisingly tend to have higher masculinity scores than women. See Bem, supra note 20, at 158, 160-61.

66. For another practical application of the question of whether the same raw masculinity score has different effects in a man and a woman, as well as of the connection between gendered psychological traits and other gendered behaviors, consider once again Sears's psychological testing of commission sales applicants. One test

measured seven dimensions of temperament. On six of them, there were few differences between female and male scores, but on the seventh, the Vigor scale, there were dramatic differences. The reason is evident from the twenty questions comprising the Vigor scale, which included the following: "Do you have a low-pitched voice?" "Do you swear often?" "Have you ever done any hunting?" "Have you participated in wrestling?" "Have you participated in boxing?" "Have you played on a football team?" The EEOC presented evidence that Sears believed that "a woman who scored 9 on the Vigor scale would have the same behavior as a man who scored 14." But while the company's 1973 "Retail Testing Manual" set out different recommended Vigor scores for selecting women and men for many other jobs, it used the same standard for both sexes in its recommended scores for commission sales positions. According to the manual, a man scoring 14 would be considered to have a "best score," while a woman scoring 9 would be viewed as a poor risk-even though Sears believed their behavior would be the same.

Milkman, supra note 51, at 382. See infra text accompanying notes 288-89 for further discussion. 
The direction in which the lenses of gender distort our reading of others' manifestation of stereotypically gendered traits may vary, but, in my experience, one of the things that causes our readings to vary is the sex of the person manifesting the gendered characteristics. ${ }^{67}$

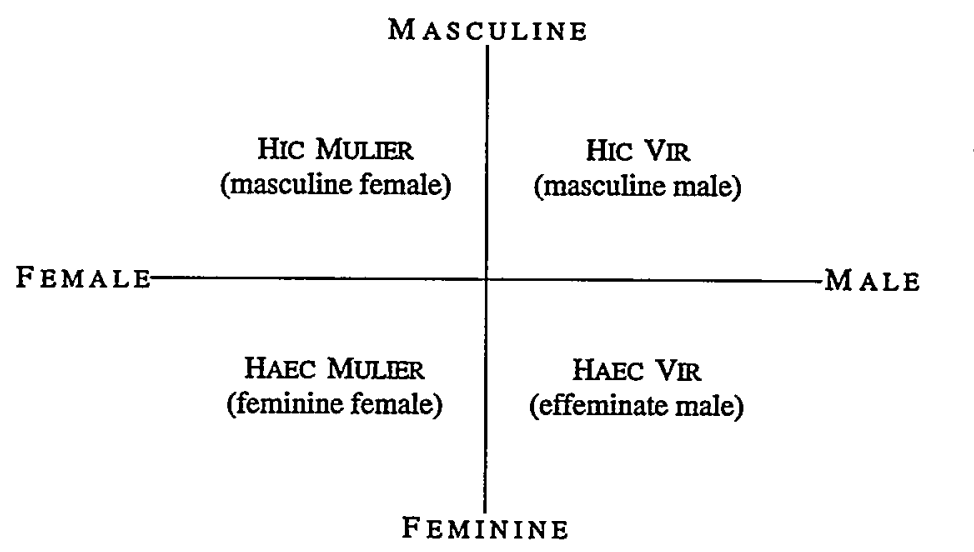

FIGURE 3.

In shifting to a more complicated map of gender, ${ }^{68} \mathrm{I}$ have also shifted from Greek to Latin. The term androgyny, of course, comes from the Greek words for male and female. I have here substituted their Latin equivalents,

67. Moreover, as my figure intends to suggest, sex as well as gender in this culture may be read as on a continuum, not simply on/off, male/female. Although there remains, in my view, a bright-line distinction between male and female, the presence and intensity of secondary sex characteristics may subtly influence our perception of another's sex, quite apart from his or her gender. There is little sense in denying, for example, that a brawny, balding, bearded, six-foot-four-inch man will be read as male even in a frilly dress and with delicate mannerisms (i.e., gendered feminine), as television commercials featuring cross-dressed athletes may demonstrate. Because he simply cannot pass as a woman, such a man's adoption of feminine traits will work very differently than it would were he physically as well as psychologically and in manner androgynous. He will be read as more unequivocally male than someone slight, smoothcheeked, and diminutive with identical dress and mannerisms. That this may (but does not necessarily) mean that he will be read as more masculine points up the extent to which the sex of the subject influences our reading of his gender. Similarly, a woman with an hourglass figure cannot help but be read as female no matter how masculine her affect. Perhaps for this reason, transsexuals seem to give substantial attention to the alteration of secondary sex characteristics-female-to-male transsexuals often grow beards as well as have mastectomies; male-to-female ones often have electrolysis and facial plastic surgery, as well as hormonal treatments.

68. While Figure 3 becomes more complicated through the addition of sex, it does lose, at least in a two-dimensional version, Bem's insight that masculinity and femininity are not reducible to a single continuum. In some respects, this is unfortunate; in others, however, it appears more accurately to reflect current constructions of masculinity and femininity. For, while the two may not bear a perfectly inverse relationship with each other, neither can they be seen as completely independent. A cursory examination of the qualities included on modern inventories of masculine and feminine traits reveals several that are close to polar opposites-for example, yielding and assertive, or gentle and aggressive. In arguing that masculinity and femininity could vary independently, Bem insisted only that individuals "might be ... both assertive and yielding, both instrumental and expressive-depending on the situational appropriateness of these various behaviors." Bem, supra note 20 , at 155 . 
"Vir" and "Mulier." To identify the masculine woman and the effeminate man respectively, I have used the terms "Hic Mulier" and "Haec Vir." These terms are formed by combining the noun referring to one sex with the intensifying adjective proper to the other. A rough translation might be He-woman and She-man. ${ }^{70}$ I use the combination Haec Vir and Hic Mulier-the noun for male with a feminine adjective and the noun for female with a masculine adjective-to reinforce my claim that gender is for adjectives, sex is for nouns; that is to say, gender is the adjectival overlay on sex. ${ }^{71}$ But I do not invent these terms; I take them from a pair of early seventeenth-century British pamphlets ${ }^{72}$ debating proper behavior and proper attire for men and women and, in particular, fulminating against gender bending, as much an issue in Jacobean England ${ }^{73}$ as it is today.

69. Among my reasons for doing this is that the etymology of these words and the English words that derive from them reconfirms many of the claims made in this Article. Just as "vir" is associated with "virtue" and "virtuosity," so too, masculine qualities are both more highly esteemed and viewed as more universally desirable: The masculine and the good are quite literally equated. "Mulier," on the other hand, is derived from "mollus"- soft or weak. These are qualities not generally viewed as desirable, although they have their moments of favor. "Mulier" is associated not only with English words like "mollify," but with the Latin term for passive homosexuals. See CANTARELLA, supra note 29, at 112-13 (describing Roman condemnation of those who in homosexual relations took "a subordinate position like a woman"; these passive homosexuals were referred to as "molles" or "soft"). In the late Empire they were to be burned alive; transvestites were also subject to punishment and disapproval. Id. at 175-81.

One dictionary defines "masculine" as follows: "adj. 1. of or having to do with men; male. 2. like a man; manly; strong; vigorous . . . 3. having qualities, tastes, etc. suited to a man; mannish: [for example,] a masculine woman." THE WORLD BOOK DICTIONARY 1191 (1967). The definition of "male" adds that "[m]ale, masculine, manly mean having to do with men or the sex to which they belong. Male applies to plants, animals, or persons, and suggests only sex .... Masculine applies to persons, things, or qualities, and suggests the characteristics (especially strength, vigor, etc.) of man as distinguished from woman . . . . Manly suggests the finer characteristics of man, such as courage and honor . ..."Id. at 1175.

The same source defines "feminine" and "effeminate" as follows: feminine, "adj. 1. of women or girls; ... carried on by women . . . 2. like a woman; womanly; weak; gentle: [for example,] feminine sympathy or intuition. 3. like that of a woman; not suited to a man; womanish; effeminate; weak." Id. at 726; effeminate, "adj. 1. lacking in manly qualities; showing weakness or delicacy that is not manly. . . [from] Latin ... effeminare make a woman of." Id. at 627.

Note that even in these definitions, the masculine is opened up without comment to women ("a masculine woman") while the feminine is defined as "not suited to a man." Note also that the paradigmatic masculine and feminine qualities are, respectively, strength and weakness, as they have been at least since the Romans.

70. Or, to continue the Saturday Night Live imagery, one might refer to Hic Vir as Hans and Franz's "manly man," Haec Vir as their "girly man," with the womanly woman and the manly woman (in Latin, "virago," which in modern English signifies both harridan and heroine) rounding out the picture.

71. Of course, again, the current trend among theorists is to call into question the stability or fixity of sex, to claim it may be just as malleable and performative as gender. See, e.g., JUDITH BUTLER, BODIES THAT MATTER (1993).

72. HiC MULIER: OR, tHE MAN-WOMAN: BENG A MEdicine to CURE THE COLTISH DiSEASE OF THE STAGGERS IN THE MASCULINE-FEMININES OF OUR TIMES, EXPREST IN A BRIEF DECLAMATION (The Scholar Press Limited 1973) (1620); HAEC-VIR: OR, THE WOMANISH-MAN: BEING AN ANSWERE TO A LATE BOOKE INTTTULED HIC-MULIER; EXPREST IN A BRIEFE DIALOGUE BETWEENE HAEC-VIR THE WOMANISH-MAN, AND HIC-MUlieR THE MAN-WOMan (The Scholar Press Limited 1973) (1620). Note the subtle distinction between the Womanish-man and Man-woman: Does androgyny once again permit more of a move toward the masculine? Note also the two forms, declamation and dialogue. See generally Mary Anne Case, From the Mirror of Reason to the Measure of Justice, 5 YALE J.L. \& HUMAN. 115, 120 (1993) (explaining nature and common topics of declamations).

73. The year 1620, when Hic Mulier and Haec-Vir were first published, was less than twenty years after Elizabeth I, who insisted that she "ha[d] the body of a weak and feeble woman, but . . . the heart and 
The junior versions of Hic Vir and Haec Mulier are children engaged in the gendered behavior deemed appropriate for their sex. In the United States today, some of the same androgyny favored by adults is prevalent among children. ${ }^{74}$ But we still have words for the junior versions of Hic Mulier and Haec Vir, words that have become virtual terms of art in the psychological literature- "tomboy" and "sissy." Tomboys are far more acceptable and unproblematic today than are sissies, ${ }^{76}$ who, it is still feared, are at a high risk of growing up to be homosexual or transsexual ${ }^{77}$ and for whom clinical

stomach of a king," was succeeded by the weak and effeminate James I. GARBER, supra note 23, at 28 (citing PAul Johnson, Elizabeth I: A STUDY IN POWER AND INTEllect 320 (1974)). Although sumptuary laws were repealed in the reign of James $I$ and unisex styles were the rage,

James, notoriousiy bisexual and extravagant, . . . was phobic about powerful women-and about women in men's clothes. In 1620 he instructed Anglican clergy "to inveigh vehemently in their sermons against women wearing broad-brimmed hats, painted doublets, short hair, and even some of them poniards, and, if pulpit admonitions fail, another course will be taken."

Id. at 31 (quoting 10 CALENDAR OF STATE PAPERS, DOMESTIC, JAMES I, at 116, reprinted by Kraus Reprint (Allen B. Hinds ed., 1970)). Meanwhile, Puritan preachers invoked the Deuteronomic prohibitions on cross-dressing to rail against gender bending, sodomy, and the theater. Id. at 29.

74. Notably, little girls are wearing pants and playing actively, although fewer little boys are playing dress-up or with dolls. But see Scott LaFee, Toying with Idea of Gifts Marketed for Gender, SAN DIEGO UNION TRIB., June 4, 1994, at E1. A boy and a girl alternately playing pirates and neighbors together was what Carol Gilligan described as androgyny. Gilligan preferred the new game suggested by the girl, who told the boy, "'you can be the pirate who lives next door," thus combining the two games into one that "arises through the relationship" and transforms the discourse. See Ellen C. DuBois et al., Feminist Discourse, Moral Values, and the Law-A Conversation, 34 BUFF. L. REV. 11, 45 (1985) (comments of Carol Gilligan).

I was struck on a recent visit to Russia how much more thoroughly than in the United States young children there are gendered. Even as preschoolers, little girls there seem all girl, little boys all boy. Not only do the girls there wear frilly dresses, great big bows atop their long braids, gold earrings in their pierced ears, and nail polish, but they also appear to have learned to simper and act shy or coquettish, while the boys strut.

75. See, e.g., Richard Green, The "Sissy Boy SYNdrome" AND THE Development of HomoseXUALITY (1987). The third edition of the Diagnostic and Statistical Manual of Mental Disorders added to its list of Psychosexual Disorders, "Gender Identity Disorder of Childhood," which was, the manual insisted, "not merely the rejection of stereotypical sex role behavior as, for example, in 'tomboyishness' in girls or 'sissyish' behavior in boys ... . " AMERICAN PSYCHIATRIC ASSOCIATION, DiagnostiC AND STATISTICAL MANUAL OF MENTAL DiSORDERS 264 (3d ed. 1980) [hereinafter DSM-III]. But the diagnostic criteria focused precisely on such behavior in addition to "profound disturbance of the normal sense of maleness or femaleness." Id.

76. [B]y twenty to twenty-four months of age, preschool children generate much more restrictive gender rules for their male peers than for their female peers, an asymmetry for which there is no obvious source in either cognitive development or biology but for which there is an obvious source in the culture, which prescribes much harsher treatment for male gender deviants ("sissies") than for female gender deviants ("tomboys").

BEM, supra note 32 , at 114 . It is not only children, but adults who enforce these distinctions; adults are far more worried about gender bending by boys and men than by women and girls. $C f$. Fudge v. Penthouse Int'l, 840 F.2d 1012, 1016 (1st Cir. 1988) (rejecting libel claim by girls identified as "amazons" in photograph caption, because "[t]here is a sufficiently wide spectrum of reasonable opinion as to what constitutes appropriate gender-correlated behavior for schoolgirls that it would be impossible to prove the truth or falsity of the statement that the girls are "masculine women,"' one allegedly defamatory definition of "amazons").

77. See, e.g., Eve KosofsKy SEDGWICK, How to Bring Your Kids Up Gay: The War on Effeminate Boys, in TENDENCIES 154, 157 (1993) ("A American psychiatry is simply engaged in a long, subtle process of reconceptualizing homosexuality as a mental illness with another name-the "gender identity disorder of childhood."') (quoting Lawrence Mass, Sissyness as Metaphor: A Conversation with Richard Green, 


\section{treatment is more often prescribed. ${ }^{78}$ This is further evidence of the disproportionate pull of gender-masculinity in a girl is approved while femininity in a boy is not only troublesome, but a marker for homosexual orientation. $^{79}$}

1 HomoseXUALITY \& SEXUALITY 213, 214 (1990)). According to DSM-IV, about three-quarters of boys who have a childhood history of Gender Identity Disorder report a homosexual or bisexual orientation but without concurrent gender identity disorder. DSM-IV, supra note 31, at 536.

I do not endorse any conflation of gender bending and homosexuality myself. Rather, I think that introducing the element of sexual orientation into the Figure 3 schema further complicates it. As many theorists have noted, adding the element of orientation can both destabilize and reinforce the traditional gender categories. One might readily see Hic Mulier and Haec Mulier as the butch/femme couple, with the butch the masculine, and the femme the feminine, half of a rigidly gendered lesbian pair. That conventional butch and femme styles have everything to do with gender presentation and not necessarily with sexual behaviors narrowly defined can be seen in the phrase "butch in the streets, femme between the sheets." See,

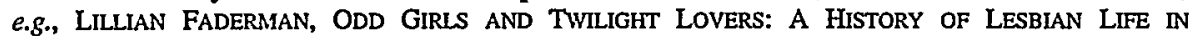
TWENTIETH-CENTURY AMIERICA 263-68 (1991) (discussing use and reformulation of masculine and feminine stereotypes in butch/femme culture). Moreover, even if a butch remains butch between the sheets, this, as theorists have noted, by no means makes her masculine. On the contrary, while the stone butch, who refuses to be touched herself, may see herself as stereotypically masculine because she takes the active, assertive role in sex, she can just as readily be seen as the epitome of what Robin West calls the feminine giving self, who gets pleasure from her partner's pleasure. See Robin L. West, The Difference in Women's Hedonic Lives: A Phenomenological Critique of Feminist Legal Theory, 3 WIS. WOMEN's L.J. 81 (1987).

Compare the gender role schemas (instrumental/affiliative) in the psychological tests described above. If overlaying issues of sexual orientation onto this schema makes the butch the manly woman and the femme the womanly woman, who are the manly and the effeminate gay man? The answer may differ depending on which aspects of gender presentation one focuses on. Thus, one might see the two respectively as "trade" and "fairy." See, e.g., CHAUNCEY, supra note 29, at 65-70 (describing earlytwentieth-century urban subculture in which "fairies" (self-identified passive homosexuals effeminate in dress and manner) competed with female prostitutes and "tough girls" for sexual attentions of "trade" (masculine men who took active role in sex but were somewhat indifferent as to the sex of their partners)). Alternatively, they may be seen as the drag queen and the clone. While the world of the drag queen is extravagantly feminine, clone culture is one of hypermasculinity. The former's apparel features sequins, feather boas, and false eyelashes, set off by graceful gestures; the latter features closely cropped hair, black jeans, and a t-shirt hugging a muscular body. Like the butch/femme couple, the drag queen and the clone paradigmatically exaggerate stereotypically gendered appearance and behavior. Trade and fairies, divided in part along an active/passive axis, may, by contrast, track masculinity and femininity in behavior rather than appearance. For an extended theoretical discussion of what gender bending in a homosexual context may say about the relationship between sex, gender, and orientation, see JUDITH BUTLER, GENDER TROUBLE 123 and generally (1990).

78. According to DSM-IV:

In child clinic samples, there are approximately five boys for each girl referred with this disorder. In adult clinic samples, men outnumber women by about two or three times. In children, the referral bias toward males may partly reflect the greater stigma that cross-gender behavior carries for boys than for girls.

DSM-IV, supra note 31 , at 535.

79. According to one man who as an adult embraced the term "sissy":

For lack of any adequate pre-existent terminology ... . I will follow the lead of lesbians who call themselves "dykes" and the militant gay rights group, "Queer Nation", and I will seize a pejorative term that was hurled at me and other such males, and I will make it my own: "sissy". The word is etymologically derived from "sister" and therefore directly connotes the sense of being like a girl or woman. Although this male-centered world tends to emphasize the worst of feminine characteristics, such as dependency and passivity, and the best of masculine ones, such as taking initiative and having courage, femininity is also associated with nurturing, caring, and being sensitive, while masculinity is also associated with violence, vulgarity and an obsession with winning and dominating. A sissy is a male (regardless of sexual orientation) who is in some way not masculine, who is in some meaningful way more like women than men tend to be, or are "supposed" to be. Maybe he is proud of it. Maybe he has reasons for not wanting to 
In Figure 3, as, I believe, in contemporary perception, the masculine woman and the effeminate man are read as polar opposites, rather than as identical or approaching one another. ${ }^{80}$ One way of illustrating the extent to which a man displaying stereotypically feminine characteristics is read differently from a woman displaying masculine ones is by considering the example of the human voice-inflected by sex, but also gendered, ${ }^{81}$ and gendered in a way that further shows the extent to which feminine characteristics are devalued relative to masculine ones, to the detriment not only of men displaying those feminine characteristics but of women generally. While a relatively deep voice is a male secondary sex characteristic, both men and women can to some extent control the pitch of their speaking voice to conform to gendered or other role expectations. In this society, however, high-pitched voices are generally read as both feminine and out of favor, while deep voices are associated with a wide range of desirable qualities, from authority to sexiness. Not only does a countertenor risk being despised as unmanly, ${ }^{82}$ but virtually the only circumstance in this society in which a

resemble other males in personality and behavior. In my case, I certainly am, and do.

To say "regardless of sexual orientation" is to threaten an assumed connection, a bond which is so rarely challenged that it is rarely recognized as such. When I was being called "sissy", I was also being called "faggot" and "queer" as I was being physically and verbally assaulted. To be a sissy is to be on the inside of homophobia .... You don't even have to be physically attracted to males to get in.

Allan Hunter, Same Door, Different Closet: A Heterosexual Sissy's Coming-out Party, in HETEROSEXUALITY 150, 152-53 (Sue Wilkinson \& Celia Kitzinger eds., 1993).

80. As noted above, some view the masculine woman and the feminine man as identical. It is certainly true that one variant of androgyny in our culture bears this out. Consider, for example, the gamin(e). But for the kinds of gender bending at issue in most of the cases herein discussed, this is not the case. Ann Hopkins was not seen as androgynous, but as too masculine, the polar opposite rather than the identical twin of effeminate men such as Bennie Smith of Smith v. Liberty Mutual. See infra text accompanying and following note 162 .

81. Thus, a countertenor and a Broadway belter, the Haec Vir and Hic Mulier of the music world, may hit exactly the same notes, but their voices will produce opposite impressions-his feminine, though male, hers masculine, though female. As Will Crutchfield, music critic for the New York Times puts it:

Vocal registers in the classical sense are the two basic categories of sound that the human

voice can produce: male and female. Each sex is capable of both kinds of sound . . . .

....

The classical terms for these registers ... are "chest voice" and "head voice" ... . [or] "falsetto"....

... [C]ountertenors sing in nearly unmixed falsetto throughout their ranges. These countertenors are precise opposite numbers to Broadway's "belters"--women who sing exclusively in the "male" register of chest voice. The range is almost identical.

Will Crutchfield, That Strange Breed of Singer, Countertenors, N.Y. TIMES, Sept. 25, 1988, at H27, H36.

Not only would no one confuse the voice of Alfred Deller with that of Ethel Merman, see id., the styles of both belters and countertenors have become more closely associated with the gender ascribed to their voice than with the sex of the person producing it. According to Crutchfield, "in the broader historical context, it might be better to describe [falsetto] as representing the feminine within the male (just as, conversely, the assertive brashness of chest voice can be heard as representing the masculine within the female)." Will Crutchfield, The Falsetto Enjoying New-Found Attention, N.Y. TIMES, Mar. 16, 1987, at C15 [hereinafter Crutchfield, The Falsetto]. Falsetto thus typically appears at moments when male singers are expressing romantic tenderness or "nurturing solicitude-typically thought of as 'female' characteristics, but ones that men might share, just as they share the possibility of singing in head voice." Id.

82. Crutchield, The Falsetto, supra note 81 , at $\mathrm{C} 15$. 
woman is advantaged by a high-pitched voice is when she auditions for a role as a soprano. This is not, however, simple sex discrimination in that men with high-pitched voices are also at some disadvantage-in the employment market, ${ }^{83}$ in court, in politics, ${ }^{84}$ and elsewhere. Indeed, it is likely that a woman will fare better than a man with the same pitch, because her voice will be heard as comparatively low for her sex, his as comparatively high. This does, however, highlight the extent to which the interplay of sex and gender, and the disfavoring of characteristics gendered feminine, may work to the systematic detriment of women and thus should be analyzed as a form of sex discrimination. ${ }^{85}$

The example of the deep voice also points up the extent to which women in this society are, as a descriptive matter, moving closer to a masculine standard and, as a normative matter, are rewarded for so doing. Researchers have confirmed that as women have moved into the work force and into positions of authority over the last half century, the pitch of their speaking voices has also dropped considerably. According to speech pathologist Cecilia Pemberton, who compared recordings of women speaking from 1945 and 1993, "[t] the difference is enormous ... [; ] the pitch of the current 1993 women is much lower.... [T] [Te women you heard in 1945 portrayed a

83. One of the questions Sears asked applicants for commission sales jobs was: "'Do you have a lowpitched voice?"' EEOC v. Sears, Roebuck \& Co., 628 F. Supp. 1264, 1300 n.29 (N.D. I1l. 1986) (quoting Thurstone Temperament Scale).

84. Thus, both Margaret Thatcher and George Bush were coached to deepen their voices and avoid sounding shrill. See Michael Kramer, Saying Bye-Bye to the Wimp Factor, U.S. NEWS \& WORLD REP., Nov. 9, 1987, at 46; Vikki Orvice, Why 90s Women Are Lowering Their Tone, DaILY MAIL (London), Apr. 14,1993 , at 8 .

85. Implicit in this analysis is the assumption that deep voices are favored at least in part because they are associated with males, not simply because there is something inherently more valuable about a deep voice. If deep voices are associated with authority, for example, this may have much to do with the fact that most authority figures have been men and we have therefore grown accustomed to hearing authority with a male voice. See CATHARINE A. MACKINNON, Difference and Dominance: On Sex Discrimination, in FEMINISM UNMODIFIED 32, 36 (1987). The EEOC's expert in the Sears case, Dr. Siskin, referred to the difficulty of telling whether particular characteristics serve as a proxy for sex as "proxy bias." According to Siskin's testimony:

[A]lthough it may appear from the analysis that a particular characteristic possessed disproportionately by males, such as automobile experience . ... is associated with success, in fact it may only reflect that greater success of males in general, presumably due to discrimination. Thus, if there is in fact discrimination in favor of men, characteristics more commonly held by men would appear in the analysis to be more closely correlated with success than characteristics held by women.

Sears, 628 F. Supp. at 1298-99; see infra text accompanying note 260 and text accompanying and following note 320 .

Certainly in this instance the suggested line of causation is more plausible than one asserting that men achieved authority because of their deep voices. (Compare, by contrast, the possible lines of causation between male physical strength and male authority.) I do not mean to (nor need I for the purposes of my argument) assert that all of our preference for low voices is the product of illegitimate sexism, however. A complicating factor may be that another axis for high- and low-pitched voices is that of child and adult, with the adult's comparatively low-pitched voice conveying authority. 
much more "feminine" voice.' ... A lower-pitched voice [was] now associated with maturity and authority in women ...."

This leads me to posit that a change may be occurring in the hierarchical ranking, in life and in law, of the variously sexed and gendered components of Figure 3. Hic Vir's place at the top of this hierarchy is clearly established. It has almost always been viewed as best for almost all purposes to be a masculine man. ${ }^{87}$ The effeminate man, by contrast, seems still generally to occupy a lower rung on the hierarchy. ${ }^{88}$ What change there has been has come in the relative value placed, in a variety of contexts, on the feminine and the masculine woman. The former was previously seen as the epitome of womanliness, which was highly valued in its place-as angel of the domestic sphere, for example, or as ministering angel by the sickbed. Certain jobs

86. Researchers Get the Low-Down on Women's Voices, Reuters, Apr. 13, 1993, available in LEXIS, News Library, Arcnws File. Speech analyst Catherine Charlton agrees: "High-pitched voices are now perceived as child-like, indecisive, unreliable and weak. If a woman speaks like this at work it is difficult for her to be taken seriously. So, they have quite simply taken on a much more male voice." Orvice, supra note 84 , at 8 . Both experts associate the change in women's voices with the change in their role in society. See id.; see also Feminine Voices Lose Their Lilt, S. ChINA MORNING POST, June 4, 1993, at 17 (summarizing Pemberton's study).

87. See MACKINNON, supra note 85 , at 36 . While it has under most circumstances been more advantageous to be masculine as well as male, there are exceptions. Those gendered feminine usually do worse and occasionally do better-often they are the victims, but occasionally they are the beneficiaries of societal preferences. See, e.g., Diaz v. Pan Am. World Airways, 442 F.2d 385 (5th Cir. 1971) (holding that legitimate preference for characteristics gendered feminine in flight attendants cannot justify per se ban on hiring males).

88. As an editorial in the 1920 s heyday of Rudolph Valentino put it, "Better a rule by masculine women than by effeminate men." Pink Powder Puffs, CHI. SUNDAY TRIB., July 18, 1926, at A10, reprinted in GARBER, supra note 23, at 361-62. This editorial associated effeminacy in men with a wide variety of dangerous social trends, from pacifism to communism to criminality and lawlessness.

Treating those who move down in a hierarchy, whether of race, class, or gender, with greater disfavor than those who seek to move up appears to have been a constant in Western history. More particularly, the move downward, when not seen as purely parodic, was consistently seen as both dangerous and sexualized. See, e.g., Vern L. Bullough \& BonNIE Bullough, Cross DREsSING, SEX, AND GENDER 46 (1993); Vern L. Bullough, Transvestism in the Middle Ages, in SEXUAL PRACTICES \& THE MEDIEVAL CHURCH 43, 45 (Vern L. Bullough \& James A. Brundage eds., 1982). As Vern L. Bullough explains:

A female who secretly wore men's clothes was not considered abnormal. That a female might desire to be a male, in fact, seemed to be a healthy desire, a normal longing not unlike the desire of a peasant to become a noble. . . . Though men might dress as women at carnivals, and the lord might mix with the peasants at various festivals, the status loss in any real change along these lines was so threatening that anything more than play acting was forbidden.

Vern L. Bullough, Transvestites in the Middle Ages, 79 AM. J. SoC. 1381, 1392 (1974). That an attempt by a member of the disfavored group to take on the characteristics of the favored group is viewed quite differently than is a move by a member of the favored group toward the disfavored one is apparent in the language conventionally used to describe such moves. Thus, one speaks of women passing as men, see infra note 90, as of Blacks passing as White, and one understands that they may do this for the serious purpose of improving their lot in the world, however much one may deplore their choice or the world that made it necessary. By contrast, Whites seem to take on the appearance of Blackness chiefly for parodic purposes-Whites don't pass as Black, they only put on blackface, as in a minstrel show. Similarly, the term "drag," though applicable to women in men's clothing, is more characteristically used to describe men in women's clothing. Not only drag queens, but virtually any men in women's clothing still excite remark and controversy, are viewed willy-nilly as parodic, and have great difficulty being taken seriously. For a discussion of the significance of the distinction between "passing" and "drag," see Mary Anne Case, Couples and Coupling in the Public Sphere: A Comment on the Legal History of Litigating for Lesbian and Gay Rights, 79 VA. L. REv. 1643, 1664 n.87 (1993). For further discussion of men in dresses, see infra Subsection IV.B.2. 
habitually held by women in this society even demanded feminine qualities from applicants and rejected those, especially males, who were seen to lack them. ${ }^{89}$ But the sphere available to feminine women was a restricted one. For most jobs, especially those offering high status and high pay, masculine qualities were seen as more desirable. What, then, of the masculine woman? In earlier times, she often actually had to pass as a man to gain access to such desirable jobs. ${ }^{90}$ More recently, however, both the cultural and the legal balance may have shifted in her favor. A case like Price Waterhouse $v$. Hopkins-indeed, much of the rest of sex discrimination law-protects her. ${ }^{91}$ It may now even perhaps be viewed as better to be a masculine woman than a feminine one. Thus, as in the psychological literature, so in the employment market and in the law, the axis of comparative desirability may have shifted from one favoring gender conformity to one favoring masculinity pure and simple, whether manifested by men or women.

This has been a source of consternation among feminist legal theorists, ${ }^{92}$ who have noted with varying degrees of outrage and regret that progress toward equal opportunity for women may have benefitted chiefly those

89. Successful discrimination suits by male plaintiffs helped open two such professions, those of nurse and flight attendant, to men. See, e.g., Mississippi Univ. for Women v. Hogan, 458 U.S. 718 (1982) (upholding right of male to study nursing at all-female, state-supported school under Equal Protection Clause); Diaz v. Pan Am. World Airways, 442 F.2d 385 (5th Cir. 1971) (upholding sex discrimination claim by males who were denied positions as flight attendants).

90. See JoNATHAN KATZ, GAY AMERICAN HiSTORY: LESBIANS AND GAY MEN IN THE U.S.A. 209-79 (1976) (documenting "passing women" from 1782 to 1920); The San Francisco Lesbian and Gay History Project, "She Even Chewed Tobacco": A Pictorial Narrative of Passing Women in America, in HIDDEN FROM HISTORY: RECLAIMING THE GAY AND LESBIAN PAST 183, 183-94 (Martin Duberman et al. eds., 1989); see also GARBER, supra note 23, at 67-71 (telling story of jazz musician Billy Tipton, who was discovered upon death in 1989 to have been female, to surprise of Tipton's coworkers, wife, and three adopted sons). Stories like Tipton's involving passing not only on the job so as "to improve her chances of success as a jazz musician," according to a New York Times obituary, id. at 68, but also in her personal life, raise questions as to the limits of categorization. Was Billy Tipton a woman passing as a man? A lesbian? A female-to-male transsexual? More importantly, what piece of law reform, if any, would make Billy Tipton happy-Title VII, gay marriage, birth certificate amendments to change sex? In part it is because I think different answers can be presented to these questions by different people living a life like Billy Tipton's that I think sex, gender, and orientation should be pulled further apart conceptually, rather than moved closer together. For an analysis of Billy Tipton as a lesbian, see Franke, supra note 36, at 35.

91. For discussion of a recent expansion of protection for masculine women, see Abrams, supra note 39, at 2511 n.121 (arguing that Harris v. Forklift Sys., Inc., 114 S. Ct. 367 (1993), which held that plaintiff in hostile environment sexual harassment case need not show serious psychological damage, extends protection from harassment to women who do not respond to it in stereotypically feminine ways, but rather with more stereotypically masculine toughness).

92. Christine Littleton has applied the term "phallocentrism" to the

insidious and complex form of male domination ... . by which those things culturally identified as "male" are more highly valued than those identified as "female," even when they appear to have little or nothing to do with either biological sex. By this process, "to be a man" does not simply mean to possess biologically male traits, but also to take on, or at least aspire to, the culturally male.

Littleton, supra note 63, at 1280 (footnote omitted). Littleton notes that "[b]ecause the links between biological and cultural sex are so tenuous, it is possible for individuals to engage in cultural 'cross-dressing,' thus complicating any analysis (such as legal analysis of sex discrimination) that depends on clear identification of "immutable characteristics." Id. at 1280 n.8. What she calls "cultural sex," I call "gender." 
women who most closely resemble Hic Vir. As Catharine MacKinnon puts it:

$[\mathrm{H}]$ aving to be the same as men to be treated equally remains the standard. A current example is Price Waterhouse v. Hopkins, in which Ann Hopkins was made partner . . . for meeting the male standard, a victory against holding her to a "femininity" standard. The victory lies in the recognition of women's merits when they meet the male standard. The limits lie in the failure to recognize that the standard is a male one.

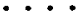

... Until this model based on sameness and difference is rejected or cabined, sex equality law may find itself increasingly unable even to advance women into male preserves-defined as they are in terms of socially male values and biographies-for the same reason it cannot get courts to value women's work in spheres to which women remain confined. Such a law can prohibit holding women to feminine standards in the workplace but not holding them to masculine ones. ${ }^{93}$

What, then, are the protections from discrimination that are or should be available to the masculine man, the masculine woman, the effeminate man, and the feminine woman $?^{94}$ The masculine man is not generally seen to need protection from discrimination; ${ }^{95}$ rather, he is usually seen as the standard by which all others are measured. ${ }^{96}$ As I shall discuss in detail below, Hopkins ensures some protection for the masculine woman, at least in jobs

93. Catharine A. MacKinnon, Reflections on Sex Equality Under Law, 100 YALE L.J. 1281, 1292 \& n.50, 1296-97 (1991) (citations omitted) (second through fourth sentences from footnote).

94. In discussing these polar types, I by no means intend to suggest that all, or even most, human beings can readily be categorized as one of them. We are all far more complicated than that, but I hope it will be useful to the discussion to focus it on these simplified types.

95. For example, the proponents of the addition of "sex" to Title VII noted in debate that absent this addition, only "white Christian women" would be left unprotected from discrimination, since white Christian men did not need protection and persons of both sexes of all other races and religions were already covered by the existing language. See Case, supra note 72 , at 126 n.33.

96. It is, of course, perfectly clear by now that Title VII and other antidiscrimination laws do cover discrimination against men on grounds of sex should it occur. Similarly, I would propose that we treat discrimination on the basis of masculinity, where it occurs, in a manner parallel to my proposed treatment of feminine gender discrimination. The sex discrimination charge recently filed by male employees of the Jenny Craig fitness chain is a rare example of a claim of discrimination against the masculine. The male employees complained of having to dress in feminine uniforms, being told to "get a sex-change operation and a push-up bra" if they wanted to succeed in the company, feeling excluded from office conversations centered on "girl talk," being negatively stereotyped as, for example, "sensitive for a guy," etc. The Jenny Craig organization has a female founder and namesake, an all-female board, more than $90 \%$ female employees, and an overwhelmingly female clientele. George Gordon, Men at Work?, DaILY Mall (London), Mar. 2, 1995, at 3. One male manager alleged that he "was pretty much told fiat-out that upper echelons at Jenny Craig did not want to promote men. They said things like they found our phone manner too assertive. But we were the biggest earners they had." Joe Battenfield, Jenny Craig Hit with Sex Harassment Complaint-By Men, BOSTON HeRALD, Nov. 30, 1994, at 1. As professor of management Judy B. Rosener said in commenting on the case, "To get ahead, you must be just like those at the top, and generally that's based on the straight, white, male model. . . . But a culture dominated by female talk, female ways of doing things is just as wrong." Jane Gross, Now Look Who's Taunting; Now Look Who's Suing, N.Y. TIMES, Feb. 26, 1995, § 4, at 1 . 
that reward men for displaying characteristics gendered masculine. As for the effeminate man in a workplace that encourages or tolerates feminine behavior in women, the logic of Hopkins dictates that he too should be protected: $\mathrm{He}$ is, in effect, Hopkins in drag. There is no basis in current Title VII doctrine for limiting to women the Hopkins holding that requiring conformity to the gendered behavior deemed appropriate for one's sex constitutes impermissible sex stereotyping. ${ }^{97}$ What of an employer that neither encourages nor tolerates behavior conventionally gendered feminine in members of either sex, who likes Ann Hopkins just the way she is and wouldn't change a thing about her, but won't promote her more feminine counterparts unless they go to assertiveness training class and wear man-tailored suits to work? If such an employer rewards masculinity equally in either sex and does not assume that women are less capable of manifesting masculine qualities, it is not engaging in sex discrimination narrowly defined, nor in the sort of sex stereotyping the case law has thus far prohibited. What the employer is doing is engaging in gender discrimination-favoring the masculine over the feminine rather than the male over the female.

Does the feminine tend to be devalued because it is associated with women or are women devalued because they manifest feminine characteristics $?^{98}$ Cross-cultural evidence suggests that the stronger line of causation runs from a disfavoring of women to a disfavoring of all that is associated with them, i.e., gendered feminine. Numerous scholars have noted the following phenomenon in a variety of contexts: Virtually all societies draw strong distinctions between things, behaviors, activities, and jobs gendered masculine and those gendered feminine. The content of what is gendered masculine or feminine varies radically from culture to culture, but what remains constant is that whatever is gendered feminine is seen as less valuable than what is gendered masculine. ${ }^{99}$ This is particularly apparent in

97. I realize that to argue, as I shall, that the holding of Hopkins unequivocally protects most men who, for example, wish to wear dresses to work, may seem at worst shocking and at best silly-after all, of all the possible sex/gender combinations, it is the effeminate man who is least in favor and most disturbing to cultural norms.

98. One might ask similar questions about the relationship between the disfavoring of homosexuality and of effeminacy in men. See, e.g., Valdes, supra note 29 , at 36-55.

99. Jeanne Schroeder has tried to demonstrate an even stronger version of this denigration of the feminine. According to Schroeder, while the qualities denominated masculine and feminine have undergone a 180-degree shift since the Middle Ages, what has remained constant is that qualities most valued by the culture are gendered masculine, while those denominated feminine are devalued. Thus, says Schroeder, in the Middle Ages, when connectedness was valued and individualism disfavored, men were viewed as appropriately connected, women as dangerously atomistic. Now that the culture has come to value individualism, men are viewed as appropriately autonomous, women as excessively connected. Jeanne L. Schroeder, Feminism Historicized: Medieval Misogynist Stereotypes in Contemporary Feminist Jurisprudence, 75 IowA L. REv. 1135, 1151-59 (1990). Although I find Schroeder's thesis provocative, I am afraid my own readings in medieval literature, ranging from attacks on and defenses of women, to sermons and conduct manuals, to works of theology and fiction, do not bear out the details of Schroeder's claim. Rather, it seems to me that the medievals attributed to women many of the same positive and negative qualities listed in modern sex-role inventories. Proving this by reference to specific medieval texts would be a frolic and detour here, but, for a good compendium of the virtues and vices commonly 
cross-cultural employment data. For example, notoriously, the job of physician in the United States commands high pay and high prestige, is predominantly held by men, and is seen to require chiefly such "masculine" qualities as analytic ability. By contrast, in the former Soviet Union, the job of physician is comparatively less prestigious and less well-paid, is held predominantly by women, and is seen to require chiefly such "feminine" qualities as nurturing ability. ${ }^{100}$ This is strong evidence in support of a central claim of this Article-that categorical gender discrimination (for example, across-the-board discrimination against all persons, male or female, who display feminine characteristics or who lack masculine ones) raises issues of central concern to the equality of the sexes and should be analyzed as sex discrimination. Not only is such discrimination likely to have a disparate impact on women, the close association of the disfavored qualities with women and of other, favored, qualities with men may well not be accidental-it may in fact be because some qualities are associated with women that they are disfavored. Thus, feminine women whose employer engages in gender discrimination against feminine qualities should be able to challenge this under Title VII's disparate impact prong. ${ }^{101}$

attributed to medieval women set forth in the context of a feminist defense of women's abilities and written circa 1400, see CHRISTINE DE PIZAN, THE BOOK OF THE CITY OF LADIES (Earl Jeffrey Richards trans., 1982). My expression of doubts about Schroeder's thesis as applied to the Middle Ages is not meant to suggest that gender is essential and eternal, but merely, at most, to suggest that we remain the heirs of the medievals. Nor is it to suggest that Schroeder's line of analysis will not prove fruitful when applied to other potential cross-cultural or cross-temporal comparisons. See infra text accompanying note 100.

100. As sociologists have long recognized, ... sex-typed traits commonly associated with a job often have little inherent connection with performance; instead, the perception that a job requires masculine traits typically derives from associating the job with its incumbents. For example, physicians in this country have traditionally been male, and good doctors have long been thought to exhibit traits associated with men, including detachment and rationality. In the Soviet Union, however, where seventy-five percent of physicians are women, medicine has long been considered an occupation requiring such qualities as nurturing and caring. Similarly, before the Civil War, the position of primary schoolteacher was seen as an intellectually grueling "male" occupation for which women lacked the requisite mental stamina. When the shortage of men during the Civil War necessitated the recruitment of female teachers, however, women moved into the profession, and schoolteaching was soon considered a nurturing activity which demanded a mothering presence.

Maxine N. Eichner, Note, Getting Women Work That Isn't Women's Work: Challenging Gender Biases in the Workplace Under Title VII, 97 YALE L.J. 1397, 1402 (1988) (citing CYNTHIA FUCHS EPSTEIN, WOMEN'S PlaCE: OptIONS AND LIMITS IN PROFESSIONAL CAREERS 155, 157 (1970)).

The observation that a high percentage of women is highly correlated with low prestige and low pay may contribute to male resistance to the integration of male jobs and the comparative willingness of women to promote desegregation in pink-collar ghettos. See, e.g., Mississippi Univ. for Women v. Hogan, 458 U.S. 718,729 n.15 (1982) ("Officials of the American Nurses Association have suggested that excluding men from the field has depressed nurses' wages. . . . To the extent the exclusion of men has that effect, MUW's admissions policy actually penalizes the very class the State purports to benefit."). For further exploration of the notion that virtually any job can be described as requiring either masculine or feminine qualities, see infra note 320 .

101. Additionally, men discriminated against by such an employer for displaying feminine characteristics should be permitted to raise ius tertii claims. For a summary, see supra Table 1, which sets out my view of how the various combinations of sex and gender of employees and the gendered characteristics demanded by employers play out under Title VII. 
Before going on to discuss in more detail the way all of this is and should be dealt with in the case law of sex discrimination, I think it may be useful to look more closely at the psychological and historical evidence for possible explanations for discrimination against the feminine. Historically, in life and in law, being male and being human have been defined as synonymous, such that virtue was both the virtue of males and of human beings. What does this mean in a world in which women are now seen as human? If man is indeed the universal, ${ }^{102}$ nothing is left over for masculinity when women become human. ${ }^{103}$ Today women are seen as able to do all that men do and then some, whether the additional ability is pregnancy, ${ }^{104}$ intimacy, or wearing a dress. There remains a residual femininity inaccessible to males, while masculinity is reduced to defining itself only by what it is not: ${ }^{105}$ it is not feminine. Even psychoanalysts have moved from talk of penis envy to assertions such as Nancy Chodorow's that it is easy to be a female, fragile and difficult to be a male. ${ }^{106}$ This was not

102. This is the claim of those who insist "man" and masculine pronouns include women.

103. This is obvious in much of the men's movement literature that defines goals and ideal behavior for men. Consider, for example, the Rites of Passage promulgated by Ronald F. Johnson, Jawanza Kunjufa et al., designed "to prepare boys to be men," and adopted by the organizers of the ill-fated Detroit Male Academy. See DETROIT BD. OF EDUC., MALE ACADEMY GRADES K-8: A DEMONSTRATION PROGRAM FOR AT-RISK MALES 33-35 (1991) (setting forth personal, spiritual, economic, emotional, physical, etc. rites of passage for males); see also Garrett v. Board of Educ., 775 F. Supp. 1004, 1007 (E.D. Mich. 1991) (invalidating as discriminatory on basis of sex plan to create public primary school exclusively for African-American males). One can substitute the word "woman" for the word "man" everywhere the latter appears in the Rites of Passage program and read the result without a single double take. Cf. NOW v. Little League Baseball, Inc., 318 A.2d 33, 39 (N.J. 1974) (rejecting claim by baseball organization that admission of girls would impair its objective of development in children of "qualities of citizenship, sportsmanship, and manhood" because "assuming 'manhood,' in the sense of the charter, means basically maturity of character, just as does 'womanhood,' we fail to discern how and why little girls are not as appropriate prospects ... as are boys"). But see Catherine S. Manegold, "Save the Males" Becomes Battle Cry in Citadel's Defense Against Woman, N.Y. TIMES, May 23, 1994, at A10 ("We know how to train young men how to be men. We don't know how to train young women how to be men. We don't even know how to train young women how to be women.") (quoting Major Rick Mill, a Citadel alumnus and spokesman).

104. Much feminist jurisprudential writing on the subject of pregnancy discrimination has sought to recapture the notion that pregnancy is an ability women have that men lack, rather than a disability, analogizable to such ailments as the flu or prostate trouble. See Littleton, supra note 63, at 1306.

105. Those who would dispute this claim include, for example, the new proponents of gendered parenting roles, who insist that "fathering" is not just the manifestation in males of generic "parenting" skills, but necessarily and beneficially applies masculine discipline as a counterpoise to feminine nurturing. See Johnette Howard, For McCartney, a Leap of Faith, WASH. PosT, Oct. 25, 1994, at E1 (describing Tony Evans's Seven Promises of a Promise Keeper, Christian men's movement book "trac[ing] the decline of the American family or the "feminization of men'" and offering advice on "family crises" such as one's "college son return[ing] home with an earring").

106. According to Chodorow, as a result of women's predominant role in parenting,

Masculinity becomes an issue in a way femininity does not. . . Dependence on his mother, attachment to her, and identification with her represent that which is not masculine.... Masculine gender role training becomes more rigid than feminine. A boy represses those qualities he takes to be feminine inside himself, and rejects and devalues women and whatever he considers to be feminine in the social world. terms.

Thus, boys define and attempt to construct their sense of masculinity largely in negative

NANCY J. Chodorow, The Reproduction of Mothering: Psychoanalysis and the Sociology of GENDER 181-82 (1978). Note that while I am, for the sake of convenience, using Chodorow as my chief 
always the case-females, not males, were conventionally defined as "lack": Aristotle called them defective males; ${ }^{107}$ Freud stressed that they were missing a penis; ${ }^{108}$ Lacanians identified the feminine as negativity. ${ }^{109}$ But today the need for males to police gender boundaries against any intrusion of the feminine is doubly important. ${ }^{110}$ It was always seen as necessary to guard against taint by the inferior. ${ }^{111}$ Now, in addition, it may be the only way to define masculinity at all, there being little or nothing left exclusive to men in this culture.

\section{THE CASE LaW OF GeNDER BENDING}

\section{A. Herein of Ann Hopkins and Bennie Smith}

\section{Hopkins and Sex Stereotyping}

In Price Waterhouse v. Hopkins, ${ }^{112}$ the case that forms the centerpiece of my discussion of gender discrimination, neither the Justices nor the parties seem to have seen the Court as breaking new ground on the questions of sex stereotyping central to this Article. ${ }^{113}$ Rather, the Court's approach was that

source for this line of argument, it is far from unique to her; nor is acceptance of this point tied to any acceptance of the rest of Chodorow's theories or prescriptions. For a summary of Chodorow's views on masculinity and femininity, see RHODA UNGER \& MARY CRAWFORD, WOMEN AND GENDER: A FEMINIST PSYCHOLOGY 34-35 (1992). Chodorow's solution is a gender-blending one-she wants men to participate more in their children's care and socialization. NANCY J. CHODOROW, FEMINISM AND PSYCHOANALYTIC THEORY 44 (1989).

107. See ARISTOtle, Generation of ANmals 103 (A.L. Peck trans., Harv. Univ. Press 1943).

108. See SIGMUND FREUD, NEW INTRODUCTORY LECTURES ON PSYCHOANALYSIS 126-27 (James Strachey ed. \& trans., 1965). But cf. BEM, supra note 32, at 149. Bem recounts that, when her son Jeremy decided to wear barrettes to nursery school[,] . . . another little boy insisted that Jeremy must be a girl because "only girls wear barrettes." After repeatedly insisting that "wearing barrettes doesn't matter, being a boy means having a penis and testicles," Jeremy finally pulled down his pants to make his point more convincingly. The other boy was not impressed. He simply said, "Everybody has a penis; only girls wear barrettes."

Id.

109. See, e.g., Drucilla Cornell \& Adam Thurschwell, Feminism, Negativity, Intersubjectivity, in FEMINISM AS CRITIQUE 143, 148 (Seyla Benhabib \& Drucilla Cornell eds., 1987).

110. The perceived need for such policing is perhaps best summed up by the schoolyard concept of "cooties"-the belief that certain forms of contact with the feminine can contaminate males. For a theoretical framework for cultural understandings of this and other forms of ritual impurity, see generally MARY DOUGLAS, PURTTY AND DANGER: AN ANALYSIS OF CONCEPTS OF POllutION AND TABOo (1966).

111. As Joan Williams summarizes research on early modern employment patterns:

[W]hile women could perform male activities so long as they were acting under the supervision and authority of their husbands, men did not similarly cross over and perform women's activities. This is the classic pattern, today best illustrated by patterns of dress: it is easier to persuade the dominant group to share its privileges with the subservient group than it is to persuade the dominant group to threaten its status by adopting behaviors associated with subservience. In short, real women may wear tuxedos, but real men do not wear high heels.

Joan C. Williams, Deconstructing Gender, 87 MICH. L. REV. 797, 823 n.10S (1989) (citing LAUREL THATCHER ULRICH, GOOD WIVES 14-50 (1980)).

112. 490 U.S. 228 (1989).

113. Although the plurality opinion noted that "the parties do not overtly dispute" the proposition that either presuming or requiring conformity of gender to sex is sex discrimination prohibited by Title VII, it 
it had set its face against sex stereotyping throughout its modern constitutional and statutory sex discrimination jurisprudence. ${ }^{114}$ It is true that the Court had indeed condemned what it called sex stereotyping since the early 1970s, when Ruth Bader Ginsburg appeared before it to challenge statutes that on their face discriminated against women. ${ }^{115}$ And EEOC regulations implementing Title VII had also consistently prohibited reliance on "stereotyped characterizations of the sexes." Moreover, the Court had early on insisted that "[i]n forbidding employers to discriminate against individuals because of their sex, Congress intended to strike at the entire spectrum of disparate treatment of men and women resulting from sex stereotypes."117

But the sex stereotyping at issue in those cases and in the examples provided in the EEOC regulations bore only a family resemblance to that which affected Ann Hopkins's chances for promotion. Without explicitly acknowledging the fact, the Court, as it was faced with increasingly subtle and complex barriers to the equality of the sexes, has gradually broadened its conception of impermissible sex stereotyping, lumping together under the same general heading several related but conceptually distinguishable phenomena. Hopkins, in my view, marked the third generation of sexstereotyping cases in the courts. Briefiy stated, the first generation focused on the assumption that an entire sex conformed to gender stereotypes; the second on the assumption that individual members of the sex did; the third on individuals penalized because their gender behavior did not conform to stereotypical expectations. Fourth-generation stereotyping claims, of the sort I endorse in this Article, might take on the stereotyping of the job and its requirements rather than of the person holding or applying for it, challenging

took Price Waterhouse to task for putting "sex stereotyping" in quotation marks throughout its briefs, and thereby, in the Justices" view, "insinuati[ng] either that such stereotyping was not present in this case or that it lacks legal relevance." Id. at 250 . Not only did the Court, in reviewing the sufficiency of the evidence, find stereotyping to be present as a matter of fact in Hopkins's case, but it also insisted that "[a]s for the legal relevance of sex stereotyping, we are beyond the day when an employer could evaluate employees by assuming or insisting that they matched the stereotype associated with their group." Id. at 251.

114. The issue before the Court was seen to be not the law with respect to stereotyping, but the appropriate allocation of the burden of proof as to the part sex played in an employment decision. Price Waterhouse did dispute before the Court "both that stereotyping occurred and that it played any part in the decision" against Hopkins, but this was not a challenge to the legal definition of stereotyping, only to the district court's factual conclusions, which the Supreme Court held were not clearly erroneous. Id. at 255.

115. Frontiero v. Richardson, 411 U.S. 677, 685 (1973).

116. EEOC Guidelines on Discrimination Because of Sex, 29 C.F.R. \$ 1604.2 (1994). Indeed, although the Supreme Court went on to apply stereotyping analysis in constitutional as well as statutory cases, it may well have gotten the concept of sex stereotyping from the EEOC and lower court Title VII decisions. The earliest Supreme Court reference I could find is in Justice Marshall's 1971 concurrence in Phillips v. Martin Marietta Corp., 400 U.S. 542, 545 (1971) (Marshall, J., concurring), a Title VII case. The term appears to enter the Court's constitutional vocabulary in Frontiero, three years later. It had been in use in EEOC guidelines, EEOC cases, and lower court Title VII cases since the 1960s.

117. Los Angeles Dep't of Water \& Power v. Manhart, 435 U.S. 702, 707 n.13 (1978) (quoting Sprogis v. United Air Lines, 444 F.2d 1194, 1198 (7th Cir. 1971)). 
the assumption that qualities gendered masculine (or, more rarely, feminine) are essential to success rather than demanded merely by stereotypical expectations. ${ }^{118}$

First-generation sex stereotyping was legislative or quasi-legislative. ${ }^{119}$ It took its cue from Justice Bradley's claim in Bradwell, ${ }^{120}$ that the laws are not made for exceptional cases, and took the form of a blanket ban, a categorical exclusion of all members of one sex based on assumptions (whether accurate or not was beside the point) ${ }^{121}$ about the abilities, qualifications, or inclinations of most of them. ${ }^{122}$ Both the EEOC and the

118. These are the sort of claims I envision being brought under the disparate impact approach to gender discrimination I discuss below.

119. Several of the early EEOC cases, for example, involved state law or industry-wide prohibitions on women's employment in jobs requiring the lifting of heavy weights. Since at least 1968, EEOC interpretations of its guidelines on a BFOQ for sex had called into question state laws and regulations limiting the employment of women on the basis of stereotypical assumptions about their capacities, such as laws limiting the maximum weight that women employees would be permitted to lift. See, e.g., Bowe v. Colgate-Palmolive Co., 416 F.2d 711, 717 (7th Cir. 1969) (describing EEOC view that general weight limits by sex are "violative of its prohibition against the use of broad class stereotypes including those in which sex is the stereotyping factor" as well as "arbitrary and discriminatory and based on a "stereotyped characterization of the sexes,' rather than consideration of individual capacities as to physical strength and particular job requirements"). Both the EEOC and the Supreme Court have insisted that the BFOQ for sex should be interpreted narrowly. See UAW v. Johnson Controls, Inc., 499 U.S. 187, 201 (1991); 29 C.F.R. $\S 1604.2$ (a) (1972).

120. See Bradwell v. Illinois, 83 U.S. 130, 141-42 (1872) (Bradley, J., concurring). This infamous case upheld a prohibition against the admission of women to the practice of law. Justice Bradley, concurring, justified the ban by reference to women's natural duty to their husbands, children, and households. He acknowledged that:

It is true that many women are unmarried and not affected by any of the duties, complications, and incapacities arising out of the married state, but these are exceptions to the general rule. . . .

And the rules of civil society must be adapted to the general constitution of things, and cannot be based upon exceptional cases.

Id. In Frontiero v. Richardson, the case Ruth Bader Ginsburg argued in which the Court for the first time explicitly adopted a sex-stereotyping approach to constitutional law, the Court quoted Bradley on women's domestic role only to conclude that, "[a]s a result of notions such as these, our statute books gradually became laden with gross, stereotyped distinctions between the sexes and, indeed, throughout much of the nineteenth century the position of women in our society was, in many respects, comparable to that of blacks under the pre-Civil War slave codes." 411 U.S. at 685 . The stereotype at issue in Frontiero-that men were breadwinners and women their dependents-was one the Court did not allow to be embodied in a law that distinguished on its face between married male and female armed services personnel in the distribution of benefits. As with its opposition to sex stereotyping in Title VII cases, so in Frontiero, the Court opposed "invidiously relegating the entire class of females to inferior legal status without regard to the actual capabilities of its individual members." Id. at 687 . Whether the classification was meant to benefit women or exclude them was not the issue. As the Court was later to hold in yet another Ginsburg case, which involved the award of alimony to wives only:

Legislative classifications which distribute benefits and burdens on the basis of gender carry the inherent risk of reinforcing stereotypes about the "proper place" of women and their need for special protection. ... Where . . . the State's compensatory and ameliorative purposes are as well served by a gender-neutral classification as one that gender classifies and therefore carries with it the baggage of sexual stereotypes, the State cannot be permitted to classify on the basis of sex.

Orr v. Orr, 440 U.S. 268,283 (1979).

121. But see Manhart, 435 U.S. at 708 (noting that "[e]ven a true generalization about the class is an insufficient reason for disqualifying an individual to whom the generalization does not apply").

122. Thus, a typical rule derived from such a stereotype would say, in effect, "because most women do not or cannot, no woman shall." Note that most such regulations might well have passed the rational basis test of constitutional equal protection law-most women probably cannot lift hundred-pound weights; 
courts quickly made clear that this sort of stereotyping constituted illegal sex discrimination. According to EEOC Guidelines, ${ }^{123}$ for example:

[T] he following situations do not warrant the application of the bona fide occupational qualification exception. . . . (ii) The refusal to hire an individual based on stereotyped characteristics of the sexes. Such stereotypes include, for example, that men are less capable of assembling intricate equipment; that women are less capable of aggressive salesmanship. The principle of non-discrimination requires that individuals be considered on the basis of individual capacities and not on the basis of any characteristics generally attributed to the group. ${ }^{124}$

Second-generation sex stereotyping cases involved not general rules, but application to particular individuals. Even in the absence of any blanket ban on hiring women or any assertion that sex was a BFOQ for the job in question, some employers tended to assume that a particular applicant embodied the stereotypes associated with her or his sex. Such cases point up the potentially distorting effects of what Bem has called the lenses of gender ${ }^{125}$ - the polarizing lenses of gender can filter out certain parts of the gendered spectrum, intensifying one's ability to see the others. In addition, the lenses of gender may either magnify or minify gendered characteristics. What I mean by this is that, in describing a person in terms of conventionally gendered characteristics, it is difficult to know how accurate one's perceptions are, how much they may be influenced, and in which direction, by one's gendered expectations. Does one tend to focus on a woman's feminine characteristics because one expects to find them in her? Or does one concentrate instead on the ways she may diverge from feminine expectations, accentuating any masculine characteristics one may perceive? In looking at

on the flip side, most men may not have the soothing personality required of flight attendants. See Diaz v. Pan Am. World Airways, 442 F.2d 385 (5th Cir. 1971). As a matter of administrative convenience, it may be easier and cheaper not to search for the one in a thousand who can pass the test. Where protected classes are at issue, however, both constitutional and statutory antidiscrimination law require that the exceptional person be given a chance.

123. As early as 1970, in his concurring opinion in Phillips v. Martin Marietta Corp., 400 U.S. 542 (1970), which concerned an employer's refusal to hire women, but not men, with school-age children, Justice Marshall relied on these guidelines in denying that Title VII "permits ancient canards about the proper role of women to be a basis for discrimination." Id. at 545 (Marshall, J., concurring).

124. EEOC Guidelines on Discrimination Because of Sex, 29 C.F.R. $\S 1604.2$ (1995). Note that nothing in the EEOC's formulation addresses stereotyping of the job, rather than of the applicant. Thus, while it constitutes sex discrimination to assume that "women are less capable of aggressive salesmanship," there is no suggestion in the regulations that there is any problem with the assumption that successful salesmanship requires aggressiveness, a trait gendered masculine. The regulations merely give individual women the opportunity to prove that they can be as aggressive (as masculine?) as is assumed to be required.

125. BEM, supra note 32 . I take only the phrase from Bem, not the details of her analysis, although I believe my use of the phrase is not inconsistent with hers. 
a man, is one more likely to see mild-mannered Clark Kent or Superman $?^{126}$

The second-generation stereotyping cases were those in which the lenses of gender worn by those making employment decisions magnified those gender characteristics seen as appropriate to the employee's sex and filtered out those that were not, even if they were present in the employee and required for the job. Thus, for example, even though the city of El Segundo, California did not categorically refuse to hire women as police officers, the Ninth Circuit held that it refused to hire a particular woman, Deborah Lynne Thorne, because of its "stereotyped view of the physical abilities of women" and because those responsible for reviewing her application applied a different "standard of moral integrity" to her application than was applied to similarly situated males. ${ }^{127}$ The district court had found that the decision not to hire Thorne was based on "subjective factors applied in good faith such as aggressiveness, self-assurance, motivation, candor and high moral standards." 128 The Ninth Circuit reversed, not because it saw anything wrong with requiring such masculine qualities as "aggressiveness" from a police officer, but because the evidence indicated that it was only the hiring officers' stereotyped views of women, not anything they observed in Thorne herself, that led them to find her wanting-looking at her through the lenses of gender, they saw only what they were expecting to see. ${ }^{129}$

126. This does not depend entirely on the "costume" the man may be wearing, as another movie analogy may help illustrate. In the movie Annie Hall, the Woody Allen character, a secular New York Jew, visits the Middle American home of his WASP girlfriend Annie Hall for Thanksgiving dinner. The movie first shows all of the people gathered around the table, looking like fairly unremarkable, average Americans. Then it shows us how they look to each other: To the WASPs, the balding, clean-shaven, tweed-jacketed Woody Allen looks like a Hasid, with seventeenth-century style black hat and coat, long beard, and earlocks; this is what they expect to see when they look at what Grammy Hall calls "a real Jew." To Allen, the family looks like American Gothic. The lenses of gender can have a similar effect.

127. Thorne v. City of El Segundo, 726 F.2d 459, 464 (9th Cir. 1983). Thorne, who had received the second highest score of all the applicants on the combined oral and written tests, id. at 462 , had been passed over in favor of the male who placed third, $i d$. at 463 . The double moral standard was applied when she was faulted for becoming pregnant as a result of an affair with a married police officer, although he was not reprimanded. Id. at $466-67$.

128. Id. at 464 .

129. The Ninth Circuit offered a hiring officer's testimony to demonstrate that his opinion regarding Thorne's physical ability was exclusively based on preconceived ideas about women:

Q: . . . Now you also indicate ... that, quote, she is a very feminine type person who is apparently very weak in her upper body, unquote. Now were you basing that on your intuitive feeling?

A: ... [T] hat was an observation I made over those [four] years [I have known her].

$\mathrm{Q}$ : What in those four years ... did she do or not do that caused you to believe that she was apparently very weak in her upper body?

A: Just from her physical appearance.

$\mathrm{Q}$ : Is there ever any occasion where she was not able to lift something or do something

in the department because of lack of strength?

A: Not that I am aware of.

Q: What did you mean when you said that she was a very feminine type person?

A: Girlish, feminine as opposed to masculine.

....

Feminine in regard to not being as strong as a male .... 
The sex stereotyping that caused Ann Hopkins's failure to be promoted-third-generation sex stereotyping-was of a very different sort from that inflicted on Thorne. Of the two principal ways to superimpose the conventional gender schema on a person of a particular sex-one which forces a fit and the other which exaggerates the lack of fit-Thorne was found to suffer from the former, Hopkins from the latter. Thorne was faulted for being too feminine, Hopkins for not being feminine enough; Thorne was perceived to conform too well to stereotypes, Hopkins to deviate too far from them; while the stereotyping of Thorne was descriptive, that applied to Hopkins was prescriptive-it centered on how she ought to behave.

Ann Hopkins was the only woman among eighty-eight persons considered for partnership at the accounting firm of Price Waterhouse in 1982. She had at that point worked at the firm for five years, and she had "generated more business for Price Waterhouse" and "billed more hours than any of the other candidates under consideration" that year. ${ }^{130}$ Partnership decisions were made on the basis of a recommendation by the firm's Admissions Committee to its Policy Board either "to submit the candidate's name to the entire partnership for a vote, to 'hold' her candidacy [until the following year], or to reject her."131 The Policy Board, which recommended that Hopkins's candidacy be placed on hold, considered written comments supplied by members of the partnership, not all by partners who had worked closely with the candidate. ${ }^{132}$ Both her supporters and her detractors in the partnership, as well as her clients, described Hopkins as manifesting stereotypically masculine qualities, for better and for worse. She was praised for, among other things, a "strong character, independence and integrity,"” "decisiveness, Id. at $465-66$.

Q: Do you feel that women generally are strong enough to be police officers?

A: Generally speaking, no.

Similar testimony was elicited with respect to another hiring officer's assumptions about Thome's failure to "display sufficient aggressiveness, self-assuredness or probable physical ability to presently handle herself in stress situations." Id. at 467.

For a post-Hopkins example of this sort of stereotyping, see Lindahl v. Air France, 930 F.2d 1434, 1439 (9th Cir. 1991) (finding comments that male candidate was "aggressive and cool," and able to "take hold immediately of the situation," and female candidate "nervous and emotional" suggested that hiring decision was made "on the basis of stereotypical images of men and women, specifically that women do not make good leaders because they are too "emotional"').

130. Hopkins v. Price Waterhouse, 825 F.2d 458, 462 (D.C. Cir. 1987). Particularly noteworthy was the key role she played in obtaining a major contract with the Department of State, a role the partners in her office described as an "outstanding performance." Id. The fact that Hopkins excelled on all objective measures of performance strengthened the case that subjective objections to her candidacy were impermissibly tainted by sex stereotyping. See id. at 466 .

131. Price Waterhouse v. Hopkins, 490 U.S. 228, 232 (1989).

132. Id at 232-33. Price Waterhouse had no fixed limits on the number of persons it would promote to partnership, nor any fixed criteria for promotion. Of the 88 eligible persons, 47 were admitted, 21 were rejected outright, and 20 were placed on hold. $I d$. at 233 . Before the time for reconsideration came, Hopkins lost the support of two partners in her office and was told she would not be reconsidered. There was no dispute that this amounted to a constructive discharge. Id. at 233 n.1. 
broadmindedness, and 'intellectual clarity," and for being "extremely competent, intelligent," "sstrong and forthright, very productive, energetic and creative," "“a stimulating conversationalist," and "'a highly competent project leader who ... pushed vigorously to meet deadlines and demanded much from"" her staff. ${ }^{133}$

On too many occasions, however, Hopkins' aggressiveness apparently spilled over into abrasiveness. ... Virtually all of the partners' negative remarks about Hopkins-even those of partners supporting her-had to do with her "interpersonal skills." Both "[s]upporters and opponents of her candidacy," stressed [District] Judge Gesell, "indicated that she was sometimes overly aggressive, unduly harsh, difficult to work with and impatient with staff."

There were clear signs ... that some of the partners reacted negatively to Hopkins' personality because she was a woman. One partner described her as "macho"; another suggested that she "overcompensated for being a woman"; a third advised her to take "a course at charm school." Several partners criticized her use of profanity; in response, one partner suggested that those partners objected to her swearing only "because it's a lady using foul language." Another supporter explained that Hopkins "ha[d] matured from a tough-talking somewhat masculine hard-nosed [manager] to an authoritative, formidable, but much more appealing lady [partner] candidate." But it was the man who ... bore responsibility for explaining to Hopkins the reasons for the Policy Board's decision to place her candidacy on hold who delivered the coup de grace: in order to improve her chances for partnership, [he] advised, Hopkins should "walk more femininely, talk more femininely, dress more femininely, wear make-up, have her hair styled, and wear jewelry." "134

The evidence indicated that interpersonal skills were required of both male and female candidates, and that men as well had been faulted for abrasiveness, although none seems to have been told that a change of wardrobe would help. What the evidence did not (and given the distorting effect of the lenses of gender on us all probably could not) indicate is what Ann Hopkins actually looked or acted like. ${ }^{135}$ To what extent did the partners fault her for behavior they would have found equally offensive in a man and to what extent were they influenced by the fact that it was " a lady

133. Id. at 234.

134. Id. at 234-35 (citations omitted) (second and third alterations in original).

135. Was she Woody Allen or a Hasid? See supra note 126. 
using foul language"'? ${ }^{136}$ Readers of the opinion will never know how aggressive or how masculine in appearance ${ }^{137}$ Ann Hopkins really was. ${ }^{138}$

Hopkins bolstered her case with the expert testimony of psychologist Susan Fiske, an authority in the field of sex stereotyping who analyzed the partners' written comments for evidence of such stereotyping. Price Waterhouse, which had raised no objections to Fiske's expertise in the district court, claimed on appeal that because Fiske "had never met Hopkins and had no idea what her conduct or behavior was like,"139 Fiske was in no position to know whether the criticisms resulted from stereotyping or were simply unbiased observations. ${ }^{140}$ The dissenters on the Supreme Court found this objection plausible. According to them,

Fiske purported to discern stereotyping in comments that were gender neutral-e.g., "overbearing and abrasive" — without any knowledge of the comments' basis in reality and without having met the speaker or subject. "To an expert of Dr. Fiske's qualifications, it seems plain that no woman could be overbearing, arrogant, or abrasive: any observation to that effect would necessarily be discounted as the product of stereotyping. If analysis like this is to prevail in the federal courts, no employer can base any adverse action as to a woman on such attributes."141

The concern of the Hopkins dissenters that courts would be unable or

136. Hopkins, 490 U.S. at 235; see also Martha Chamallas, Listening to Dr. Fiske: The Easy Case of Price Waterhouse v. Hopkins, 15 VT. L. REV. 89, 105 (1990) (noting difficulty in determining basis of partners' assessment of Hopkins). The same analysis can be applied to O.J. Simpson prosecutor Marcia Clark, who was told she came across as a "bitch." Do those looking at Marcia Clark see a bitch merely because any woman in that role would be perceived as a bitch? Do they see a bitch because even on a scale of assertive women she is very assertive? Or because even on a scale of assertive human beings she is off the chart? Perhaps because juries are harder to sue for sex discrimination than accounting firms, Clark has in fact taken the advice given Hopkins to "dress more femininely," "have her hair styled," and go to "charm school." See, e.g., Ellen Goodman, Styles in Conflict, BosTon GloBE, Oct. 20, 1994, at 19 (deseribing makeover of Clark's appearance and behavior to create warmer, softer, more feminine, and less abrasive impression on jury and media).

137. Because the record before the Supreme Court is devoid of any evidence as to what Ann Hopkins actually looked like, it is difficult to see how disparate grooming standards for the two sexes can survive Hopkins. See infra Subsection IV.B.2.

138. As Hopkins herself put it, "To be difficult to work with is somewhat in the eye of the beholder." Richard Lacayo, A Hard Nose and a Short Skirt: Two Cases Raise Hard Questions About a Woman's On-the-Job Style, TiME, Nov. 14, 1988, at 98 (quoting Hopkins).

139. Hopkins, 825 F.2d at 467.

140. Id. For an analysis of the gendering of Dr. Fiske and her field of expertise, see Chamallas, supra note 136, at 120-21 (highlighting dissenting judge's emphasis on Fiske's womanly "intuitions"). Compare the reference to intuitive feeling, a supposedly feminine quality, in the cross-examination of the hiring officer in Thorne, 726 F.2d at 465-66 (noting male hiring officer's "intuitive feeling" that plaintiff lacked necessary physical strength).

141. Hopkins, 490 U.S. at 293 n.5 (Kennedy, J., dissenting) (quoting Hopkins, 825 F.2d at 477 (Williams, J., dissenting)). Of course, to say the comments are gender neutral is to beg the question. Are the Price Waterhouse partners like the BSRI, which makes no distinction between a man and a woman displaying gendered characteristics? Or did they perceive the same behavior differently depending upon the sex of the person manifesting it? 
unwilling to distinguish sexist allegations of personality flaws from criticism of behavior that would negatively affect the performance of persons of either sex seems not to have materialized. Instead, courts have rejected the claims of most assertive women who have raised Hopkins-like claims, finding that the plaintiffs really were too abrasive and, thus, that criticisms of them were legitimate rather than the result of stereotyping. ${ }^{142}$ Of course, the same distorting effect of the lenses of gender may be at work in these cases-just as with Ann Hopkins, we can never know what these women were really like and what part gendered expectations played in how they were perceived by their employers or by the courts. ${ }^{143}$ For the Hopkins plurality, ${ }^{144}$ however, expert testimony seemed unnecessary to her case:

\section{It takes no special training to discern sex stereotyping in a description of an aggressive female employee as requiring "a course at charm}

142. For a post-Hopkins case, see Mann v. Montgomery, No. 84-C11020, 1994 U.S. Dist. LEXIS 9893, at *6-7 (N.D. Ill. July 18, 1994) (granting partial summary judgment for defendant because, although defendant considered comments that plaintiff was "too pushy or aggressive and lacked humility" in determining to terminate her, "[t]here was nothing wrong in defendant's . . . considering plaintiff's having poor interpersonal skills and there was no evidence that he would have considered the same traits as positive or even neutral in a male employee"). For pre-Hopkins cases in which female plaintiffs lost on the facts, rather than because the court rejected sex-stereotyping claims on principle, see, e.g., McCarthney v. Griffin-Spalding County Bd. of Educ., 791 F.2d 1549, 1551-53 (11th Cir. 1986); Ullman v. Olwine, Connelly, Chase, O'Donnell \& Weyher, 123 F.R.D. 237, 245-47 (S.D. Ohio 1987); Fogg v. New England Tel. \& Tel. Co., 346 F. Supp. 645, 649-51 (D.N.H. 1972). In Fogg, the plaintiff exhibited qualities gendered masculine such as aggressiveness, whereas, unusually, the court found that qualities gendered feminine such as deference were required at her job level. Compare this with social science research, see infra note 247 , that suggests that the more subservient the position the more likely it is that feminine and not masculine qualities will be seen as desirable. Mary C. Dunlap interpreted Fogg as part of a pattern of cases reflecting the

vulnerability of nonconformists to losses of employment and other opportunities due to hair length, dress style, "effeminate" manners by men, "masculine" manners by women, improper choices of sexual partners, statements of personal belief in freedom as to sexual identity, sex reassignment surgery and transsexualism, and various other statements and conduct perceived to be outside the bounds of the person's legally prescribed sexual identity.

Mary C. Dunlap, The Constitutional Rights of Sexual Minorities: A Crisis of the Male/Female Dichotomy, 30 HASTINGS L.J. 1131, 1135-36 (1979) (footnote omitted); see Rabidue v. Osceola Refining Co., 805 F.2d 611,615 (6th Cir. 1986) (rejecting sexual harassment claim of woman who displayed both positive and negative stereotypically masculine traits and was fired for manifesting negative ones, notwithstanding that, according to one judge, supervisor who harassed plaintiff displayed same traits and received "fatherly advice and ... praise for potential"); see also id. at 624 (Keith, J., concurring and dissenting).

143. For a successful post-Hopkins claim, see Adair v. Beech Aircraft Corp., 782 F. Supp. 558, 562-64 (D. Kan. 1992) (finding plaintiff entitled to promotion and back pay under Title VII). For a successful pre-Hopkins claim, see Shaw v. Nebraska Dep't of Correctional Servs., 666 F. Supp. 1330, 1334-39 (D. Neb. 1987), in which the plaintiff benefitted both from strong testimony of explicitly discriminatory statements and by the ability of at least some of her coworkers to value her personality. As members of management learn from Hopkins, if nothing else, to avoid explicitly sexist statements (although perhaps not to root out stereotyping), future plaintiffs may have a more difficult time proving their cases.

144. The disagreement of those concurring was not on the sex stereotyping theory of liability nor on the sufficiency of the evidence, but only on the burden of proof. It is somewhat unclear what position the dissent takes on Hopkins's theory of sex stereotyping, as distinguished from the burden of proof and sufficiency of the evidence. It does say that "[a]ttempts to evade tough decisions by erecting novel theories of liability or multitiered systems of shifting burdens are misguided," Hopkins, 490 U.S. at 295 (Kennedy, J., dissenting), but it also finds that "Hopkins plainly presented a strong case . . . of the presence of discrimination in Price Waterhouse's partnership process," id. 
school." Nor . . . does it require expertise in psychology to know that, if an employee's flawed "interpersonal skills" can be corrected by a soft-hued suit or a new shade of lipstick, perhaps it is the employee's sex and not her interpersonal skills that has drawn the criticism. ${ }^{145}$

The Hopkins plurality seems, however, to have placed a great deal of weight on the doubleness of Hopkins's bind: "An employer who objects to aggressiveness in women but whose positions require this trait places women in an intolerable and impermissible Catch-22: out of a job if they behave aggressively and out of a job if they do not. Title VII lifts women out of this bind."146 This raises the intriguing question of what would have happened had the double bind been dissolved. As it was, the case was made relatively easy by the near impossibility of Hopkins's meeting both job performance and gender role expectations. The Supreme Court saw the fine line professional women must tread-aggressive enough to get the job done but not too aggressive to frighten anyone-reduced in Hopkins's case almost to a vanishing point. She simply could not do both. But the Court seemed to find the masculine part of the bind unproblematic. It gave no indication that it was anything other than perfectly acceptable for her employer to expect Hopkins to be tough, aggressive, and stereotypically masculine to do the job. What was impermissible was simultaneously to ask her to do the nearly impossible ${ }^{147}$ by also being a perfectly gendered feminine female.

As for the feminine part of the bind, it seems clear that, even standing alone, it would support a finding of liability under Title VII. If the double bind had been dissolved in favor of gender conformity-if Hopkins's success had not depended on her display of masculine characteristics, ${ }^{148}$ but Price Waterhouse had still required her to behave more femininely simply because this was expected in a woman-the firm would still have been treating Hopkins differently from a similarly situated man, taking her sex into account in violation of Title VII. ${ }^{149}$

145. Id. at 256.

146. Id. at 251 .

147. Perhaps only quite difficult, not literally impossible, given that the district court found that other women "[c]andidates were viewed favorably if partners believed they maintained their femin[in]ity while becoming effective professional managers." Hopkins v. Price Waterhouse, 618 F. Supp. 1109, 1117 (D.D.C. 1985), modified, 825 F.2d 458 (D.C. Cir. 1987), rev'd, 490 U.S. 228 (1989).

148. For example, if Hopkins had been in a job that was not itself thought to require the display of masculine or feminine characteristics-if, for example, like Bennie Smith of Smith v. Liberty Mutual Insurance Co., 569 F.2d 325 (5th Cir. 1978), she had been a mailroom clerk-no particular gendered behavior could legitimately have been required of her.

149. As the plurality put it:

In saying that gender played a motivating part in an employment decision, we mean that, if we asked the employer at the moment of decision what its reasons were and if we received a truthful response, one of those reasons would be that the applicant or employee was a woman. In the specific context of sex stereotyping, an employer who acts on the basis of a belief that a woman cannot be aggressive, or that she must not be, has acted on the basis of gender. ... As for the legal relevance of sex stereotyping, we are beyond the day when an employer could evaluate employees by assuming or insisting that they matched the stereotype 
What if the masculine portion of the bind stood alone? What if only the feminine half of Hopkins's double bind had been dissolved? The language of the opinion may suggest that if Hopkins had been given the opposite sort of advice-if someone in the "masculine" position of manager in an accounting firm had instead been advised to walk less femininely, dress less femininely, talk less femininely, wear less makeup and a simple, short hair cut, take off her jewelry, and go to assertiveness training class-the finding of sex discrimination would have been much less clear. ${ }^{150}$ Similarly, the advice actually given Hopkins might more readily have passed Title VII muster if she had been a flight attendant, a nurse, or a fashion editor. If she had been in a job whose very requirements were coded feminine, she might have been required to display feminine characteristics, but this would not necessarily have been discriminatory sex stereotyping, since the same feminine characteristics-at least the psychological ones like "charm"151 - would presumably have been required of any holder of the job-male or female. I shall go on to explain in detail both how an unquestioning acceptance of the current gendered requirements for most jobs hurts women and why, under a disparate impact analysis, requiring such gendered characteristics (even if evenhandedly from both sexes) in the absence of business necessity is no less a violation of Title VII than requiring gender conformity.

\section{Smith, Strailey, and Effeminacy}

Before considering the implications of the prohibition on sex stereotyping for one of Hopkins's potential alter egos, the feminine woman whose employer requires her to be more masculine, let me first consider the doctrinally somewhat simpler but culturally perhaps more disturbing implications for another potential alter ego, the effeminate man. Assume such a man is told, as a feminine woman might be, but for quite different reasons, to be more masculine, not only in behavior (i.e., assertiveness training rather than charm school) but also in appearance. Assume as well, to complete the parallel to Hopkins, that he is not in a job conventionally gendered masculine,

associated with their group, for “" [i]n forbidding employers to discriminate against individuals because of their sex, Congress intended to strike at the entire spectrum of disparate treatment of men and women resulting from sex stereotypes." Hopkins, 490 U.S. at $250-51$ (citations and footnote omitted).

150. Brought at about the same time as Hopkins, and often linked with it in press reports, was an EEOC complaint by Brenda Taylor, an assistant state's attorney, reprimanded by her boss for wearing "short skirts, designer blouses, ornate jewelry and spike heels with colored hosiery" to court. See Lacayo, supra note 138, at 98 . He said she looked like a "bimbo." Id. For further discussion of cases of women penalized for behaving in a variety of stereotypically feminine ways at work, see infra Subsection IV.B.3. For a discussion of cases involving primarily issues of clothing and personal appearance, see infra Subsection IV.B.2 and text accompanying notes 235-39.

151. The fact that even in the most feminine of jobs males are unlikely to be told that their appearance, as distinguished from their behavior, should be more feminine, is one of several anomalies I shall discuss below. 
but one with few gendered expectations ${ }^{152}$ or conventionally coded feminine ${ }^{153}$, so that the advice given him to "walk more [masculinely], dress more [masculinely], [remove his] makeup, have his hair [cut], and wear [no] jewelry" is meant purely to enforce gender conformity rather than to meet a legitimate $^{154}$ job requirement imposed equally on members of both sexes. Demanding of a man that he wear no makeup or jewelry to work is culturally still quite acceptable, but a straightforward reading of Hopkins suggests that it may well also be illegal disparate treatment resulting from sex stereotyping. The argument that Title VII does not or should not protect men to the same extent as women is a particularly difficult one for opponents of the effeminate man to make. Not only is it settled law that Title VII protects both men and women from discrimination on the basis of sex, the case of the effeminate man would be a peculiar one in which to argue for an exception from the equal protection of men, because the very characteristics for which he is being penalized are those associated with women, the subordinated group the statutory language was principally designed to protect. If women were protected for being masculine but men could be penalized for being effeminate, this would, in my view, send a strong message of subordination to women, because it would mean that feminine qualities, which women are disproportionately likely to display, may legitimately be devalued although masculine qualities may not.

Even more than the situation of the feminine woman, that of the effeminate man may lie deep beneath the surface of the Hopkins decision. Of all those involved in the Hopkins case, dissenting Circuit Judge Williams seems to have been alone in realizing the possible innovation and breadth of the sex-stereotyping theory on which Hopkins prevailed:

The majority implicitly adopts a novel theory of liability under Title VII, but neither confronts the novelty of the theory nor gives it any intelligible bounds. ...

The theory is one of sexual stereotyping. An analysis grounding Title VII liability in such stereotypes may well be meritorious; but its

152. E.g., mail room clerk. See infra text accompanying notes 167-79 and 195-205 (discussing Smith v. Liberty Mut. Ins. Co., 569 F.2d 325 (5th Cir. 1978) and Dillon v. Frank, 58 Empl. Prac. Dec. (CCH) II 41,332 (6th Cir. 1992)).

153. E.g., nursery school teacher. See infra text accompanying notes 182-87 (discussing Strailey v. Happy Times Nursery Sch., reported as part of DeSantis v. Pacific Tel. \& Tel. Co., 608 F.2d 327 (9th Cir. 1979)).

154. Again, let me insist that not all gendered job requirements, even those imposed equally on members of both sexes, are necessarily legitimate. Many may themselves be the product of stereotyping and should have to be justified by business necessity because of their disparate impact on members of one or the other sex. Thus, again, it is not enough for an employer evenhandedly to require masculine traits from its employees, because to do so may have a disparate impact on women, who are disproportionately likely not to be masculine. The question the employer must then answer is whether these traits are demanded because the business actually requires them or for some other reason, such as, for example, merely because of the proxy bias that results because those who held the job in the past were male or merely because of the general cultural esteem in which certain masculine traits are held. See infra Part V. 
articulation would require care. No one argues that Congress intended entirely to overturn Justice Douglas's observation that "the two sexes are not fungible." Dismissal of a male employee because he routinely appeared for work in skirts and dresses would surely reflect a form of sexual stereotyping, but it would not, merely on that account, support Title VII liability. Nor, I suppose, does anyone contend that use of the feminine pronoun "she" to describe a female is a forbidden "evaluat[ion of] female candidates in terms of their sex."155

The language both of Title VII itself and of the Court in interpreting it does, however, suggest that, at least where sex is not a BFOQ, Congress has required an employer to treat the sexes as fungible. According to the plurality in Hopkins, for example:

Congress' intent to forbid employers to take gender [i.e., sex] into account in making employment decisions appears on the face of the statute. ... [T] he statute forbids an employer to "fail or refuse to hire or to discharge any individual, or otherwise discriminate with respect to his compensation, terms, conditions, or privileges of employment," or to "limit, segregate, or classify his employees or applicants for employment in any way which would deprive or tend to deprive any individual of employment opportunities or otherwise adversely affect his status as an employee, because of such individual's . . . sex." We take these words to mean that gender [i.e., sex] must be irrelevant to employment decisions. ${ }^{156}$

The opinion goes on to observe:

The only plausible inference to draw from th[e] provision [of a BFOQ for sex] is that, in all other circumstances, a person's gender [i.e., sex] may not be considered in making decisions that affect her. Indeed, Title VII even forbids employers to make gender [i.e., sex] an indirect stumbling block to employment opportunities. An employer may not, we have held, condition employment opportunities on the satisfaction of facially neutral tests or qualifications that have a disproportionate, adverse impact on members of protected groups when those tests or qualifications are not required for performance of the job. ${ }^{157}$

Attention to the language of the statute may therefore lead to something of a paradox - the stricter a constructionist one is, the more seriously one takes statutory language, the more inescapably one is led to a quite radical view of the effect of Title VII. For one need not go beyond the plain

155. Hopkins v. Price Waterhouse, 825 F.2d 458, 473-74 (D.C. Cir. 1987) (Williams, J., dissenting) (citations omitted).

156. Price Waterhouse v. Hopkins, 490 U.S. 228, $239-40$ (1989) (quoting 42 U.S.C. $\S \S 2000 \mathrm{e}-2(\mathrm{a})(1)-(2)(1988))$.

157. Id. at 242 (citations omitted). 
language of the statute to find explicit protection for Judge Williams's hypothetical "male employee who routinely appeared for work in skirts and dresses," at least if the skirts and dresses were of a sort the employer did not object to its female employees wearing. ${ }^{158}$ If this was in any doubt before Hopkins, ${ }^{159}$ the holding of that case that it constitutes impermissible sex stereotyping to suggest to a female employee that she "dress more femininely, wear makeup, have her hair styled, and wear jewelry" should make clear that sex-specific grooming standards violate Title VH. ${ }^{160}$ As I shall discuss below, the Court did not find as a matter of fact that Hopkins's appearance was appropriate for her sex; ${ }^{161}$ it held as a matter of law that it constituted sex discrimination for her employer to require that it be so.

It may therefore come as somewhat of a surprise to someone who pays attention to the niceties of doctrinal legal analysis (although, not, of course, to a student of cultural norms) to hear informed legal academics opine even after Hopkins that "discrimination against male job applicants who appear 'effeminate' is generally lawful, as is employment discrimination against cross-dressers."162 Two cases most squarely raise the issue of discrimination on the basis of effeminacy; both are circuit court cases from the mid-1970s

158. Thus, an employer, although apparently prohibited by the plain language of the statute (not to mention its interpretation in the theory of sex stereotyping) from imposing sex-specific grooming codes, may, of course, still set sex-neutral standards for professional appearance.

159. For example, because grooming codes were seen as de minimis; or because Title VII was seen to be limited to protection on the basis of immutable characteristics rather than something as easily changed as, e.g., one's clothing; or because equality was deemed to be assured by, in effect, separate but equal grooming codes for the two sexes, each of which was required to present an appropriate professional appearance. For discussion of these arguments and the cases that apply them, see infra text accompanying notes 208-26.

160. Of course, as a practical matter, that is insufficient reason to believe courts actually will extend Title VII protection to men in dresses. See infra Subsection IV.B.2. But for them to refuse to do so requires a bit of Iegal legerdemain and/or an acknowledgement that cultural attitudes trump statutory language and conventional legal reasoning. See, e.g., Karl E. Klare, Power/Dressing: Regulation of Employee Appearance, 26 NEW ENG. L. REV. 1395, 1401 (1992) (describing disparate grooming standards for men and women as simply result of sex stereotypes but acknowledging that "[c]ourts sometimes seem to believe that the foundations of civilization will crumble forthwith if men wear long hair or women wear pants").

For another, perhaps not unrelated, example of cultural attitudes generally prevailing over tightly reasoned legal arguments, consider, for example, the courts' responses to arguments that not to allow same-sex marriage constitutes sex discrimination. Here, as in the case of men in dresses, the response is typically less in the form of reasoned argument and more along the lines of "aw, c'mon, you can't be serious." See William N. Eskridge, Jr., A History of Same-Sex Marriage, 79 VA. L. REV. 1419, 1423 (1993) ("LL]iberal theory's hostility to same-sex marriage derives not from any internal logic but instead from cultural attitudes .... [J]ust as there was no neutral way for liberal theory to justify prohibiting interracial marriage yesterday, so there is no neutral way to justify prohibiting same-sex marriage today."). But see Baehr v. Lewin, 852 P.2d 44 (Haw. 1993) (finding prima facie case of sex discrimination in ban on same-sex marriage and remanding on question of compelling state interest).

161. Again, recall that the record is devoid of evidence as to what Hopkins looked like. See infra text accompanying note 208. Compare Hopkins, 490 U.S. at 228 with Adair v. Beech Aircraft Corp., 782 F. Supp. 558, 563 (D. Kan. 1992) (noting that successful plaintiff in Hopkins-like claim "presented a neat, matronly appearance" and "possesses the very essence of womanhood in the work place").

162. Klare, supra note 160, at 1420 (footnote omitted). Klare's is far from an eccentric view. See, e.g., Valdes, supra note 29, at 161 (claiming that "like Smith, Strailey remains 'good' law to this day"). And the abundance of post-Hopkins cases upholding employer prohibitions on cross-dressing as well as the dearth of cases squarely raising the issue of effeminacy unfortunately give support to the view. 
and therefore are arguably no longer good law in light of Hopkins. It would certainly be my considered judgment that Hopkins should in effect be seen as overruling them. But any man who thinks the answer is as simple as I think it ought to be should consider what would likely happen if he routinely appeared for work at a conventional job in a dress (or even a frilly pink blouse), high heels, makeup, and jewelry. ${ }^{163}$ If asked by a man fired for effeminate behavior whether he should win a Title VII challenge, I would unhesitatingly say yes; ${ }^{164}$ if asked if I thought he would win, I would have to express more doubts. I would, among other things, need to be assured either that he worked in one of those rare environments that prohibited discrimination on the basis of sexual orientation or that he was demonstrably not gay, because discrimination against effeminate gay men is generally overdetermined. Moreover, even if he were not at any risk of being fired for his sexual orientation, if his effeminate behavior were within his control, I would as a prudential matter advise him not to risk his job unless he were not only prepared to bring a test case, but also prepared to lose. Those post-Hopkins cases that have indirectly considered claims of discrimination against effeminacy in men - cases of workplace harassment of gay men, of cross-dressing by preoperative transsexuals or transvestites, or of less extreme violations of sex-specific grooming policies-have resulted in decisions against the male plaintiffs. ${ }^{165}$ Before examining such cases, as well as cases directly or indirectly raising claims of discrimination against feminine women, let me first comment briefly on the two earlier cases squarely on the point of effeminacy.

In the first, Bennie Smith, a Black male, ${ }^{166}$ applied for a job as a mail room clerk, but was turned down explicitly because, in the opinion of the interviewer, another Black male, Smith was "effeminate." 167 Here is how

163. See infra Subsection IV.B. 2 and cases cited therein (upholding dismissal of men for wearing, e.g., a pink pearl necklace).

164. That is, of course, if the behavior for which he was fired is tolerated or even encouraged in female employees. If it is not, the analysis becomes more complicated, as I will discuss below.

165. See, e.g., Terry v. EEOC, 35 Fair Empl. Prac. Cas. (BNA) 1395, 1397 (E.D. Wis. Dec. 10, 1980) (upholding firing of preoperative transsexual on grounds that "[t]he law does not protect males dressed or acting as females and vice versa").

166. The ways in which race intersects with effeminacy are important to consider, especially given that, of the small number of challenges brought by effeminate men, at least three were brought by Black men. For other examples of this intersection, see Williamson v. A.G. Edward \& Sons, Inc., 876 F.2d 69 (8th Cir. 1989), discussed infra note 221; and Richard Leiby, Clothed in Controversy: He's a 16-Year Old Gay Transvestite. Somehow, Anthony Slater Has Made Life Work, WASH. PoST, Sept. 7, 1994, at C1, discussed infra note 216. A full exploration of the intersection of race and effeminacy remains to be done, but, in a forthcoming essay, Kendall Thomas uses an analysis of attitudes toward James Baldwin to make intriguing and important observations on the subject. See Kendall Thomas, "Ain't Nothin' Like the Real Thing": Black Masculinity, Gay Sexuality and the Jargon of Authenticity, in REPRESENTING BLACK MEN (Marcellus Blount \& George Cunningham eds., forthcoming 1995). I am grateful to Professor Thomas for sharing his manuscript and further thoughts on the subject with me.

167. Smith v. Liberty Mut. Ins. Co., 569 F.2d 325, 326 (5th Cir. 1978). Once again, we can have no idea how "effeminate" Smith really was, in part because he did not appear in person at trial. The record of the case includes claims that the EEOC investigator assigned to the case found Smith's effeminacy 
the district court formulated Smith's claim of sex discrimination: "Plaintiff argues that it is forbidden under present law for an employer to consider a job applicant's affectional or sexual preference in hiring and that, therefore, the employer's election not to employ plaintiff because applicant (a male) appeared to be 'effeminate' constituted an unlawful discrimination." 168 In response, the court stated:

Plaintiff points out that defendant employed a female black applicant for the position sought by the plaintiff. He thus argues that the defendant accepted an employee presumably displaying effeminate characteristics resulting in plaintiff's having been discriminated against because he was a male.

The Court views the situation differently. It appears that the defendant concluded that the plaintiff, a male, displayed characteristics inappropriate to his sex, the counterpart being a female applicant displaying inappropriate masculine attributes. ${ }^{169}$

The court's own formulation ${ }^{170}$ puts Smith squarely within the rule applied in Hopkins-to refuse to hire someone simply for displaying "characteristics inappropriate to his sex" is indisputably to engage in impermissible sex stereotyping. ${ }^{171}$ Nevertheless, both the district and appeals courts ruled against Smith, each holding that, in their reading of the statute,

"quite pronounced" and that Liberty Mutual considered as evidence of effeminacy Smith's listing on his application "hobbies[] not normally associated with males (sewing)." Brief for Appellee at 9 n.7 (citation omitted). I am most grateful to Francisco Valdes for providing me with copies of the pleadings and briefs in Smith and Strailey. In the lower court, the employer contended that it had considered Smith's effeminacy disqualifying, not for its own sake, but as evidence of homosexuality. Id. at 18. Even if discrimination on the basis of homosexuality is not forbidden by Title VII, this should not be a sufficient defense because the employer used an imperfect and illegal proxy - the sex stereotype of "effeminacy"-for the unprotected trait of homosexuality. Even if most effeminate men are indeed gay, the employer's action, correctly analyzed, is thus no more permissible than, for example, to decline to hire any males because one is trying to avoid aggressive employees, and maleness is a fairly good proxy for aggressiveness. As it happens, Smith himself contended that he was not gay at all, but a happily married straight man. Brief for Appellant at 20 n.7.

168. Smith v. Liberty Mut. Ins. Co., 395 F. Supp. 1098, 1099 (N.D. Ga. 1975).

169. Id. at 1099 n.2. The circuit court credits the district court with heroic efforts to make sense of Smith's claim. Smith, 569 F.2d at 328. It cites excerpts from the trial transcript, ending with the district judge's conclusion that Smith "wasn't employed because the interviewer didn't like this particular person, white, black, male or female, he just didn't like him because he was [sic], in his view, gave evidence of the characteristics of sexual aberration." Id. at 328 n.4.

170. The circuit court's formulation is to the same effect:

Liberty Mutual concedes that Smith's application for employment was rejected because the interviewer considered Smith effeminate. Smith argues that the law forbids an employer to reject a job applicant based on his or her affectional sexual preference.

....

Here the claim is not that Smith was discriminated against because he was a male, but because as a male, he was thought to have those attributes more generally characteristic of females and epitomized in the descriptive "effeminate."

Smith, 569 F.2d at 326, 327. The court further described Smith as having claimed he was discriminated against because he was "too womanly" before holding that "Title VII cannot be strained to reach the conduct complained of here." Id.

171. Again, recall the language of Hopkins cited supra text accompanying note 155. 
it is permissible to discriminate both on grounds of nonconformity to gender roles and on the basis of sexual orientation. Thus, even if Hopkins makes clear that Smith should have been protected from sex stereotyping, the result in Smith would not change because, to the extent he was (also?) ${ }^{172}$ not hired because of his orientation, something most employers can still legally take into account, his failure to get the job was overdetermined.

Interestingly, after an elaborate disquisition on the virtues of liberty, ${ }^{173}$ in which it defended maximum employer freedom consistent with statutory restrictions, the district court insisted that the statutory purpose cannot be "thwart[ed] . . . through the application of employment standards, to male and female alike, which, in application, deny employment to one sex or the other." 174 According to the district court:

It might sound like legality to announce a program of hiring without regard to sex all persons whose facial hair does not, unshaven, grow to a visually perceptible length in two weeks, but who could deny that such an employer effectively discriminated against males? Indeed, the reverse of the case under consideration would not, the Court apprehends, be lawful. Were an employer to offer employment to all persons, men and women alike, who were effeminate, would such employer not discriminate against males? Would this not be so even though, admittedly, there would be some males who would qualify and presumably, be given employment on an equal basis with competing female applicants?

So the courts knock down sham and subterfuge to see to it that the mandate of the law be carried out. Yet the limit of the mandate is as important as its content. Beyond the limit of this law is freedom of action and freedom is to be protected with no less vigor than enforcement of a statute. ${ }^{175}$

Especially given its unwillingness to prohibit discrimination on the basis of the violation of sex stereotypes, this is a particularly intriguing position for the district court to take. Although its view of Title VII is less expansive than the Hopkins Court's with respect to one form of sex stereotyping-the stereotyping of individual employees-it may possibly be more expansive when it comes to another-the stereotyping of jobs. It seems, therefore, that

172. Because both Smith courts so thoroughly conflate the gender and orientation claims-indeed, when they describe the plaintiff as manifesting "the characteristics of sexual aberration," Smith, 569 F.2d at 328 , it is quite unclear whether they are referring to homosexuality or mere aberration from masculine gender roles-it is difficult to say whether they are, in their own view, distinguishing between two grounds for discrimination or seeing them as the same. As with Strailey, the insertion of references to homosexual orientation into discussions of claims that could have been framed and disposed of entirely in terms of gender-role behavior is left somewhat mysterious as an analytical matter, although, of course, perfectly understandable in terms of cultural expectations. See infra text accompanying notes 182-87.

173. Smith v. Liberty Mut. Ins. Co., 395 F. Supp. 1098, 1099-1100 (N.D. Ga. 1975).

174. Id. at 1101 .

175. Id. 
if one were to combine the protections offered by the Supreme Court's holding in Hopkins with those set forth in the above dicta, one might produce something very much like the approach to discrimination on the basis of gendered characteristics outlined in this Article. Hopkins (unlike Smith) prohibits employers from requiring of employees one sort of gender conformity (to their biological sex) and the Smith dicta (arguably unlike Hopkins) ${ }^{176}$ prohibit them from requiring another (to the gendered characteristics the employer makes a requirement for the job).

Indeed, although I believe the Smith court is correct in its intuition that hiring only ${ }^{177}$ those who are effeminate (i.e., feminine) would constitute discrimination against males-indeed although a central claim in this Article is along these lines-I do not think the matter is as straightforward as the court suggests. For, contrary to the implicit assumption behind the Smith dicta, I do not think that all forms of even categorical discrimination in favor of the feminine necessarily violate the Title VII rights of males. This is because sometimes business necessity will in fact justify the requiring of certain gendered characteristics-some jobs do legitimately require assertiveness; in others, "charm" may be required and assertiveness be a drawback. ${ }^{178}$ So long as the gendered characteristics are narrowly jobrelated and consistent with business necessity, using them as a hiring criterion should not violate Title VII, but courts should, under conventional disparate impact analysis, take on where necessary the task of determining whether business necessity indeed requires these gendered characteristics.

In the particular case of Smith, however, because the job had few if any gendered expectations, ${ }^{179}$ the only gender issue the court had to face

176. I am here once again referring to the Hopkins Court's unquestioning acceptance of the proposition that it was legitimate for Price Waterhouse to require masculine characteristics from Ann Hopkins and other partnership candidates. Of course, given that she more than amply demonstrated these characteristics, 490 U.S. at 234-35, there was no need for the Court to question the firm's having required them. And I would have every hope, given that even in Hopkins the Court reaffirms its commitment to disparate impact analysis in its general outline of the statutory prohibitions, that if confronted with an appropriate case, the Court, consonant with the Smith dicta and the argument of this Article, would hold that to require masculine traits of employees on a sex-neutral basis has a disparate impact on women, just as to require feminine behavior would have a disparate impact on men-so that, in either case, the practice must be justified by business necessity.

177. See supra text accompanying note 175 . The court's formulation is sloppy. The court presumably means only (not all) those who are effeminate or don't have facial hair-no employer would possibly hire all such applicants and to do so would only raise questions of discrimination if the employer also did not hire people who lacked the relevant characteristic.

178. Thus, the Smith dicta are in some tension with cases like Diaz in which an employer of flight attendants does hire only people who are feminine; the Diaz court says this is an appropriate hiring criterion, although an insufficient reason to make sex a BFOQ because of the one male in a thousand who may display the relevant qualities. See Diaz v. Pan Am. World Airways, 442 F.2d 385, 388-89 (5th Cir. 1971).

179. Indeed, given the mail clerk job's status, it is far more likely to require feminine than masculine qualities. This is not simply because it is often performed by females (note that Smith's replacement was a woman), but because, like many low-status jobs within organizations, it requires qualities such as deference and helpfulness rather than assertive leadership. See, e.g., Fogg v. New Eng. Tel. \& Tel., 346 F. Supp. 645,649 (D.N.H. 1972); see also infra note 247. This is not to say that there is no connection 
directly was that of the employer's requirement that gender conform to sex-that Smith, a male, not be effeminate. As noted above, although both the district and circuit courts in Smith discussed and rejected the theory of sex stereotyping later applied by the Supreme Court in Hopkins, they both seem to have folded Smith's claim along these lines into a claim that he was discriminated against on the basis of sexual orientation, something from which they held Title VII also did not protect him. Thus, discrimination against the effeminate man may be overdetermined, and effeminacy conflated with gayness, something which, among other things, may well help account as a practical matter for the scarcity of post-Hopkins claims by effeminate men. The close link made between effeminacy and homosexual orientation in men was reinforced when other courts treated Smith as dispositive of the question whether sexual orientation discrimination is covered by Title VII. For example, when a woman claimed that her employer discriminated between homosexuals on the basis of sex, judging "females, but not males ... on the basis of their sexual preferences," "180 a court relied on Smith in rejecting her claim. According to the court, "[s]ubstitute "lesbian mannerisms' for 'effeminate mannerisms' and this case would be identical to Smith."181

In the most dramatic example of this link between discrimination on the basis of gender and of sexual orientation, Strailey v. Happy Times Nursery School, the case of a male nursery school teacher fired for his "effeminate appearance," specifically the wearing of an earring, was lumped together in a circuit court opinion with two unrelated cases explicitly and exclusively raising claims of discrimination on the basis of sexual orientation. ${ }^{182}$ The

between the predominant sex in a job category and the gendered expectations of the job. But, as noted elsewhere, the relation between cause and effect of such expectations can be difficult to disentangle. In addition to the examples of physicians, accountants, and sales personnel discussed elsewhere, consider the job of secretary-formerly male, masculine, and high status, now female, feminine, and low status. Did the gendered requirements of the job change because the sex of its occupants changed, vice versa, or as a result of some more complicated process?

180. Valdes v. Lumbermen's Mut. Casualty Co., 507 F. Supp. 10, 11 (S.D. Fla. 1980).

181. Id. at 12. Query what the court imagines "lesbian mannerisms" to be. The court "notes that this issue could probably be resolved more simply if Lumberman's [sic] could show that they discriminate against both male and female homosexuals." Id. at 13 n.*; $c f$. RICHARD A. POSNER, SEX AND REASON 304 (1992) (describing lesbians as "the opposite of effeminate").

182. DeSantis v. Pacific Tel. \& Tel. Co., 608 F.2d 327 (9th Cir. 1979). This is the leading case on Title VII's application to sexual orientation. The other two actions were brought on quite different facts and theories of liability than Strailey. All three actions were dismissed for failure to state a claim under Title VII, a result consistent with all subsequent cases that have tried to argue that Title VII protects against discrimination on grounds of sexual orientation. The defendant in the other two cases was Pacific Telephone and common to both cases were the claims that (1) to treat, for example, a male who prefers male sexual partners differently from a female who prefers male partners was to use different employment criteria for men and women, something Title VII prohibits; and (2) given that discrimination against those who associated with blacks had been held to violate Title VII, "analogously discrimination because of the sex of the employee's sexual partner should constitute discrimination based on sex." Id. at 331. One of the other cases was brought by two lesbian lovers harassed and then fired because of their relationship. DeSantis himself and other gay male telephone company employees additionally alleged that, because gay males were more numerous and more visible than lesbians, discrimination on the basis of homosexual 
court began its opinion by saying, "Male and female homosexuals brought three separate federal district court actions claiming that their employers . . . discriminated against them in employment decisions because of their homosexuality." 183 But when it went on to recite the facts of Strailey, it described a claim of discrimination very much like that of Ann Hopkins, one based on failure to comply with stereotypical gender-role expectations, not directly on sexual orientation.

Several things are worthy of comment in the court's discussion. First, Strailey was a nursery school teacher, a job stereotypically gendered feminine, in a way that those of accountant ${ }^{184}$ and manager are gendered masculine. On its face, therefore, Strailey's case, even more than Smith's, is the mirror image of Hopkins's. In the latter, a woman gendered masculine in a job also gendered masculine was nevertheless required to be more feminine in order

orientation had a disparate impact on men. Id. at 330. In light of Dillon v. Frank, 58 Empl. Prac. Dec. (CCH) II 41,332 (6th Cir. 1992), see infra text accompanying notes 195-204, it is worth noting that while DeSantis alleged discriminatory failure to hire, his coplaintiffs claimed they had been forced to quit as the result of continual harassment by coworkers and supervisors. DeSantis, 608 F.2d at 328.

183. DeSantis, 608 F.2d at 328. The court's discussion of Strailey is worth quoting in full: Appellant Strailey, a male, was fired by the Happy Times Nursery School after two years' service as a teacher. He alleged that he was fired because he wore a small gold ear-loop to school prior to the commencement of the school year. He filed a charge with the Equal Employment Opportunity Commission (EEOC) which the EEOC rejected because of an alleged lack of jurisdiction over claims of discrimination based on sexual orientation. He then filed suit on behalf of himself and all others similarly situated, seeking declaratory, injunctive, and monetary relief. The district court dismissed the complaint as failing to state a claim under either Title VII or $\S 1985(3)$.

$\cdots$

E. Effeminacy

Appellant Strailey contends that he was terminated by the Happy Times Nursery School because that school felt that it was inappropriate for a male teacher to wear an earring to school. He claims that the school's reliance on a stereotype-that a male should have a virile rather than an effeminate appearance-violates Title VII.

In Holloway this court noted that Congress intended Title VII's ban on sex discrimination in employment to prevent discrimination because of gender, not because of sexual orientation or preference. Recently the Fifth Circuit similarly read the legislative history of Title VII and concluded that Title VII thus does not protect against discrimination because of effeminacy. Smith v. Liberty Mutual Insurance Co., 569 F.2d at 326-27. We agree and hold that discrimination because of effeminacy, like discrimination because of homosexuality or transsexualism, does not fall within the purview of Title VII.

Id. at 328, 331-32 (citations and footnote omitted).

In Strailey's case, as Francisco Valdes's research has shown, the issue of homosexuality was introduced by his attomey, who, notwithstanding that the employer had made no mention of Strailey's orientation in taking action against him, alleged in the complaint that Strailey was fired because he was "a homosexual and failed to present a proper male image." The attomey explained to Professor Valdes, "I knew that they objected to his earring, and I inferred that they objected to his homosexuality because of that." In the attorney's view, the "'school was generally displeased with Mr. Strailey's image, his general effeminacy," and feared parental objection to its employment of gay teachers. Valdes, supra note 29, at 154-55 (citing interview with Strailey's attomey). Although it did consolidate Strailey's case with others raising only sexual orientation claims, the Ninth Circuit appeared to distinguish Strailey's claim of "discrimination because of effeminacy" from one for "discrimination because of homosexuality" in its opinion. DeSantis, 608 F.2d at 331-32.

184. At least in this country, although my colleague Paul Stephan informs me that in the Soviet Union and the Eastern European communist world, where dealing with private money was viewed as less prestigious, the job was held predominantly by women and was gendered feminine. 
to conform to gender-role stereotypes; in the former, a man gendered feminine in a job also gendered feminine was nevertheless required to be more masculine to conform to gender role stereotypes. In both cases, whatever deeper gender expectations may have been at issue, personal appearance, specifically the wearing of jewelry, was at the heart of the employer's explicit objections: Hopkins was in effect told to put on the earring Strailey was fired for wearing.

Second, while Strailey was concededly gay (while it may, in the 1970s, even have been an accurate stereotypical generalization that men who wore earrings tended to be gay and to be deliberately signaling that fact by their choice of jewelry), Strailey's sexual orientation can be seen to have no bearing on his Title VII claim, notwithstanding the court's and the EEOC's assumptions to the contrary. One might respond that precisely because Strailey was a nursery school teacher, his sexual orientation, as well as his gender-role behavior, was of great importance indeed. Even quite apart from fears of pederasty, there is a legitimate expectation that teachers be role models, and neither gender bending nor homosexuality would be seen as setting a suitable example. ${ }^{185}$ Strailey, however, was fired simply for wearing an earring, and for wearing it "prior to the commencement of the school year." 186 He had been in the employ of the school for two years when he was fired; surely his employers, if they had been concerned about his orientation, would have taken action long before. And if they were concerned, quite apart from homosexual issues, about the potentially pernicious influence of a gender-bending role model on children, why was he fired only for behavior engaged in out of their presence? Moreover, if his generally "effeminate appearance" was a concern-either because of its homosexual or its gender-transgressive implications-why, again, would his employers have waited so long or given so apparently flimsy a reason for terminating him? They could hardly have been seeking a pretext, given that they could legally invoke both orientation and gender-role transgression as grounds for his dismissal. Consider, as well, that many people do get fired for violating sex-specific grooming norms-for wearing earrings, or pink pearl necklaces, or makeup-not necessarily in a habitual and therefore clearly insubordinate way, but often just once or twice. ${ }^{187}$

185. Thus, in upholding the postoperative firing of a male-to-female transsexual teacher because of the potentially disruptive impact on students, one court accepted the testimony of the employer school's expert witness, Dr. Charles Socarides, that "one of the major things in teaching is that we learn through identification with the teacher . . . And, boys not only learn their lessons in school but they learn how to be men from their teachers." In re Grossman, 316 A.2d 39, 45 (N.J. Super. Ct. App. Div. 1974). But see Jatczak v. Ochburg, 540 F. Supp. 698, 702-05 (E.D. Mich. 1982) (rejecting BFOQ of maleness for job as child care worker in facility for troubled youth, notwithstanding claim that young men needed male role model).

186. DeSantis, 608 F.2d at 328.

187. See supra Subsection IV.A.1. 
Having set forth the paradigmatic case of Hopkins and contrasted it with two parallel cases of discrimination against effeminate men, I shall now proceed to ring the changes on gender in the law of discrimination, in its interaction with sex, sexual orientation, and job requirements.

\section{B. Applying Hopkins}

\section{Sexual Orientation and Hostile Environments}

Given that both Smith and Strailey conflate discrimination on the basis of effeminacy with sexual orientation discrimination, one of the questions one might ask about the protection of effeminate men is why their cases, if not overruled, should not be viewed simply as part of the struggle to recognize sexual orientation as a forbidden ground for discrimination, rather than also of more direct concern to the questions of sex discrimination central to feminist jurisprudence. First, because feminine gender in men and gay male sexual orientation are far from perfectly overlapping categories, there are effeminate men who are not gay as well as gay men who are not effeminate. ${ }^{188}$ Even if legislative protection from discrimination on grounds of homosexuality could be achieved, this would not solve the problem of effeminate heterosexuals like Bennie Smith. Moreover, even with protection for sexual orientation, employers may still discriminate between effeminate and non-effeminate gay as well as straight males. ${ }^{189}$ There is ample historical precedent for this sort of discrimination in the distinction made in law and in life between men who took the active and passive roles in homosexual intercourse. ${ }^{190}$ As I shall argue with reference to sexual harassment cases below, a particular emphasis on their role as the receptive partner in fellatio is, for example, a common thread running through the denigration both of gay men and of women generally, and may be indicative of more systematic denigration of persons and things coded feminine in the workplace.

The differential pull of feminine gender in males toward sexual orientation may, as suggested above, explain why there have been since Hopkins very few suits by males arguing that sex stereotyping on the basis

188. See, e.g., Hunter, supra note 79. Consider, also, the Saturday Night Live character Lyle, the Effeminate Heterosexual.

189. Indeed, there is reason to suppose such discrimination may take place within the gay community so that even an extremely gay-friendly workplace-one run by gay men, for example-might be guilty of discrimination against the effeminate. See, e.g., SEDGWICK, supra note 77, at 157 (explaining gay movement's lack of attention to "issues concerning effeminate boys" and "the marginal or stigmatized position to which even adult men who are effeminate have often been relegated in the movement" as the result of a need to "begin to theorize gender and sexuality as distinct").

190. See, e.g., CANTARELla, supra note 29, at 112-13, 175-81; CHAUNCEY, supra note 29, at 47-48; Martha C. Nussbaum, Platonic Love and Colorado Law: The Relevance of Ancient Greek Norms to Modern Sexual Controversies, 80 VA. L. REV. 1515, 1547-48, 1585-90 (1994). 
of effeminacy constitutes sex discrimination, none of them successful. It may be because at the moment it is permissible almost everywhere to discriminate on the basis of sexual orientation that the firing of an effeminate man is often overdetermined. Even if it is not permissible to fire him for his effeminacy, it may be permissible to fire him for the sexual orientation that is presumed and may in fact go with it." ${ }^{191}$ Frank Valdes has called this the "sexual orientation loophole" to claims of sex discrimination. ${ }^{192}$

True to this tendency to conflate effeminacy and homosexual orientation in males, both what scholarly commentary and what little case law ${ }^{193}$ there has been directly raising the potential application of a Hopkins-style sexstereotyping analysis to males has focused on issues related to sexual orientation. $^{194}$ Dillon v. Frank ${ }^{195}$ represents a rare recent attempt by a male to invoke such an analysis. A fellow U.S. Postal Service employee "began calling Dillon 'fag' and saying that 'Dillon sucks dicks."196 The abuse culminated in a physical assault on Dillon, for which his coworker was fired. But "[w]hat had begun as a one-man band expanded into a full orchestral assault of verbal abuse. Other employees used similar epithets. Graffiti ... . appeared [at the work site] . . . informing the mail center that 'Dillon sucks dicks' and 'Dillon gives head."'197 According to the court that denied Dillon's sexual harassment claim, "Although the exact language is not essential to the resolution of the case, we include a sample to demonstrate the strength of Dillon's analogy to cases involving heterosexual hostile environment harassment." 198 The Dillon court "define[d] 'sex stereotyping' to mean the assigning of certain behavioral characteristics as appropriate for

191. Cf. United States v. Smith, 28 C.M.R. 782, 783 (A.B.R. 1959) (upholding judge advocate's conclusion that charge of homosexual sodomy was true "partly on the evidence and partly because accused had a falsetto voice and an effeminate manner").

192. Valdes, supra note 29 , at 18.

193. A few of the more recent transsexual/transgender cases, although not squarely raising the issue of effeminacy or citing Hopkins, do implicitly raise related issues. Hopkins notwithstanding, these cases hold that requiring men to conform to certain sex stereotypes may not violate the law. The majority of these cases uphold prohibitions on cross-dressing and will be discussed infra Subsection IV.A.2. In Underwood v. Archer Management Servs., Inc., 857 F. Supp. 96, 98 (D.D.C. 1994), the court held it to state a claim of discrimination on the basis of personal appearance, prohibited by D.C. statute, but not on the basis of sex or sexual orientation, for the defendant to "discharg[e] Plaintiff Underwood because she is a transsexual and retains some masculine traits." Underwood had claimed that the defendant had "discriminated against her on the basis of conditions associated with her transsexuality-namely, her gender." Id.

194. A number of law review articles and notes have raised the possibility of using Hopkins in the context of an argument for protection against discrimination on grounds of sexual orientation. See, e.g., Samuel A. Marcosson, Harassment on the Basis of Sexual Orientation: A Claim of Sex Discrimination Under Title VII, 81 GEO. L.J. 1, 24-28 (1992); David R. Wade, Women Denied Partnerships Revisited: A Response to Professors Madek and O'Brien, 8 HofsTRA LAB. L.J. 81, 120-24 (1990); I. Bennett Capers, Note, Sex(ual Orientation) and Title VII, 91 ColuM. L. REV. 1158, 1175, 1184 (1991); Marie Elena Peluso, Note, Tempering Title VII's Straight Arrow Approach: Recognizing and Protecting Gay Victims of Employment Discrimination, 46 VAND. L. REV, 1533, 1539 n.32, 1548 n.125 (1993).

195. 58 Empl. Prac. Dec. (CCH) I 41,332 (6th Cir. 1992).

196. Id. at 70,102 .

197. Id.

198. Id. at 70,102 n.1. 
women or for men, but not for the other sex."199 Citing Hopkins, however, the court wrote:

Dillon contended that he was subjected to such stereotyping in that he was not deemed "macho" enough by his co-workers for a man, and that the verbal abuse resulted from this stereotyping.

....

. . . His argument is that but for his being male, he would not have been abused. We find this argument unpersuasive, primarily because he has not shown that his co-workers would have treated a similarly situated woman any differently. Dillon's argument must presume that the abuse was either directed at his supposed homosexuality or at specific sexual practices (such as anal sex or fellatio). . . . Dillon has not shown such unisexual oppression: he has not argued that a lesbian would have been accepted at the Center, nor has he argued that a woman known to engage in the disfavored sexual practices would have escaped abuse. See Porta v. Rollins Envtl. Serv. .. . (graffiti alleging "Judy sucks Bernie's dick" part of sexual harassment claim). Without such a showing, his claim to have been discriminated against because he is male cannot succeed. ${ }^{200}$

The court went on to observe:

Price Waterhouse v. Hopkins does not direct a different result. Price Waterhouse was not a hostile environment case. It involved . . . [an] allegation "that gender played a part in a particular employment decision." Because of this difference . . . , we do not read the Court to mean that any treatment that could be based on sexual stereotypes would violate Title VII.

....

... In our case there is no evidence provided that Dillon's co-workers justified their outrageous behavior based on, or accompanied it with remarks indicating, a belief that his practices would be acceptable in a female but unacceptable in a male.

Further, the Court emphasized the "intolerable and impermissible Catch-22" in the stereotyping in that case. A desirable trait (aggressiveness) was believed to be peculiar to males. If Hopkins lacked it, she would not be promoted; if she displayed it, it would not be acceptable. In our case, Dillon's supposed activities or characteristics simply had no relevance to the workplace, and did not place him in a "Catch-22."

Thus, the discussion of sexual stereotyping in Price Waterhouse does not support a holding that discrimination "on account of sex" was involved in this case. ${ }^{201}$

199. Id. at 70,105 n.3.

200. Id. at 70,105-08.

201. Id. at 70,108-09 (citations omitted). 
Again, several things are worthy of note in the court's analysis. First, the court found the doubleness of Hopkins's bind dispositive, erroneously in my view. Second, a large body of case law, including the single case cited by the court, indicates that "if [plaintiff] had been a woman, the conduct alleged in [this] case would 'unquestionably have constituted sexual harassment ...."202 Not only are vulgar suggestions that women perform oral sex a staple of sexual harassment cases, they are also often coupled with disparaging comments about women's job-related abilities. This is, for example, true of the case cited by the Dillon court, in which, in addition to being accused of "suck[ing] Bernie's dick," plaintiff was told, "What do you know, you're a woman.",203 Indeed, a large number of sexual harassment cases brought by women allege precisely this sort of verbal abuse. If both women and gay men in the workplace are systematically harassed for their receptive role in fellatio, to all appearances for the purpose and often with the effect of driving them out of the workplace ${ }^{204}$ and leaving it to "real men" (the sort who see themselves as always taking the active/masculine role in bed and elsewhere), this, I would argue, is a form of gender discrimination against the feminine, one with serious effects on the job performance and security of its victims. And while current sexual harassment doctrine gives women a remedy against such abuse, the remedy should be extended to those

202. Mogilefsky v. Superior Court, $20 \mathrm{Cal}$. App. 4th 1409, 1416 (1993) (criticizing another same-sex harassment case for "failure to mention, much less discuss, this double standard").

203. Porta v. Rollins Env't Servs., 654 F. Supp. 1275, 1279 (D.N.J. 1987). For further examples coupling a disparagement of women's job performance with a crude reference to oral sex, see Lipsett $v$. University of P.R., 864 F.2d 881, 888 (1st Cir. 1988) (reversing summary judgment for defendant where, inter alia, plaintiff was told that women should not be surgeons and was nicknamed by her male coworkers “'Selastraga,' translated literally to mean 'she swallows them"”); Robinson v. Jacksonville Shipyards, 760 F. Supp. 1486, 1498-99 (M.D. Fla. 1991) (finding plaintiff sexually harassed where taunts and graffiti directed at her included "there's nothing worse than having to work around women" and "lick me you whore dog bitch, and eat me"); Morris v. American Nat'1 Can Corp., 730 F. Supp. 1489, 1491 (E.D. Mo. 1989) (finding sexual harassment where, inter alia, workplace was festooned with sexually explicit pictures, including one of a nude woman captioned, "You should be doing this instead of a man's job," and graffiti claiming "Jackie blows heads"); Carlin Meyer, Feminism, Work and Sex: Returning to the Gates 13-14 (delivered at conference on Direction and Distortion: The Centrality of Sexuality in the Shaping of Feminist Legal Theory, Columbia University, June 1994) (unpublished manuscript, on file with author). Meyer recounts in detail the harassment of each plaintiff in the settled Stroh's litigation. Although the Stroh's harassment is extensive and varied, two common themes appear to be a general denial of women's ability to perform certain jobs and assertions that particular women employees perform oral sex. Interestingly, it is the sexualized half of the abuse that is generally seen to raise the stronger sexual harassment claim. Notwithstanding that statements about women's inability to do a job go to the heart of the purpose of Title VII, it is the crude sexual remarks that courts seem to take more seriously. For a further example of harassment of a homosexual with belittling, feminizing references, see Carreno v. IBEW Local No. 226, 54 Fair. Empl. Prac. Cas. (BNA) 81, 81 (D. Kan. 1990) (rejecting sexual harassment claim by homosexual employee whose coworkers called him "Mary" as well as "faggot").

204. Possibly in part out of a notion that they will contaminate the workplace. See supra note 110. Supporters of an all-male Citadel similarly viewed Shannon Faulkner's very presence there as contaminating. A cadet testified in deposition that Faulkner would be "a toxic kind of virus," Susan Faludi, The Naked Citadel, New YORKER, Sept. 5, 1994, at 65, and the day of her departure was described as "cleansing day for the Citadel" by the former president of Women in Support of the Citadel, whose group sold "Save the Males" bumper stickers to defray The Citadel's legal expenses. Citadel's First Female Dropout "Miserable," S.F. EXAMINER, Aug. 20, 1995, at A1. 
males taunted because they are perceived to behave in one or another feminine way. ${ }^{205}$

\section{Men in Dresses (or "Rebel-Rousing, Skirt-Wearing Persons") 206}

It is difficult to see how disparate grooming standards for the two sexes can survive Hopkins's holding that it constitutes evidence of sex discrimination to suggest to a female employee that she "dress more femininely, wear make-up, have her hair styled, and wear jewelry." "207 Let me stress again that the record before the Court gives no clue of what Ann Hopkins actually looked like; for all it tells us, her habitual attire might have been a button-down shirt, a rep tie, a man-tailored pinstripe pantsuit, and a buzz cut. ${ }^{208}$ The case does not find as a matter of fact that her appearance was appropriate for her sex; it holds as a matter of law that it constitutes sex discrimination for her employer to require that it be so.

The most influential of the many lower court endorsements of disparate grooming standards predate the Supreme Court's more expansive prohibitions of sexual stereotyping and thus relied on reasoning that is no longer good law. One of the leading cases, Willingham v. Macon Telegraph Publishing Co., reasons as follows: "The primary premise of [plaintiff]'s position is that

205. For another example of a court failing to protect a man (from the facts probably not a gay man) from abuse on the basis of feminine traits his coworkers perceived and resented in him, see Goluszek v. Smith, 697 F. Supp. 1452 (N.D. Ill. 1988). The facts depict Goluszek as an awkward homebody, with little sexual experience, easily flustered and made uncomfortable by talk of sex. His coworkers, sensing this, mercilessly tormented him with taunts insisting he should get married and/or be anally penetrated. The court conceded that if Goluszek had been a woman he would have had a classic sexual harassment case, but it held that:

Goluszek was a male in a male-dominated environment. In fact, ... . every one of the figures

in this story was a male. The argument that Goluszek worked in an environment that treated males as inferior consequently is not supported by the record. In fact, Goluszek may have been harassed 'because' he is a male, but that harassment was not of a kind which created an anti-male environment in the workplace.

Id. at 1456. Of course, I would argue that Goluszek is a victim of gender, not sex, harassment: He is, if not an effeminate man, then a man tormented on the basis of characteristics coded feminine. For a similar analysis of Goluszek, see Abrams, supra note 39, at 2513-17.

206. See Johnson v. Transp. Agency, 480 U.S. 616, 624 n.5 (1986) (upholding affirmative-action thumb on scales in favor of female candidate for road dispatcher who came in slightly behind man in subjective scoring of applications and noting that one of two promotion panel members described her as "a 'rebel-rousing, skirt-wearing person"" while the other refused to issue her coveralls issued to her male coworkers).

207. Price Waterhouse v. Hopkins, 490 U.S. 228, 235 (1989).

208. Cf. JOHN T. MOLLOY, THE WOMAN'S DRESS FOR SUCCESS BOOK 29 (1977) (illustrating "Imitation Man Look" and admonishing "[n]ever wear-[m]an's fedora[, s]hirt and tie[, p]instripe or chalkstriped [pants] suit"). An Imitation Man style of dress has also been associated with lesbians, particularly butch lesbians. See, e.g., SimoNe DE BEAuvorR, THE SECOND SEX 404 (H.M. Parshley ed. \& trans., Alfred A. Knopf 1953) (1952); Patricia A. Cain, Lesbian Perspective, Lesbian Experience, and the Risk of Essentialism, 2 VA. J. SOC. POL'Y \& L. 43, 44 n.5 (1994). No explicit suggestion of lesbianism was attached to Hopkins, however. This was perhaps because she was visibly married. See Hopkins v. Price Waterhouse, 825 F.2d 458, 461 (D.C. Cir. 1987). She came to Price Waterhouse to avoid an antinepotism rule at the firm that employed both her and her husband, and her husband's partnership in a rival firm caused administrative obstacles to her partnership candidacy. Id. at 461-62. 
'sex plus' must be read to intend to include 'sex plus any sexual stereotype' and thus, since short hair is stereotypically male, requiring it of all male applicants violates Sec. 703."209 The court went on to hold

\begin{abstract}
that [the] objective [of maximizing individual freedom by eliminating sexual stereotypes] may not be read into the Civil Rights Act of 1964 without further Congressional action. Private employers are prohibited from using different hiring policies for men and women only when the distinctions used relate to immutable characteristics or legally protected rights. ${ }^{210}$
\end{abstract}

Commentators have criticized Title VII hair-length cases, mostly 1970 s vintage, ${ }^{211}$ as indefensible in light of Supreme Court pronouncements on disparate treatment. ${ }^{212}$ The Willingham trial court clearly set out the items

209. 507 F.2d 1084, 1089 (5th Cir. 1975).

210. Id. at 1092. Outside Title VII, the prison context brings out somewhat different justifications for hair-length regulations, with courts in these cases actually endorsing the sort of stereotyping held to be discriminatory in other contexts. Thus, one court upheld a requirement that male prisoners keep their hair above collar length:

[S]ince men and women differ physically and psychologically, ... prison administrators are free to give differential treatment to male and female inmates based on perceived natural and practical differences. In the instant case the penal authorities could reasonably conclude that the greater aggressiveness and disposition toward violent action frequently displayed by male prisoners makes institutional security, maintenance of internal discipline and prevention of homosexual attacks-penal goals which the hair regulation furthers-a much greater problem in the men's prisons than in the women's correctional institution. Likewise the greater importance of personal appearance to women than men largely eliminates any hygienic problems with respect to long hair of female inmates. In short, there is a validating relationship between the varying behavioral patterns of the two sexes and the regulatory distinction between the sexes with respect to hair length.

Poe v. Werner, 386 F. Supp. 1014, 1020-21 (M.D. Pa. 1974); accord Wilson v. Schillinger, 761 F.2d 921, 926 (3d Cir. 1985).

Even more troubling than the prison cases are recent cases on school grooming codes. While the prison cases use reasoning based on stereotypes as justification for sex-specific grooming codes, these school cases hold that the very desire to reinforce such stereotypes may itself without more serve as a sufficient justification for the codes. See, e.g., Harper v. Edgewood Bd. of Educ., 655 F. Supp. 1353, 1355 (S.D. Ohio 1987) (rejecting First and Fourteenth Amendment sex discrimination claims by brother and sister prevented from attending high school prom dressed in clothing of the opposite sex, because dress codes were "reasonably related to the valid educational purpose[] of teaching community values"); Hines v. Caston Sch. Corp., 651 N.E.2d 330, 334 (Ind. Ct. App. 1995) (holding ban on boys, but not girls, wearing earrings to school justified by state interest in "discourag[ing] rebellion against local community standards of dress, under which earrings are considered female attire").

211. These cases date from a period when long hair on men was seen not only as impermissibly feminine but as dangerously radical-it was associated with hippies and the antiwar movement as much as with women. See, e.g., Bishop v. Colaw, 450 F.2d 1069 (8th Cir. 1971).

212. See, e.g., Martha Chamallas, Exploring the "Entire Spectrum" of Disparate Treatment Under Title VII: Rules Governing Predominantly Female Jobs, 1984 U. ILL. L. REV. 1, 10. While the circuit courts examining hair-length regulations in the employment context were unanimous in upholding them, some, but not all, challenges to sex-specific public school grooming codes were successful. The emphasis in these cases, however, is rarely on the sex discriminatory aspect of the codes, but rather on the students' liberty interest in their appearance. But see, e.g., Crews v. Cloncs, 432 F.2d 1259, 1266 (7th Cir. 1970) (finding denial of equal protection where "although girls engage in substantially the same activities in gym and biology classes, only boys have been required to cut their hair" short). See generally Mary Whisner, Note, Gender-Specific Clothing Regulation: A Study in Patriarchy, 5 HARV. WOMEN's L.J. 73 (1982) (noting role of clothing regulation in perpetuation of patriarchy). 
most at issue in disparate grooming standards for males and females:

If this interpretation of the Act is expanded to its logical extent, employers would be powerless to prevent extremes in dress and behavior totally unacceptable according to prevailing standards and customs recognized by society. For example, if it be mandated that men must be allowed to wear shoulder length hair . . . because the employer allows women to wear hair that length, then it must logically follow that men, if they choose, could not be prevented by the employer from wearing dresses to work if the employer permitted women to wear dresses. . . . Continuing the logical development of plaintiff's proposition, it would not be at all illogical to include lipstick, eyeshadow, earrings, and other items of typical female attire among the items which an employer would be powerless to restrict to female attire and bedeckment. It would be patently ridiculous to presume that Congress ever intended such result ....

- .

... An employer should be able to decline employment to a female applicant who shaves her head as clean as a billiard ball while not declining to hire a male applicant similarly groomed. A woman so groomed might well be an object of curiosity and derision, and, as such, counterproductive to the goals of the employer. Similarly, the employer should be allowed to refuse employment to a male with locks and tresses falling to his shoulders ....213

To the extent we live in an age whose cultural icons include Fabio and Sinead O'Connor, the cultural differences the court relies on may no longer apply. Moreover, an employer who sets unisex standards, now also culturally acceptable, can avoid extremes of cross-dressing without setting sex-specific clothing standards. ${ }^{214}$ And, although dresses on men still are "a greater

213. Willingham, 352 F. Supp. at 1020-21.

214. Indeed, one concem a proponent of individual liberty might have about the success of an argument that sex-specific grooming standards violate Title VII is that an employer might well respond with a conventionally androgynous grooming code. If an employer could not prevent men from appearing in dresses, jewelry, long hair, and makeup if it allowed women to do so, the employer might prefer a complete ban on feminine attire to a policy allowing greater diversity in the appearance of its work force. If all employees were forced by regulation into the sort of work attire deemed appropriate for men, the workplace would be a much more drab place, and women, although freed from the oft-commented-on difficulty of finding acceptable workplace attire in the absence of anything like the male uniform, would also lose some of their oft-commented-on power of self-expression through clothing choices. See, e.g., Bartiett, supra note 39, at 2581 (citing work of Mary Joe Frug and Elizabeth Wilson). Note, though, that many blue-collar workplaces already impose a masculine uniform on employees. See Killebrew v. Local Union 1683 of AFSCME, 651 F. Supp. 95 (W.D. Ky. 1986) (requiring female employee to wear pants notwithstanding her religious objections to wearing masculine clothing). For an argument that unisex clothing, even if conventionally androgynous, promotes equality between the sexes, see Rappaport v. Katz, 380 F. Supp. 808, 809 (S.D.N.Y. 1974) (considering challenge to requirement that brides at New York City Hall weddings wear "a dress or skirt and blouse-no slacks" by bride who claimed that dressing in pants "protects [her] from much of the sex-role stereotyping to which women continue to be subjected both professionally and socially" and groom who claimed that "[b]ecause marriage has traditionally been an unequal yoke, it is essential to me that my marriage ceremony emphasize the equality of the partnership. For this reason, our dress at this ceremony must be virtually identical"). 
departure from the norm than is long hair,"215 the Boeing Company's list of acceptable "unisex clothing" for its employees now includes "nylon stockings, earrings, lipstick, foundation, and clear nail polish."216 Unquestionably, however, the culture still excludes many stereotypically feminine styles and articles of clothing from the range of what is acceptable in men. ${ }^{217}$ Indeed, while acceptable clothing and appearance may in some respects have grown more androgynous since the $1970 \mathrm{~s}$, this is, as discussed above, almost entirely because women have been allowed to adopt styles previously reserved for men. Indeed, although a wider range of men may be wearing earrings today than in the $1970 \mathrm{~s}$, in most other respects men may be less free to move their attire toward the conventionally feminine than they were in the days of pastel leisure suits, long male hair, love beads, and flower power. One piece of evidence of the continuing hostility of both the law and cultural norms to men's adoption of conventionally female attire may be the text of the Americans with Disabilities Act, which explicitly excludes from the protection of the Act virtually every conceivable form of a man in a dress-whether transvestite, transsexual, suffering from gender-identity disorder, or homosexual. ${ }^{218} \mathrm{~A}$ second is the continuing enforcement of sex-

215. Willingham, 352 F. Supp. at 1020 .

216. See Doe v. Boeing Co., 846 P.2d 531, 533 (Wash. 1993). For an example of greater accommodation of males who wish to wear conventionally female attire, see Leiby, supra note 166, at C1. Leiby describes how a transvestite male negotiated an exception to the D.C. school dress code to graduate from junior high school in "a woman's blouse, bell-bottoms and flats, not to mention a $\$ 120$ African Twist hairdo ... . [He] didn't wear a suit and tie, but neither did he dress as femininely as he wished. (He would have worn a linen pantsuit, he says.)" Id. at C1, C10. But note that even Slater was close to what Boeing's dress code would define as the unisex look-he was not trying to wear a dress.

217. Boeing's list of clothing unacceptable when wom by male employees, including preoperative male-to-female transsexuals, encompassed "obviously feminine clothing such as dresses, skirts, or frilly blouses" and, of course, the pink pearl necklace for which it fred Doe. Doe, 846 P.2d at 534 .

218. The Americans with Disabilities Act provides that, "Homosexuality and bisexuality are not impairments and as such are not disabilities under this chapter.... [T]he term 'disability' shall not include-(1) transvestism, transsexualism, pedophilia, exhibitionism, voyeurism, gender identity disorders not resulting from physical impaiments, or other sexual behavior disorders . . ." 42 U.S.C. $\$ 12211$ (a)-(b) (Supp. III 1991). See also the (wholly redundant?) § 12208 (specifying that "the term 'disabled' or 'disability' shall not apply to an individual solely because that individual is a transvestite"). Of course, it is hard to believe that Congress so scrupulously excluded all forms of men in dresses from the protections of the ADA simply because it believed them already completely protected by Title VII under the sexstereotyping analysis of Hopkins. By including homosexuals in my list, I of course do not mean to suggest that gay men habitually wear dresses, but merely to point out that the very short list of excluded conditions focuses extremely heavily on conditions associated with the transgression of conventional sex/gender categories. Others, however, are more willing to conflate female attire as well as effeminacy with homosexuality in males. See, e.g., Gay Inmates of Shelby County Jail v. Barksdale, No. 84-5666, 1987 U.S. App. LEXIS 6932 (6th Cir. June 1, 1987). In Barksdale, the court noted:

[T] he procedure in the past has been for the intake officer to make a purely subjective judgment whether the incoming arrestee is homosexual. Sometimes this judgment has been based on fairly probative evidence, as when a male arrestee arrives at the jail dressed as a female . . . O Other times the judgment is based upon less probative evidence, as when the intake officer's impression is that the arrestee appears weak, small or effeminate ....

Id. at *2-3; cf. Engler v. Rowland, No. C-90-3476-VRW, 1991 U.S. Dist. LEXIS 6619, at *1 (N.D. Cal. Apr. 15, 1991) (gay inmate alleging that prison psychiatrist told him that "because he does not act or look effeminate," he must be housed with heterosexual population). 
specific grooming codes against preoperative transsexuals; ${ }^{219}$ in the most notable of these recent cases, the Washington Supreme Court upheld the firing of a preoperative transsexual Boeing engineer for wearing a pink pearl necklace to work..$^{220}$ Another is that a number of post-Hopkins cases, without specifically discussing Hopkins or its implications, have upheld sexspecific grooming codes against claims by male plaintiffs who did not claim to be transgendered or transsexual but who nevertheless wished to engage in feminine behavior such as the wearing of jewelry. ${ }^{221}$

What does the continuing viability of sex-specific clothing regulations in the lower courts tell us about the limits of Hopkins? ${ }^{222}$ The recent apparel

219. See, e.g., Dobre v. AMTRAK, 850 F. Supp. 284, 286 (E.D. Pa. 1993) (dismissing sex discrimination claim by preoperative transsexual who claimed, inter alia, that "she was told that a doctor's note was required in order to dress as a female ... [and] she was required to dress as a male"); Star v. Gramley, 815 F. Supp. 276 (C.D. Ill. 1993) (rejecting claim by preoperative transsexual prison inmate for accommodation of cross-dressing). In Star, the court held:

The plaintiff's discrimination claim likewise fails. The plaintiff reasons that if women are allowed to wear pants, then he should be allowed to wear a dress. ... [The distinction is, however,] reasonably related to legitimate penological interests. ... .

First, the plaintiff is treated no differently from any other similarly situated (i.e., male) inmate. In any case, the differential treatment between men and women cannot sensibly be compared. Wearing pants is now generally accepted for women; whether it is fair or not, society frowns on men wearing dresses. A female inmate will not be victimized for wearing pants, but a male inmate wearing a dress faces ridicule or, worse, physical assault.

Id. at 278-79.

220. See Doe, 846 P.2d at 533-34, 538. Because the case did not raise a claim of sex discrimination, but only one of failure to accommodate Doe's gender dysphoria as required by a Washington state law prohibiting discrimination against the handicapped, the court did not consider the implications of Hopkins for Doe's claim.

221. See, e.g., Rathert v. Village of Peotone, 903 F.2d 510, 516 (7th Cir. 1990) (rejecting $\$ 1983$ challenge by male police officers disciplined for wearing ear studs while off duty because reprimand was rationally related to preventing loss of respect for police); Bedker v. Domino's Pizza, 62 Fair Empl. Prac. Cas. (BNA) 1848, 1850 (Mich. Ct. App. 1992) (upholding disparate hair-length standards, relying on Willingham and other 1970s cases to state that "for the most part ... Title VII protection does not encompass those characteristics not inherently immutable ... and that have no significant effect upon the employment opportunities afforded one sex in favor of the other"); Lockhart v. Louisiana-Pacific Corp., 53 Fair Empl. Prac. Cas. (BNA) 1412, 1413 (Or. Ct. App. 1990) (relying on Willingham and other 1970s haircut cases to uphold employer's rule allowing females, but not males, to wear "facial jewelry while on the job"); cf. Williamson v. A.G. Edwards \& Sons, Inc., 876 F.2d 69, 70 (8th Cir. 1989) (rejecting race discrimination claim by black homosexual because "[a]lthough he alleged he was reprimanded for wearing makeup at work while two white alleged homosexuals were only reprimanded for wearing jewelry, there is no indication in the record that the other two men wore any makeup"). One way of describing the difference the Williamson court saw between Williamson's conduct and that of the white gay men who were not fired is in gendered terms. Although jewelry such as earrings and gold chains for men has a macho history among certain cultural subgroups, and is gradually becoming generally acceptable attire for men, today makeup is seen as exclusively feminine, and thus prohibitable. For analysis of Williamson centered on the intersection of the plaintiff's race, sex, and sexual orientation, see Mary Eaton, Homosexual Unmodified: Speculations of Law's Discourse, Race, and the Construction of Sexual Identity 14-18 (presented at Columbia Law School Feminism and Legal Theory Workshop on Re-Exploring the Questions of Essentialism, Nov. 1994) (unpublished manuscript, on file with author). "Williamson's race disappears as a concern of any legal consequence, then, because he was much too queer to be black or, to put matters somewhat differently, because the rouge was thick enough to conceal the noir." Id. at 17.

222. Of course, since none of the plaintiffs in these cases explicitly relied on Hopkins, the question cannot be asked in the most direct and narrow sense. If properly presented and argued, an objection to sexspecific grooming codes that relied on Hopkins might succeed. For the present, however, my question is designed to inquire in a broader way about the extent to which recent legal developments reflect a willingness to apply the lessons of Hopkins in a sex-neutral, gender-neutral way or, alternatively, are 
cases cited here allow an employer to require a man to "dress more [masculinely], [remove] makeup, have his hair [cut], and wear [no] jewelry." Has any post-Hopkins case required feminine attire for women? ${ }^{223}$ The trend suggests not-California, for example, recently passed legislation making it a violation of state sex discrimination laws for an employer to prohibit female employees from wearing pants. ${ }^{24}$ The New York Bar held it was not a violation of professional ethics for female attorneys to wear pants to court. $^{225}$ Indeed, one court has upheld a requirement that women, like men, wear "trousers, overalls or a jumpsuit" and not skirts or dresses on the job against a religious accommodation claim by a woman who "came to the conclusion that a verse found in Deuteronomy mandated her not wearing masculine clothing." 226 And another court, in striking down an ordinance

indicative of the tendency I noted at the beginning of the Article to approve of divergence from gender role norms or sex stereotypes in one direction only-toward the masculine.

223. Cf. Graham v. Texasgulf, Inc., 52 Fair Empl. Prac. Cas. (BNA) 799, 801 (D. Conn. 1987) (dismissing discharge claims of female plaintiff although noting in passing that plaintiff was "informed that she was to wear skirts to work rather than slacks, and she was asked to use her marital sumame").

224. CAL. Gov'T CODE $§ 12947.5$ (a) (Deering 1995) ("It shall be an unlawful employment practice for an employer to refuse to permit an employee to wear pants on account of the sex of the employee."). Compare employment discrimination regulations previously adopted by the California Fair Employment and Housing Commission, CAL. CODE REGS. tit. 2, div. 4, § 7291.1(f)(2) (1995) ("It is lawful for an employer . . to impose upon an appplicant or employee physical appearance, grooming or dress standards. However, if such a standard discriminates on the basis of sex and if it also significantly burdens the individual in his or her employment, it is unlawful."). Cf. Barbetta v. Chemlawn Servs. Corp., 669 F. Supp. 569, 573 (W.D.N.Y. 1987) (finding "requirement that female employees wear skirts or dresses on certain occasions because a visiting supervisor liked to look at legs" evidence of hostile environment); Fewer Promotions and Unequal Employment Terms for Females is Sex Discrimination, EEOC Decisions 1973 (CCH) I 6156, at 4263, 4264 (1970) (finding employer's provision of "only men's bicycles for" employee travel within employment complex discriminated against female employees, especially when the employer "forbade female employees to wear slacks, but placed no restrictions upon male attire"). But see Lanigan v. Bartlett \& Co. Grain, 466 F. Supp. 1388, 1390-91 (W.D. Mo. 1979) (upholding discharge of secretary for wearing pantsuit notwithstanding claim that "not allowing women to wear pants perpetuates the stereotype that men are more capable than women of making business decisions" and that "employer could offer no excuse whatsoever as to why his secretary could perform a job in a more efficient manner in a skirt ... and could only speculate as to whether or not a skirt could be considered more business-like"). The California statute is intriguing in its formulation. It stops well short of abolishing sex-specific dress codes, requiring only that women be permitted to choose one particular item once reserved for males. Is it the comfort/practicality or the masculinity/androgyny of pants that the statute seeks to guarantee women? Although the intent may be to allow women to wear professional attire indistinguishable from men's, the wording of the statute leaves some room to question whether an employer can require that the pants worn by female employees be of a feminine style or color so long as no obviously demeaning or overtly sexualized style is imposed. For, while skirts may be the ne plus ultra of effeminacy in men, they may no longer so clearly mark femininity in women. I would, for example, contend that a woman in flowered pants is today likely to be read as more feminine and less masculine than one in a drab, solid, knee-length, A-line skirt. Cf. Blowers v. Lawyers Coop. Publishing Co., 27 Empl. Prac. Dec. (CCH) 92,284 (W.D.N.Y. 1981) (finding no violation of Title VII where employer's dress code imposed more detailed and restrictive standards for dress on females than on males).

225. David Margolick, At the Bar, N.Y. Times, Jan. 1, 1972, at B16. But cf. Devine v. Lonschein, 621 F. Supp. 894,897 (S.D.N.Y. 1985) (rejecting sex discrimination claim by male attorney required to wear tie in court because "[a]t least until that dreadful day when unisex identity of dress and appearance arrives, judicial officers ... are entitled to some latitude in differentiating between male and female attomeys, within the context of decorous professional behavior and appearance"). Query what sex-specific behavior New York courts may still require from attorneys.

226. Killebrew v. Local Union 1683 of AFSCME, 651 F. Supp. 95, 96 (W.D. Ky. 1986). The biblical verse in question provides that "[a] woman shall not wear a man's apparel, nor shall a man put on a 
banning cross-dressing, explicitly noted the need to protect women in masculine attire. ${ }^{227}$ While "logic," as the Willingham court admits, would demand parallelism, the lesson may once again be that gender bending is permitted in one direction only-toward the masculine.

So it was that Judge Houck in the Citadel case ${ }^{228}$ would have allowed the school, over the objections of the plaintiff and the Justice Department, to shave Shannon Faulkner's head in the billiard-ball-like one-eighth-inch "knob cut" traditional for Citadel cadets because " "[s] he sought equal treatment . . . and we ordered that she receive equal treatment.",229 The Justice Department, however, in its brief opposing imposition of the knob cut, raised the specter of the man in a dress to argue for continued deference to cultural norms as a justification for separate male and female grooming standards:

We note that Hogan, involving admission of a male to the Mississippi University for Women's nursing program, did not require men to adopt the standard white dress which is the traditional nurse's uniform.

The opening of the traditional women's occupation of stewardess, now neutrally denominated "flight attendant", did not subject men to women's grooming standards, although there is no bona fide physiological reason that men could not conform to the existing haircut and make-up regulations which historically governed stewardesses. $^{230}$

The man in a dress remains the reductio ad absurdum for the Justice Department in 1994 that it was for the courts in the 1970s.

Let me again stress that the concern for the rights of men in dresses I

woman's garment; for whoever does such things is abhorrent to the LORD your God." Deuteronomy 22:5. As a small piece of additional evidence of the differential treatment given the imposition of masculine and feminine norms on female employees, compare Tamimi v. Howard Johnson Co., 807 F.2d 1550 (11th Cir. 1987) (upholding sex discrimination claim by pregnant woman who refused on religious grounds to comply with employer's demand that she wear makeup to work).

227. See City of Cincinnati v. Adams, 330 N.E.2d 463, 466 (Ohio, Hamilton County Mun. Ct. 1974) ("The ordinance] goes so far as to bring under suspect the woman who wears one of her husband's old shirts to paint lawn furniture.").

228. For further discussion of the Citadel and VMI cases as examples of the failure of legal analysis to disaggregate sex and gender, see infra Part VI.

229. Catherine S. Manegold, Judge Rules That the Citadel May Shave Woman's Head, N.Y. TIMES, Aug. 11, 1994, at A14 (quoting Judge Houck's oral statement referring to his July 22 ruling). Notwithstanding this ruling, the Citadel decided not to insist on shaving Faulkner's head, and she instead joined the corps of cadets retaining the above-the-collar hairstyle characteristic of women in the U.S. military.

230. Memorandum of the United States in Support of Motion for Reconsideration or Stay Pending Appeal at 6 n.1, Faulkner v. Jones, 858 F. Supp. 552 (D.S.C. 1994) (No. 93-0488). I do not mean to suggest that an argument from culturally coded dress norms is entirely without merit. Even if the intent of the knob cut is to humiliate the cadet, it may, indeed, be so much more humiliating in this society for a female to shave her head (as it would be for a male to wear a dress), that shaving Faulkner, though like treatment, would not be equal treatment. Compare the argument of male employees of the Jenny Craig fitness studios that it constituted sex discrimination to require them to wear the smock and pale blue scarf that make up the uniform for all employees, $90 \%$ of whom are female, see supra note 96. 
exhibit here stems not simply from a concern for the protection of their personal liberty, nor from a mere abstract commitment to promoting a sexblind approach to sex discrimination. ${ }^{231}$ Rather, I begin with the claim of numerous legal and cultural commentators that conventionally feminine apparel has often been used as a mark of female subordination. ${ }^{232}$ One solution often proposed by those who adhere to such a view is the elimination of such attire-the imposition of something like a unisex style derived in large part from conventionally masculine attire which, it must be conceded, generally outdoes conventionally feminine attire in comfort, practicality, and value for money, if not in variety or perhaps in aesthetic appeal.

My approach in this Article is a somewhat different one. Put quite tendentiously, my contention in pressing quite strongly the claim that sexspecific clothing regulations constitute disparate treatment of a sort prohibited by Title VII is that the world will not be safe for women in frilly pink dresses-they will not, for example, generally be as respected as either men or women in gray flannel suits ${ }^{233}$ - unless and until it is made safe for men in dresses as well. Rather than eliminate feminine styles, in clothing and elsewhere, I would prefer to enable them to be more generally valued. While I do not approve and do not mean to encourage the societal tendency to devalue most things limited to women and to value them only insofar as men feel free to engage in them, I do note it, as have many scholars and commentators. In light of this tendency, it seems that one of the most effective ways to improve the value of something coded feminine-whether something as serious as being the primary caregiver for one's child or as seemingly trivial and frivolous as wearing a dress, makeup, or jewelry-is to make it accessible to and acceptable in men. This certainly has, as noted above, been the approach of those seeking to integrate pink-collar ghettos in the workplace, and it is part of my strategy here. Unlike the strategies of many of those promoting the integration of pink-collar ghettos, however, the disparate treatment half of the approach outlined here would only protect, not

231. Let alone from any personal aesthetic preference for dresses on men. But cf. Cathy Horyn, Karl Lagerfeld's Frisky Business, WASH. POST, Oct. 18, 1994, at B1, B6 (describing fashion show in which designer displayed "floral printed dresses (worn, in a tweaky bit of gender bending, by some frisky male models with matching kerchiefs)").

232. See HOLLANDER, supra note 54, at 39; see also DUNCAN KENNEDY, SEXY DRESSING ETC. 188 (1993). Case law has occasionally recognized this subordinating effect. See, e.g., EEOC v. Sage Realty Corp., 507 F. Supp. 599, 608-11 (S.D.N.Y. 1981) (upholding sex discrimination claim by female employee required to wear revealing, sexy costume for job as building lobby attendant); Michigan Dep't of Civil Rights ex rel. Cornell v. Edward W. Sparrow Hosp. Ass'n, 377 N.W.2d 755, 764, 757 (Mich. 1985) (upholding lower court decision striking down sex-specific dress codes for hospital technicians because codes "were intentionally designed to reinforce sexual stereotypes: men were dressed to look like doctors, and women were dressed to look like nurses" and because requiring "female lab technicians to wear a kind of uniform that implied that they were of lower status than the male lab technicians increased the psychological burden on the females").

233. See Sandra M. Forsythe, Effect of Applicant's Clothing on Interviewer's Decision to Hire, $20 \mathrm{~J}$. APPLIED SOC. PSYCHOL. 1579 (1990) (suggesting that female applicants in more masculine clothing are perceived as possessing more desirable management traits and are more likely to be hired). 
necessarily encourage, men who engage in behavior coded feminine. At the very least, I would contend, the law should place no obstacle, such as, for example, that posed by ordinances criminalizing cross-dressing, ${ }^{234}$ in the way of men who choose to manifest such stereotypically feminine behavior.

The other portion of the approach to gender discrimination outlined here-forcing employers to re-evaluate their use of characteristics coded masculine and feminine as job requirements in the workplace by making gendered characteristics the basis for a disparate impact claim-would ideally result, not so much in the integration of men into pink-collar ghettoes, but in the integration of feminine qualities and of those exhibiting them into the sort of high-status, high-paying jobs previously coded masculine. I shall now turn to this portion of the analysis by taking up the treatment under antidiscrimination law, not of the effeminate man, but of another of Ann Hopkins's potential alter egos, the feminine woman.

\section{Feminine Women}

If the protection afforded effeminate men by Title VII remains an open question, that afforded feminine women is also uncertain. For the former, we have too little data; for the latter, numerous and subtle pieces of evidence, pointing in several directions. In the case most directly parallel to Hopkins, decided two years earlier, the Seventh Circuit upheld the dismissal of a woman, Marsha Wislocki-Goin, exclusively for failure to dress more masculinely, act more masculinely, remove her makeup, and wear her hair up. ${ }^{235}$ The job from which Goin was fired, teacher in a juvenile detention center, would not traditionally be gendered masculine. But the teacher's supervisor, a female judge, considered it important that all employees dress conservatively:

Although there [was] no written dress code, Judge Mears describe[d] her dress standards as the "Brooks Brothers look." ... Ms. Goin failed to conform to Judge Mears' appearance requirements at work by wearing excessive makeup and by wearing her hair down. . . .

234. Many criminal statutes prohibiting cross-dressing have given rise to litigation in the last 30 years. Some were struck down as invalid on their face because they were deemed impermissibly vague, especially in light of unisex and androgynous fashions that made it difficult to tell what was male and what was female attire. See, e.g., City of Columbus v. Rogers, 324 N.E.2d 563, 565 (Ohio 1975). Others were upheld, and still others were struck down only as applied to preoperative transsexuals, thus proving that transsexuals who believe they have to acquire vaginas in order to wear dresses may have a point at law. See, e.g., Doe v. McConn, 489 F. Supp. 76, 79-80 (S.D. Tex. 1980) (striking down ordinance making it illegal to appear in public "dressed with the designed intent to disguise [one's] true sex as that of the opposite sex" as applied to "individuals undergoing psychiatric therapy in preparation for sex-reassignment surgery"). While the holding in McConn is so limited, the reasoning supports a broader result. See Dunlap, supra note 142, at 1137.

235. Wislocki-Goin v. Mears, 831 F.2d 1374, 1376 (7th Cir. 1987). 
Ms. Goin's dress and grooming habits were not the only conduct of which Judge Mears disapproved. At a deposition hearing of a disturbed juvenile, Ms. Goin wept openly in front of the child. The chief referee, believing that Ms. Goin's conduct was unprofessional and inappropriate, reported the incident directly to Judge Mears. . . . Otherwise, Ms. Goin performed her teaching duties in a thoughtful, capable, and professional manner. ...

....

... In late January 1983 , Ms. Goin was notified that she was terminated for two acts of insubordination-wearing her hair down and wearing excessive makeup. ${ }^{236}$

Goin brought suit on both a disparate treatment and a disparate impact theory and lost on both. Her theory of disparate impact conceded that "the dress and appearance code was facially neutral," but argued that "it in fact fell more harshly upon women" simply because "no male was ever discharged because of appearance."237 The claim failed largely on evidence that not only the judge and the referee, but many of Goin's coworkers were women, and "Goin presented no evidence that Judge Mears' standards had worked a hardship on females."238 It is possible, although far from certain, that Goin's claim might have made more sense had it been phrased in terms of a disparate impact, not directly on women, but indirectly through discrimination against the display of feminine traits such as long hair, makeup, and tears and in favor of the masculine Brooks Brothers style. ${ }^{239}$

Some courts have not hesitated to see criticism of a woman for behaving in too feminine a way as evidence of sex discrimination. For example, the Ninth Circuit upheld an award in favor of a woman charging sex discrimination in her evaluations for the traditionally masculine job of police officer on evidence that, inter alia,

Ms. Fadhl was described by one officer as being "too much like a woman." Another officer stated in an evaluation form that, "After work she can become feminine again." A third officer described Ms. Fadhl as "very ladylike at all times, which in the future may cause

236. Id. at 1376-77 (citations omitted). The only other behavior of Goin's that drew Judge Mears's disapproval was her writing of a "Dear Santa" letter for a Christmas party. Id. at 1376.

237. Id. at 1378 . One, however, was reprimanded for wearing a sweater rather than a suit. Id. at 1380 n.5.

238. Id. at 1380; cf. Chamallas, supra note 136, at $111 \mathrm{n} .91$ (noting that even in "predominantly female contexts ... . pressures beyond the specific organization ... may prompt women decisionmakers to perpetuate male-focused norms").

239. The court did rule that Mears's conservative grooming standards met the business necessity requirement. Wislocki-Goin, 831 F.2d at 1380 . The court did not consider the stereotypical connection between a masculine and a conservative professional image, however. It would have been interesting to know more about the gendered appearance of the other female employees. Did they indeed all wear Brooks Brothers suits, short hair, and no makeup and resolutely refrain from weeping? Was Goin the only "feminine" woman on staff? 
problems," and he instructed Ms. Fadhl not to look "too much like a lady."240

The lower court in Fadhl made the gender discrimination issue explicit. It noted that, by explaining that his remark, "'[a]fter work she can become feminine again" signified that "after work, plaintiff could become a civilian again, that she could abandon the 'officer bearing' required to be a police officer," Fadhl's supervisor was indicating that "being 'feminine' is inconsistent with being a police officer, just as being a civilian is inconsistent with being a police officer, because neither females nor civilians can command the requisite officer bearing."241 Employers subjected some female sex discrimination plaintiffs to what might be called a double whammy, rather than a double bind-they criticized them both for manifesting and for failing to manifest stereotypically feminine behavior. ${ }^{242}$

In other cases, though, even explicit criticism for being "too feminine" is not viewed as evidence of sex discrimination, but at worst as a perhaps awkward formulation of a legitimate objection to performance on the job. For example, in a case challenging denial of tenure to a female academic, the court dismissed as evidence of sex discrimination a comment by a tenure reviewer that "Dr. Zahorik's problem in attracting graduate students was that she was too 'feminine' in that she was too 'unassuming, unaggressive, unassertive and not highly motivated for vigorous interpersonal competition." "243 In the court's view, "[t]he author, however, was discussing not her gender but rather the effect of her personality on graduate students

240. Fadhl v. City \& County of S.F., 741 F.2d 1163,1165 (9th Cir. 1984).

241. Fadhl v. Police Dep't, 553 F. Supp. 38, $42-43$ (N.D. Cal. 1982); see also Catlett v. Missouri Highway \& Transp. Comm'n, 589 F. Supp. 929, 938 (W.D. Mo. 1983) (finding sex discrimination where "interviewer disqualified female applicants who were "too feminine" as well as those perceived to be too short, too light, "not strong enough or built right for the job" of "maintenanceman," although some short, lightweight men were hired).

242. See, e.g., Rabidue v. Osceola Ref. Co., 805 F.2d 611, 624 (6th Cir. 1986) (Keith, J., dissenting) (asking "[h]ow plaintiff can be so abrasive and aggressive as to require firing but too timid to collect delinquent accounts"); Magnuson v. Peak Technical Servs., Inc., 808 F. Supp. 500, 506 (E.D. Va. 1992) (describing how plaintiff auto dealer was told both that she should not wear flat-heeled shoes because "her legs were very "sexy" and that she was "'too cute' for the position" and "dressed in an unprofessional manner"); Wiener v. Polaroid Corp., 790 F. Supp. 363, 366-67 (D. Mass. 1992) (recognizing prima facie case of sex discrimination based on evidence that plaintiff's supervisor "called her a 'little girl' and said that she needed to be controlled," "that defendants assailed her for being 'too strong,' "immature,' and 'controlling,' and accused her of engaging in 'little girl' behavior," and that her supervisor "warned plaintiff that she was too outspoken and assertive and that that would not play well at Polaroid"); Skelton v. Balzano, 424 F. Supp. 1231, 1234-35 (D.D.C. 1976) (describing how supervisor, who disliked "'pushy women," also faulted plaintiff for "bursting out in tears at meetings" and stating that "[p]laintiff was assertive and this annoyed [her supervisor], particularly because she often had tears down her face when pressing a point," although "tears were apparently due to a physiological condition rather than crying as it appeared to be").

243. Zahorik v. Cornell Univ., 729 F.2d 85, 89-90 (2d Cir. 1984). Incredibly, the appeals court upheld summary judgment for Cornell University, finding "the record is barren of any evidence that gender influenced the decisions." Id. at 94. 
seeking strong minded committee chairpersons."244 Again, note that being "feminine" is viewed as the negation of a number of character traits classified as masculine in the various sex-role inventories and viewed unhesitatingly by the court as legitimate job requirements: it is to be unaggressive, unassertive, etc. $^{245}$ This is more the norm-an unhesitating endorsement of masculine character traits as necessary for the job.

The social science literature amply bears out this prejudice. Studies have shown, for example, that "there may be two levels of sex stereotyping: one leading to bias against females and another leading to bias against individuals with feminine characteristics." 246 Many studies confirm this bias against the feminine with respect to high-status jobs conventionally coded masculine. According to some studies, it even applies with respect to low-status jobs conventionally coded feminine. ${ }^{247}$ Often noted are studies showing an almost perfect overlap between qualities attributed to the ideal man and the

244. Id.

245. The court here was operating under the simple bipolar model of gender represented in Figure 1. Cf. Menkel-Meadow, supra note 59:

[W]e may label the quality of caring a female quality, but note its presence in many men. Further, a man who exhibits many feminine qualities may be perceived as feminine, e.g. "He's too sensitive to be a good trial lawyer," or alternatively, an assertive woman may be met with remarks such as, "She's as sharp as any of the men on the team." Attributing behavior characteristics to a particular gender is problematic, because even as we observe such generalizations to be valid in many cases, we risk perpetuating the conventional stereotypes that prevent us from seeing the qualities as qualities without their gendered context.

The process is one that most feminists deplore because what is labeled female or feminine typically is treated as inferior, and is subordinated to what is labeled male or masculine. This is particularly true if the context in which they are found is one, such as the practice of law, which has itself traditionally been labeled male.

Id. at 41 (footnotes omitted). Menkel-Meadow seems to treat the feminine as female throughout the rest of the piece, however.

246. Thomas L. Ruble et al., Sex Stereotypes: Occupational Barriers for Women, 27 AM. BEHAV. SCIENTIST 339, 345 (1984).

247. See id.

In most ... studies, candidates were evaluated higher for sex-appropriate positions. That is, males were favored over females for masculine-typed jobs, and females were favored over males for feminine-typed jobs.

There are, however, exceptions to this general tendency. . . . [For example, Dipboye and Wiley's r]esults indicated that moderately aggressive candidates were favored over passive candidates for the position of supervisor, while the reverse was true for the position of editorial assistant. For both positions, the sex of the candidate did not affect the evaluations.

... [T]he Dipboye and Wiley findings can be interpreted as favoring masculine characteristics for a male-typed job and feminine characteristics for a female-typed job. If we expect men to display masculine characteristics to a greater extent than women, these trait-based stereotypes generally would operate to place males in the higher prestige position of supervisor and females in the supportive role of editorial assistant.

Additional ... studies found a bias favoring masculine characteristics regardless of the sex of the job candidate. Moreover, this masculine bias was observed even for female-typed roles. Thus there may be two levels of sex stereotyping: one leading to bias against females and another leading to bias against individuals with feminine characteristics.

Id. at 344-45 (citations omitted). Note that only discrimination against females has unequivocally been held to violate Title VII, although, of course, it is my claim that conventional disparate impact analysis offers some relief from across-the-board discrimination against those with feminine qualities. See infra Part $\mathrm{V}$ for further discussion. 
ideal manager and not only very little overlap, but often a negative correlation, between the qualities of a woman and a manager. Studies show the various forms of sex and gender stereotyping reinforcing each other to the systematic detriment of women-one stereotype leads evaluators simply to assume that managerial jobs require masculine traits, another simply to assume that female candidates lack these traits. ${ }^{248}$

A solution that re-evaluates jobs and the characteristics necessary to succeed in them has long been advocated by feminist theorists. Some simply wish to equalize the value of male and female traits. ${ }^{249}$ This is close to classical comparable worth approaches, which have, of course, been rejected by courts in this country, though they are mandated by the law of the European Union. ${ }^{250}$ Others, whose approach I believe holds a more realistic chance of implementation here, urge a case-by-case reexamination of the match between a job and traits useful in its performance. ${ }^{251}$ For example, focusing on the facts of the Sears case, which showed women underrepresented in commission sales jobs for which Sears selected applicants displaying various masculine traits, Lucinda Finley has suggested:

First, rather than blaming women and their nature for their underrepresentation in the high paying jobs, why not reexamine the jobs and their values? It may not be necessary for a salesperson to be an aggressive hustler ... to sell the commissioned items successfully. It may not be necessary to pit salespeople against each other; they could cooperate as a team .... Second, is the qualifications personality profile really geared to the needs of the job, or does it merely describe those who have been doing the job and the way they have been doing it? Just because a particular set of traits seems to produce sales, another approach is not necessarily doomed to failure. It may be useful to reexamine the designation of some items as commission items and others, usually associated with women, as noncommission, and thus less "important" and remunerative to sell. 252

248. See Deborah L. Freedman et al., Effects of Demographic, Experiential and Attitudinal Factors on Occupational Sex Stereotypes, 6 EMPLOYEE RESP. \& RTS. J. 115, 116 (1993).

249. See Littleton, supra note 63 , at 1335 . For example, "caring and self-reliance would be valued equally, and pleasing in its twisted form [involving satisfying superficial whims] would only be valued as much as the twisted form of self-reliance, that obliviousness to others that arises from their dependence on your sufferance." Id.

250. Compare AFSCME v. Washington, 770 F.2d 1401 (9th Cir. 1985) (rejecting theory of comparable worth) with Council Directive 75/117 of February 10, 1975 on Application of Laws Relating to Equal Pay for Men and Women, art. 1, 1975 O.J. (L 45/19) (mandating equal pay for work of comparable worth).

251. See, e.g., Kathryn Abrams, Gender in the Military: Androcentrism and Institutional Reform, LAW \& CONTEMP. PROBS., Autumn 1993, at 217, 229-30.

252. Lucinda M. Finley, Choice and Freedom: Elusive Issues in the Search for Gender Justice, 96 YALE L.J. 914, 939 (1987) (citations and footnote omitted). 
These suggestions are not simply ivory tower theorizing; they may have been implemented at Sears in an early era and were re-implemented during and after the case as part of an affirmative action plan. ${ }^{253}$ But, unfortunately, they were not considered as a principal part of the litigation. Rather, the courts in Sears seem to have taken more or less for granted not only women's essential lack of interest in commission sales, but Sears's assumptions as to both the commission sales jobs and the qualities necessary for success in them. By contrast, in the course of cases in which they held that jobs found to be appropriately gendered feminine could not on that account be per se closed to men, courts have for nearly a quarter century undertaken a specific factual inquiry into whether particular gendered qualities (as opposed to persons of the sex associated with those qualities) were necessary for job performance. With respect to jobs as diverse as flight attendant and police officer, the courts have closely examined employer claims that feminine traits were necessary but have usually found that they were but that males were

253. See infra text accompanying notes 288-89; see also Vicki Schultz, Women "Before" the Law: Judicial Stories About Women, Work, and Sex Segregation on the Job, in FEMINISTS THEORIZE THE PoLITICAL 297 (Judith Butler \& Joan W. Scott eds., 1992). As Schultz notes:

[T] hat Sears' characterization of the commission sales job varied dramatically from the way the job was defined in an earlier era shows that there is nothing necessary or inevitable about the way Sears characterized it. In the period from 1890 to 1940, when department store managers were eager to attract women to retail sales jobs in the newly expanding service sector, managers defined the essence of "good selling" in stereotypically feminine terms rather than the masculine ones emphasized by Sears.

Id. at 331 n.49 (citing SUSAN PORTER BENSON, COUNTER CUlTURES: SALESWOMEN, MaNAGERS AND CUSTOMERS IN AMERICAN DEPARTMENT STORES, 1890-1940, at 130-31 (1986)).

Furthermore, Benson has argued that:

Qualities which had for a century been encouraged in women-adeptness at manipulating people, sympathetic ways of responding to the needs of others, and familiarity with things domestic - fit nicely into the new view of selling. . . . Making the store more and more like a home, executives encouraged saleswomen to act more and more like hostesses, to treat their customers as guests. Empathy and responsiveness constituted the irreducible core of selling skill. ... .

Managers praised "womanly" personal characteristics, but their emphasis on interaction also resonated with the collective aspects of women's culture. ... [F]emale networks valued cooperation over competition, stressed the commonalities of female experience, and provided channels for the exchange of services and emotional support. As dimly as retail managers understood women's culture and its modes of functioning, in some unexamined way their definition of selling skills rewarded women for being women, gave exchange value to their culture.

BENSON, supra, at 130-31.

Much as I'd like to believe Schultz's interpretation, I'm as skeptical of it as I am of Schroeder's interpretation on the merits, see supra note 99 , because it seems to me that the "feminine" sales job remains feminine, but was not commission sales. Instead, the job deseribed by Benson remained at the time of the Sears suit what it had been earlier in the century-the comparatively low-paying job of selling items neither big-ticket nor masculine on salary rather than commission. The fact that this job continued to be performed primarily by women, at Sears and elsewhere, helps explain why at the time the Sears suit was brought, the majority of Sears employees were female-indeed, Sears was the second largest employer of women after the federal government-even though very few of those women had commission sales jobs. See Thomas Haskell \& Sanford Levinson, Academic Freedom and Expert Witnessing: Historians and the Sears Case, 66 TEX. L. REV. 1629, 1641 (1988). 
capable of exhibiting such traits. ${ }^{254}$ If courts can examine the necessity of feminine traits, they surely can engage in similar inquiry as to masculine traits. And, given the likelihood of proxy bias and other contaminating factors, it is not as clear that such an inquiry would as often lead to a validation of the gendered job requirements.

\section{INCORPORATING THE CONCEPT OF GENDER DISCRIMINATION INTO LEGAL DOCTRINE}

Although I have raised the possibility above, I do not propose adding gender to the prohibited forms of discrimination under Title VII and other antidiscrimination laws. This is in part because it seems better to work within existing categories whenever possible. ${ }^{255}$ More controversially, some of my reluctance to add gender can be traced to my willingness to make a number of what more radical sameness theorists might see as concessions. First, unlike theorists such as Susan Moller Okin ${ }^{256}$ and possibly Richard Wasserstrom, ${ }^{257}$ I do not propose as a normative goal the abolition of

254. See, e.g., Button v. Rockefeller, 351 N.Y.S.2d 488, 492 (Sup. Ct. 1973) (reasoning that men as well as women can show sensitivity and empathy to female witnesses and prisoners); Diaz v. Pan Am. World Airways, 442 F.2d 385 (5th Cir. 1971). Diaz was one of two major cases challenging the per se exclusion of men from positions as flight attendants. While Diaz focused on the advantages of feminine nurturing and soothing qualities in the fight cabin, see id. at 387, the other major case focused on the claim that female sex appeal, rather than feminine charm, was a bona fide occupational qualification (BFOQ) in a flight attendant. In that case, the BFOQ was struck down because the court found that "femininity, or more accurately female sex appeal" was not necessary to the employer's business of transporting passengers safely and quickly. Wilson v. Southwest Airlines Co., 517 F. Supp. 292, 293, 302 (N.D. Tex. 1981). While phrased in the language of the BFOQ, cases such as these provide some sense of what an examination of the business necessity of gendered traits might look like. In saying this, I don't mean to endorse the details of either the Diaz or the Wilson court's analysis. Both courts, in my view, failed to distinguish adequately between the employer's business (transporting people) and that of the employee flight attendant (making the flight pleasant). Taken at face value, the analysis of these courts suggests that it would be difficult to impose any requirements at all on an employee whose job functions were not at the core of an employer's business. If a restaurant is in the business of serving food, for example, could its management object to rudeness in a waiter? Or can a widget manufacturer object to brusqueness in a receptionist? After all, the food and the widgets, like the passengers of the plane, will continue to be delivered, however unpleasantly. But see Bartlett, supra note 39, at 2576-79 (arguing that forcing employer to prove that its primary business is marketing of sexual titillation before upholding hiring policies or dress codes that sexually subordinate women has salutary effect of marginalizing employer and preventing it from hiding behind more respectable business purpose).

255. For example, the Pregnancy Discrimination Act would not have been necessary had cases like Geduldig and Gilbert incorporated discrimination on grounds of pregnancy under existing sex discrimination law. See supra note 23.

256. See SUSAN MOLLER OKIN, JUSTICE, GENDER, AND THE FAMILY (1989) (applying Chodorow's theories to argue for abolition of gender in a world in which male and female parents share childrearing tasks equally).

257. See Richard Wasserstrom, Racism, Sexism and Preferential Treatment, 24 UCLA L. REv. 581 (1977). Wasserstrom contrasts the "assimilationist ideal" in which sex is as irrelevant as eye color and all sex-role differentiation is eradicated with an ideal of diversity or tolerance and concludes that perhaps "all role-differentiation in society is to some degree troublesome." Id. at 614 . Wasserstrom's ideal has been criticized for "rest[ing] on a vision of equality that says we can all be equal if we just strip away all our differences. Life in such a world would be boring, impoverished, and unenriching." Lucinda M. Finley, Transcending Equality Theory: A Way Out of the Maternity and the Workplace Debate, 86 COLUM. L. REV. 
gender, simply its disaggregation from $\operatorname{sex}^{258}$ Second, I do not claim that gender is irrelevant to all jobs-even in the ideal world, some jobs might still be predominantly gendered masculine and some feminine, although possibly not the same jobs as are gendered thus today. I therefore think that it would be unwise categorically to forbid employers from considering a complex of gendered characteristics ${ }^{259}$ in making employment decisions, since those characteristics may very well be necessary to job performance. As I shall discuss in more detail below, incorporating gender discrimination under a disparate impact analysis allows businesses to meet their needs for employees who exhibit certain gendered traits, but it forces a potentially salutary reexamination of the extent to which it is merely historical experience, prejudice, or stereotypical assumptions that led the employer to prefer one set of gendered traits over another. If, indeed, there is no business necessity for requiring gendered characteristics-if, for example, feminine managerial or policing styles can be as or more effective than masculine ones-it should in the long run help and not hurt employers to adjust their hiring accordingly. For, assuming the prior preference for masculine leadership styles is the result of something like proxy bias, ${ }^{260}$ workplace performance as well as sex equality may well be improved by a reexamination of the gender stereotyping of jobs.

My reluctance to urge that gender discrimination be categorically prohibited also stems from the fact that, unlike some difference theorists, I am not committed as either a descriptive or a normative matter to the preservation of the conventional gender categories. I would be neither particularly surprised nor particularly disappointed if masculinity and femininity as we today define them were to be amalgamated, to be diversified, or to wither away in future generations. I therefore worry about two sorts of potential gender essentialism-not merely the essentializing of women as feminine, but the essentializing of the feminine itself. I do not propose the inclusion of gender as a prohibited basis for discrimination in part because this might increase the risk of reifying current definitions of masculine and feminine, which I would prefer had more room to develop, even to disappear. ${ }^{261}$

\section{8,1140 (1986).}

258. I do not have as a normative goal the preservation of gender any more than its abolition, however.

259. Once again, by "gendered characteristics," I mean only those conventionally so categorized, not anything like an "eternal feminine." As I discuss below, I wish to leave open the possibility that the content of the categories "masculine" and "feminine" may change or that the categories themselves may cease to have much meaning in the culture.

260. See Menkel-Meadow, supra note 59, at 40 ("Since our knowledge of how lawyers behave... is based almost exclusively on male subjects of study, our understanding of what it means to be and act like a lawyer may be misleadingly based on a male norm."); supra note 85.

261. It may seem doubly paradoxical to suggest both that gender can be disaggregated from sex and that it may then wither away. After all, if gender is originally defined entirely in terms of sex, a 
How, then, do I suggest that the law (as opposed to feminist theory) deal with gender discrimination under Title VII and other laws that now prohibit discrimination on the basis of sex? How should discrimination against effeminate men and feminine women, as well as the other possible sex/gender combinations, be handled? ${ }^{262}$ First, the passage of laws outlawing discrimination on grounds of sexual orientation would help solve the problem of overdetermination of discrimination against effeminate men-it would close what Frank Valdes has termed the "sexual orientation loophole" to claims of sex discrimination. ${ }^{263}$ Second, as to the requirement that employees conform their gender to their sex merely for the sake of such

disaggregation, if conceivable at all, seems likely to involve reifying those bundles of characteristics associated with masculinity or femininity at the time they are split off from maleness or femaleness. There are, however, historical precedents for the sort of conceptual shift I am here imagining, and a brief discussion of two of them may help illuminate the point. The first analogous precedent is that of the categories "noble" and "base"; the second is that of the humors or temperaments. Both examples involve classification schemes once quite prevalent, but which have lost virtually all significance in our contemporary society. In each case, the categories were, like that of gender, originally seen to have a physiological base from which they were then conceptually disaggregated. Thus, those with noble blood were seen to possess a variety of desirable characteristics the base-born lacked, from good bone structure to good character to grace and virtuosity. But as early as the time of Chaucer, the qualities associated with nobility could be disaggregated from the bloodlines that were thought to give rise to them, and those possessing such qualities could be characterized as noble regardless of their actual class origin. " $[\mathrm{H}] \mathrm{e}$ is gentil [i.e., noble] that dooth gentil deedes," says Chaucer's Wife of Bath, although for centuries thereafter in literature apparently base-born people who behaved nobly usually turned out to have been switched at birth. See GeofFrey ChauCER, CANTERBURY TALes, in ChaUCER's POETRY 218, 227-28 (E.T. Donaldson ed., $2 \mathrm{~d}$ ed. 1975). Compare the efforts of some transsexuals to assert that, because they manifest feminine gender characteristics in a male body, they must have been assigned to the wrong sex.

Over time, the qualities associated with nobility not only took on a life of their own, far removed from their origins, but noble/base also ceased to be an important fault line in the categorization of human beings in this society. Today, all men are or can be gentlemen, and all women ladies. And, for example, although the word "villain" still has contemporary significance, it has lost all resonance of its etymological origin in "villein" or "base-born." As Richard Rorty suggests, perhaps the distinctions and androcentric value judgments today associated with sex and gender may some day be forgotten, "just as we have all forgotten about the discussion between base and noble ancestry." Richard Rorty, Feminism and Pragmatism, 30 MICH. Q. REV. 231, 248 (1991).

Pressing too closely the analogies between noble and base, on the one hand, and masculine and feminine, on the other, would not be in the interests of someone like myself who wants feminine qualities to be more highly valued than they have been, however. The more the masculine is seen to resemble the noble, the less space remains for the feminine, even (indeed especially) in a world in which masculinity, like nobility, is seen as open to all who choose it. For this reason, an analogy to the concept of the humors, which did not embody the stark normative contrast of good and bad, may be helpful. Temperaments such as the melancholic or choleric were originally seen as dictated by and associated with a specific physiology - "the words carried much weight that they have since lost: the choleric man, for example, was not only quick to anger but also yellow-faced, lean, hairy, proud, ambitious, revengeful, and shrewd." 6 THE NEW ENCYCLOPAEDIA BRITANNICA: MICROPAEDIA 145 (15th ed. 1994) (defining "humour"). Today, however, although to describe someone as choleric is not meaningless, we have not only ceased to view persons of choleric temperament as by nature hot and dry and filled with an excess of yellow bile, but we are also quite unlikely to use the humors as a basis for categorizing or evaluating people in the first place.

262. For a schematic outline, see supra Table 1.

263. Valdes, supra note 29, at 18; see also MINN. STAT. ANN. § 363.01(45) (West Supp. 1995) (defining sexual orientation, inter alia, as "having or being perceived as having a self-image or identity not traditionally associated with one's biological maleness or femaleness"); Richard C. Paddock, S.F. Targets Anti-Transgender Bias, L.A. TIMES, Dec. 26, 1993, at A3 (reporting new San Francisco ordinance outlawing discrimination on basis of "gender identity" and intended to protect transsexuals, cross-dressers, and hermaphrodites from discrimination in employment and housing). 
conformity - that women be feminine and men masculine - this is, as I have discussed, already outlawed by the plain language of Title VII as well as by the prohibitions on sex stereotyping outlined by the Supreme Court: It is impermissible disparate treatment. ${ }^{264}$ As to categorical discrimination on the basis of gendered characteristics - the requirement by an employer that, for example, all those in a certain job, regardless of sex, display stereotypically masculine traits-this, too, is open to challenge under existing doctrine. Discrimination against the feminine or in favor of the masculine, for example, can be viewed as having a disparate impact on women, who are disproportionately likely to be feminine and not masculine; it should be permitted only if job-related and justified by business necessity, and men discriminated against for displaying feminine characteristics should be allowed to raise ius tertii claims. ${ }^{265}$

Both the disparate treatment and the disparate impact prongs of my analysis of gender discrimination under existing law may seem at once quite straightforward and quite troublesome. As to the disparate treatment of gender benders, as I have acknowledged above, however doctrinally airtight the claim that Title VII protects men in dresses may be, ${ }^{266}$ the suggestion is culturally

264. Notwithstanding its gender component, such discrimination, because it makes distinctions on the basis of a person's sex, is "therefore, sex discrimination plain and simple." J.E.B. v. Alabama ex rel. T.B., 114 S. Ct. 1419, 1436 n.1 (Scalia, J., dissenting); see supra text accompanying note 15.

265. Authority is split on the extent to which males have standing to bring a claim for injuries to them resulting from discrimination by their employer against women. Compare Patee v. Pacific Northwest Bell Tel., 803 F.2d 476, 476 (9th Cir. 1986) (denying standing to males in predominantly female job classification who claimed "that they receive lower wages because [their employer] discriminates against women") with Allen v. American Home Foods, 644 F. Supp. 1553, 1557 (N.D. Ind. 1986) (granting standing to male employees in plant slated for closure who claimed that plant had discriminatorily been selected for elimination because of plant's comparative predominance of women). I agree with Morrison Torrey that the more expansive view of male standing to bring such claims is the better one. See N. Morrison Torrey, Indirect Discrimination Under Title VII: Expanding Male Standing to Sue for Injuries Received as a Result of Employer Discrimination Against Females, 64 WASH. L. REV. 365 (1989). Granting standing to males adversely affected by a practice having a disparate impact on women is consistent with the view, propounded by both the courts and the EEOC, that "Congress intended that the language in $\$ 706(b)$, referring to an 'aggrieved' person, be construed to define standing [under Title VII] as broadly as possible under Article III." EEOC TECHNICAL ASSISTANCE PROGRAM, EEOC Policy Guidance: Whether Testers Have Standing, in THEORIES OF DISCRIMINATION app. 4, at 4 (1995) (citing, inter alia, Stewart v. Hannon, 675 F.2d 846, 849 (7th Cir. 1982)); see also EEOC TECHNICAL ASSISTANCE PROGRAM, EEOC Policy Guidance on Employer Liability under Title VII for Sexual Favoritism, in SEX DISCRIMINATION \& F at 4 (1995). Note once again the career of Ruth Bader Ginsburg as an advocate against sex discrimination, discussed supra text accompanying notes 10-11. Moreover, courts in those cases denying men standing relied heavily on the fact that the male workers did not claim that they had been discriminated against because they were men. See, e.g., Patee, 803 F.2d at 477 . In the peculiar case of discrimination against an effeminate man this is unlikely to be the fact-any employer that discriminates categorically against the feminine is probably going to discriminate to an even greater extent against men displaying feminine characteristics. The male plaintiff may thus be able to combine a Hopkins-like claim of discrimination against his gender bending with a claim sounding in ius tertii; he may need the latter only to overcome the defense that his genderbending did not cause the adverse employment decision because the employer required masculine qualities to a sufficient, although lesser extent, from all employees regardless of sex.

266. Again, consider the plain language of the statute, the Supreme Court's longstanding and oft-repeated rejection of "the entire spectrum of sex-stereotyping," and the specific holding of Hopkins $v$. Price Waterhouse. See supra Subsection IV.A.1. 
quite radical. Ease of implementation on a doctrinal level is thus more than offset by difficulty of implementation on a cultural level. ${ }^{267}$ As to the disparate impact prong, women in dresses (that is, feminine women) are culturally a more comfortable and sympathetic class of plaintiffs than men in dresses. Moreover, it seems far from controversial under existing law to suggest that characteristics disproportionately possessed-or, perhaps more importantly, disproportionately perceived to be possessed-by one or the other sex, characteristics at the core of sex-role stereotyping and gender identity, should not also be the ones on the basis of which employment decisions are made unless those characteristics are necessary for the job. That disparate impact analysis should be applied to categorical discrimination on the basis of gendered traits ${ }^{268}$ is thus also at one level a straightforward, fairly uncontroversial claim. ${ }^{269}$

On another level, however, applying disparate impact analysis to categorical discrimination on the basis of gendered traits may be seen as placing a can of worms atop a slippery slope. ${ }^{270}$ The can of worms is disparate impact, ${ }^{271}$ the slippery slope gender, ${ }^{272}$ and, unfortunately, an

267. See generally Bartlett, supra note 39 (discussing judicial reliance on "community norms").

268. By categorical discrimination I mean here discrimination in favor of or against a particular gendered trait or set of traits regardless of the sex of the person manifesting the traits. Again, by way of example, consider an employer who likes Ann Hopkins just the way she is and wouldn't change a thing about her but won't promote her more feminine counterparts unless they go to assertiveness training class and wear man-tailored suits to work. To the extent such an employer neither encourages nor tolerates behavior conventionally gendered feminine in members of either sex, it is using masculinity or particular masculine traits as a facially neutral job requirement, but one that is likely to have an adverse impact on persons of the female sex. Requiring the gendered trait thus tends to act as a "built in headwind" for persons of a particular sex.

269. For similar suggestions, see MiChaEl J. ZimMer ET AL., CASES AND MATERIALS ON EMPLOYMENT DISCRIMINATION 507 (3d ed. 1994); Eichner, supra note 100, at 1401. Other authors have, it seems, skirted (no pun intended) around the edges of such a claim but have stopped well short of making it. Thus, for example, Mary F. Radford concludes that "[t]he dismantling of the perception that women, or people with 'female' qualities, cannot be effective managers and leaders is vital to the effort of building a society in which there exists a balance between that which is traditionally 'male' and that which is traditionally 'female."' Mary F. Radford, Sex Stereotyping and the Promotion of Women to Positions of Power, 41 HASTINGS L.J. 471, 535 (1990). Yet notwithstanding her wish to end the "universal cognitive dissonance between the concepts of 'female' and 'feminine' and those of 'effective manager' and 'able leaders," Radford insists that the "purposes of Title VII include the rooting out of entrenched discrimination caused by prevalent sex stereotyping, but not the granting of windfall judgments to plaintiffs who would not have succeeded even if they had been men." Id. at 534. Still others have argued that jobs should be restructured, but they have usually confined themselves to urging that "[w]hile not claiming this is a legal mandate ... in a Sears situation men and women should be liberated from the constrictions of gender roles." See ZMMMER ET AL., supra, at 272 (describing argument made by Finley); see also Abrams, supra note 251 , at 226.

270. I am grateful to Mary Becker for this evocative image.

271. As a voluminous case law and legislative and scholarly literature demonstrates, every stage of disparate impact litigation, from identifying its statutory basis to establishing a prima facie case to determining whether a defendant can establish business necessity, is fraught with difficulty and confusion. See George Rutherglen, Disparate Impact Under Title VII: An Objective Theory of Discrimination, 73 VA. L. REV. 1297, 1298-99 (1987). None of the difficulties would be alleviated and some would be intensified in the application of disparate impact analysis to discrimination on the basis of gendered characteristics.

272. The slope is slippery because, some would argue, both individual gendered traits and gender itself are fluid and boundaryless. Thus, everything and nothing might be open to challenge, and adjudicating 
article of this scope allows me neither to open the former nor to struggle against the latter. While it is clear that in suggesting that disparate impact analysis is appropriate for categorical discrimination on the basis of gendered traits, I necessarily take on all the myriad problems and inherent messiness now generally recognized to be endemic to all disparate impact doctrine, it should be equally clear that I cannot solve those generic problems here, and I do not propose even to start in this Article. Nor would it be feasible within the scope of this Article to discuss at anything like a useful level of depth the mechanics of bringing particular claims challenging the disparate impact of various gendered job requirements.

Notwithstanding its messiness, however, I remain convinced that analyzing discrimination on the basis of gendered traits as sex discrimination is necessary to achieve the goals of Title VII-for courts to fail to take on the difficult problems of disparate impact on feminine women has much the same dangers as would their declining to face the similarly difficult problem of the subtle disparate treatment of masculine women like Ann Hopkins. A refusal

questions of gender would ask too much of courts. Without denying or fully exploring the complications inherent in the process of such adjudication, I have three general responses. First, the danger exists already-it is inherent in disparate impact doctrine given that, as one opponent of an expansive disparate impact doctrine noted, virtually everything has a disparate impact on some group. See Lynch v. Freeman, 817 F.2d 380, 391 (6th Cir. 1987) (Boggs, J., dissenting). Yet notwithstanding infinite gradations of skin tone, courts have managed to handle cases of intra-racial color discrimination. See, e.g., Walker v. Secretary of the Treasury, 713 F. Supp. 403, 408 (N.D. Ga. 1989) (acknowledging difficulties inherent in "measuring skin color and determining whether the skin pigmentation of the parties is sufficiently different to form the basis of a lawsuit," but holding that light-skinned black person may have Title VII cause of action against dark-skinned black person for discrimination on basis of color (citation omitted)).

Moreover, if the body of social science data cited supra notes $246-48$, is any indication, gender does not at this time in this society present all that fluid or boundaryless a concept. Studies of the sort cited above indicate great agreement among those surveyed as to which qualities, for example, are perceived as feminine, which as masculine, and which as neither. They also indicate fairly unequivocally that at present women are disproportionately likely to manifest (or to be perceived as manifesting) feminine qualities and men masculine ones. See, e.g., JoHN E. WILliaMS \& DEBORAH L. BeSt, MEASURING SEx STEREOTYPES: A MULTINATION STUDY (rev. ed. 1990). Of course, both the definition of gendered characteristics and their distribution in a population or between populations may change over time, but no less is true of the high school diplomas at issue in Griggs v. Duke Power Co., 401 U.S. 424 (1971). Let me be clear, however, that this is not to minimize the considerable problems a prima facie case of disparate impact based on gendered characteristics will present.

But, finally, because of what has been the close link between sex and gender, of all forms of disparate impact of subjective employment criteria, those based on gendered characteristics most show "a lingering form of the problem Title VII was enacted to combat." Watson v. Fort Worth Bank \& Trust, 487 U.S. 977, 990 (1988). One of the most important reasons why "disparate impact analysis is in principle no less applicable to subjective employment criteria than to objective or standardized tests" is, as Justice O'Connor put it, "because the problem of subconscious stereotypes and prejudices would remain" even if disparate treatment doctrine could adequately police discriminatory intent. Id. Watson extended disparate impact analysis to the subjective promotion practices of a bank that had failed to promote a black woman. O'Connor pointed to a remark about the position of teller involving "'a lot of money . . . for blacks to have to count," id., and noted that "[s]uch remarks may not prove discriminatory intent, but they do show a lingering form of the problem that Title VII was enacted to combat." Id. Precisely these sorts of subconscious stereotypes are, I would argue, at work in the tendency to assume that characteristics gendered masculine, if no longer maleness itself, are required for so many comparatively high-status and high-paying jobs in this society. The strength of the "built-in headwind" is increased to the extent that the measurement of the required trait is subjective and the lenses of gender tend to distort an employer's or evaluator's perceptions that the trait is possessed by members of one or the other sex. 
to take on such claims would make the goal of Title VII something more like institutionalized hypocrisy than equality of the sexes. For, if all that the next generation of people making employment decisions learn from the Hopkins case is to avoid explicit advice like "act more femininely" in evaluating their female personnel, and do not learn to change the stereotyped attitudes and policies that made this good advice, the next Ann Hopkins will not be free of sex discrimination, she will just have a much more difficult time proving it. And, as the Supreme Court has recognized, if courts knock out objective standards on disparate impact analysis but preclude employees from challenging subjective ones, far from eliminating discrimination, the courts have rather expanded even further the scope for covert discrimination under the hypocritical face of neutral standards. ${ }^{273}$

For much of the remainder of this part, I will use the example of the conventionally masculine job of police officer to explore the disparate impact of gendered job requirements. Part of my goal will be to show, with reference to the history of litigation over sex discrimination by the police, how the sort of disparate impact litigation I endorse is the logical successor to two strands of cases-class actions challenging the disparate impact on women of objective hiring criteria such as height, weight, and physical fitness tests; and disparate treatment suits by individual women challenging the perception, rooted in stereotypes, that they were unsuited to police work. I shall also argue that, important though it may be to demonstrate how a plaintiff can successfully bring suit alleging the disparate impact of requiring or prohibiting certain gendered traits, plaintiffs' lawyers should not be the only, or indeed the primary target, of the arguments put forward here. Another important objective should be persuading personnel managers or others who make employment decisions that a reexamination of the ways in which gendered characteristics are used in selecting, training, and evaluating employees is in the employer's own interests on every level.

In suggesting that voluntary action by employers may be a more fruitful avenue to a remedy than litigation by aggrieved plaintiffs, I have in mind the precedent of responses to sexual harassment. ${ }^{274}$ Sexual harassment seems to have moved very rapidly from something not seen as a legal problem to something much more than a legal problem. ${ }^{275}$ The early proponents of a

273. See Watson, 487 U.S. at 990.

274. For a detailed and thoughtful discussion of the advantages of approaches other than litigation, such as conciliation and especially voluntary employer compliance, in remedying sexual harassment, see Kathryn Abrams, Gender Discrimination and the Transformation of Workplace Norms, 42 VAND. L. REV. 1183, 1215-20 (1989).

275. A comprehensive and up-to-date social and legal history of the treatment of sexual harassment has, to the best of my knowledge, yet to be written, but it is clear that such a history would be grossly underinclusive if it focused exclusively on reported cases litigated through to a verdict for the plaintiff. For the early history of sexual harassment doctrine by one of those responsible for its development, see generally CATHARINE A. MACKINNON, SEXUAL HARASSMENT OF WORKING WOMEN (1979). 
Title VII remedy for sexual harassment were met by objections similar to those one might raise to the disparate impact prong of my proposal. They were told that the practice was so pervasive and of such long standing, the difficulty of drawing a line between the permissible and the impermissible (indeed at times between the desirable and the impermissible) so insurmountable, the problems of proof so complex, the issue so far from the core prohibitions of Title VII, that nothing could or should be done by the courts. ${ }^{276}$ Although until fairly recently, sexual harassment claims had a hard time getting into court, today employers are trying to keep them out of court (and out of the papers) by taking preemptive steps. ${ }^{277}$ And, while widely publicized plaintiffs' verdicts helped change employers' attitudes, the Hill-Thomas hearings, a watershed event in changing public attitudes toward sexual harassment, involved a woman who not only did not go to court, but who also did not "win" against her employer. ${ }^{278}$ The principle that sexual harassment is illegal sex discrimination is important to current attitudes, but these attitudes are not that closely informed by the boundaries of the law. With gender discrimination, as I believe has begun to be the case with sexual harassment, once a norm against the practice has started to develop, voluntary enforcement may well go beyond what the practicalities of enforcement through litigation may hope to achieve, although perhaps not beyond what the

276. See, e.g., CATHARINE A. MACKINNON, Sexual Harassment: Its First Decade in Court, in FEMINISM UNMODIFIED, supra note 85, at 103, 103.

277. Thus, even though a state agency exonerated one of Illinois Governor Edgar's associates of sexual harassment charges, "[t]he stigma [wa]s still there" and the Governor issued a new and tougher executive order against harassment. Edgar Releases New Sexual Harassment Policy, UPI, Dec. 18, 1992, available in LEXIS, Nexis Library, UPI File. Among the many corporations enforcing strong policies on sexual harassment with strict penalties are AT\&T and DuPont. See Stephanie Strom, Harassment Cases Can Go Unnoticed, N.Y. TIMES, Oct. 20,1991, at A1, A22. And many other companies are either giving employees special training in avoiding sexual harassment or bringing in consultants to deal with the problem. One author suggests that "companies should focus on prevention and handle complaints quickly, quietly, and without retribution" because in court "“[b]oth sides lose' [due to] tarred reputations, sinking morale, and other fallout." Michele Galen et al., Sexual Harassment: Out of the Shadows, Bus. WK., Oct. 28, 1991, at 30, 31 (quoting Freada Klein).

278. Another such event, the Tailhook scandal, led to preemptive action by the employer well before it led to a plaintiff's verdict. In the wake of Tailhook, "Naval Academy midshipmen tried role-playing and viewed videos depicting sexual harassment during a weekend seminar designed to try to rid the academy of attitudes that led to the Tailhook scandal," and the Naval Academy's superintendent announced a policy of "[z]ero tolerance of sexual harassment." Naval Academy Teaches Policy on Harassment, WASH. TIMES, Aug. 24, 1992, at B2. The Navy tried to capture what is and isn't impermissible sexual harassment under a traffic light scheme-the red zone defines clearly impermissible conduct, green clearly permissible; in the yellow zone, sailors are advised to proceed with caution. See Maureen Dowd, Navy Defines Sexual Harassment with the Colors of Traffic Lights, N.Y. TiMES, June 19, 1993, at A1. Even more effective was the Army's response, according to the U.S. Senate, which recently mandated that all service branches follow the Army's lead. Army's Sexual-Harassment Policy Backed, DALLAS MORNING NEws, July 2, 1994, at 8A. The Army included "situational vignettes" about proper behavior and also revised its complaint procedure to provide both formal and informal avenues for redress. Id. I do not mean to suggest by this or other discussions of preemptive employer responses to sexual harassment that they have thus far been effective at stopping the problem or that all employers and their supervisory personnel are sufficiently alive to its seriousness. 
letter of the law would require. ${ }^{279}$ What makes nonlitigious voluntary enforcement even more attractive for gender discrimination than for sexual harassment is that remedying the former seems more of a win-win situation-it is harder to see the countervailing value or to identify a loser. ${ }^{280}$

Although I am aware that a credible threat of litigation is often a prime motivating force for a change in employer policies, I am afraid that one of the many reasons for focusing on voluntary action rather than litigation is that, if the cases cited herein are any indication, even very strong claims of categorical gender discrimination may face a (to my mind unjustifiably) difficult time in the courts. ${ }^{281}$ Consider once again, for example, that Zahorik, the faculty member who was described by one of her colleagues as "too 'feminine' in that she was too 'unassuming, unaggressive, unassertive and not highly motivated for vigorous interpersonal competition," lost on summary judgment because the court found "the record is barren of any evidence that gender influenced the decisions." $282 \mathrm{Had}$ she lost after trial on the merits, there might have been more reason to hope that adding a disparate impact claim to her disparate treatment claim would have helped the court to see that precisely Zahorik's gender, and not some gender-neutral aspect of "her personality," was at issue in her case, just as it was in Hopkins's. But a court that finds no evidence whatsoever of sex discrimination in an evaluation of a plaintiff as "too feminine" for the job is unlikely to be moved to rule in her favor if a disparate impact claim is added to one for disparate treatment. Or consider that, while perhaps not artfully pleaded, Wislocki-Goin's disparate impact claim also failed, notwithstanding that she was fired from a conventionally feminine job, which she was concededly performing well in all other respects, simply for manifesting fairly trivial conventionally feminine behavior, to wit long hair, makeup, and tears. ${ }^{283}$ If

279. Thus, whether categorical discrimination on the basis of gendered characteristics actually has an impermissible disparate impact on the sexes, and whether it can be proven to do so in any given case, are not the same question. For both sexual harassment and gender discrimination, the realities of litigation may mean that some otherwise actionable harms, although not trivial, may be too costly or too complicated to remedy in court.

280. By contrast, with sexual harassment, a zealous employer may not be avoiding litigation so much as selecting its plaintiff. Voluntary enforcement of strict sexual harassment standards against an employee may lead that employee, rather than the person he allegedly harassed, to sue the employer. And against the zealous enforcement of norms against sexual harassment must be weighed this enforcement's potential chilling effect, not only on free speech, but also on interactions between people in the workplace. See, e.g., Silva v. University of N.H., No. 93-533-SD, 1994 U.S. Dist. LEXIS 13281, at *52-68 (D.N.H. Sept. 15, 1994) (enjoining university, on contract and First Amendment grounds, from suspending a professor for what it saw as inappropriate, sexually charged remarks in class).

281. I should note that in the early days of sexual harassment litigation, it was similarly difficult to find a receptive court. And, of course, often the credible threat of an expensive lawsuit, even one that may at the end of the day result in judgment for the defendant, is enough.

282. Zahorik v. Comell Univ., 729 F.2d 85, 89-90, 94 (2d Cir. 1983); see supra text accompanying notes $243-44$.

283. See supra text accompanying notes $235-39$. 
a court can find the "Brooks Brothers look" a business necessity even in the conventionally feminine job of teaching, few allegedly too-feminine disparate impact plaintiffs may have a chance. ${ }^{284}$

Interestingly, of all the cases discussed above, the one in which the addition of a disparate impact claim based on gender might have helped the plaintiff most is the Sears case. Arguably, a well-pleaded ${ }^{285}$ and welllitigated disparate impact claim could have used not only the EEOC's affirmative statistical case, but also much of Sears's own evidence and expert testimony as support. ${ }^{286}$ And there is reason to believe that Sears would have had trouble showing business necessity for the masculine personality traits it required of its commission sales force: Evidence introduced in the case indicated that Sears's own "in-house study actually linked higher 'vigor' scores with poorer salesmanship." ${ }^{287}$ Despite its litigation victory, Sears in recent years seems to have moved voluntarily from the masculine toward the

284. An additional case I have not previously discussed explicitly raised a claim of discrimination on the basis of employer preference for stereotypically gendered traits, but failed, according to the court, to present the claim in a sufficiently focused way or to provide the evidence necessary even to make a prima facie case. The plaintiff in that case alleged "a menu of acts ranging from general sexual bias to career assessments." Torre v. Federated Mut. Ins. Co., 854 F. Supp. 790, 810 (D. Kan. 1994). As to the former, she alleged:

a litany of acts which show an atmosphere of sexual bias, such as: (1) failing to contract with a manufacturer capable of providing blazers for males and females; (2) using football references at training sessions; (3) showing a film to trainees containing scenes of a man defecating; and (4) providing different accommodations for female trainees. ... [D]uring training, males went to "strip bars" after the training sessions had ended. She contends that these acts, among others, reflect that Federated fostered an atmosphere of "masculine stereotypical personality traits." Id. at 810 n. 17 .

Although Torre's disparate impact claim was just one of many that she brought in a complicated and somewhat scattershot lawsuit which generated "voluminous submissions" on summary judgment, id. at 796, and has yet to be tried, her case is not entirely unrepresentative of the problems a disparate impact claim based on gendered characteristics must overcome.

285. The district judge in Sears "appl[ied] only the disparate treatment theory to [the] case" because he found "that the EEOC waived its right to pursue a disparate impact theory" by failing to give timely and proper notice of its intent to make such a claim. $628 \mathrm{~F}$. Supp. at $1285 \& \mathrm{n}$.7. The judge also found that the EEOC had failed to establish the basis for a disparate impact claim because it "admitted that it [could not] identify any specific employment practice of Sears which ha[d] a discriminatory impact on women." Id. at 1281. Although at the time the state of the law was unsettled, the Supreme Court has since made clear in Watson v. Fort Worth Bank \& Trust, 487 U.S. 977 (1988), that an employer's subjective decisionmaking can be challenged under a disparate impact theory, and $\S 703(\mathrm{k})(1)(\mathrm{B})(\mathrm{i})$ of Title VII, added by the 1991 Civil Rights Act, now provides that "if the complaining party can demonstrate to the court that the elements of a respondent's decisionmaking process are not capable of separation for analysis, the decisionmaking process may be analyzed as one employment practice." 42 U.S.C. $\$ 2000 \mathrm{e}-2(\mathrm{k})(\mathrm{B})(\mathrm{i})$ (1988 \& Supp. IV 1992).

286. Noting that "[w]hile it might not be intentional discrimination for an employer to require 'masculine' traits for a job, such a requirement could be subject to disparate impact attack if substantially more women than men are excluded," Michael Zimmer and his colleagues ask whether "the EEOC's attack against the 'masculine' work culture of the commission sales jobs at Sears [should] have been based on disparate impact analysis, rather than systemic disparate treatment." ZIMMER ET AL., supra note 269, at 272. They further note that "as Title VII is structured, differences between men and women are important for disparate impact analysis. As a consequence, they remain a two-edged sword. Professor Rosenberg's testimony could easily have been used on behalf of plaintiffs in . . . a disparate impact challenge." Id. at 509; see also Eichner, supra note 100, at 1404-07.

287. SUSAN FALUd, BACKLASH: THE UNDECLARED WAR AGAINST AMERICAN WOMEN 380 (1991). 
feminine in the construction of its work force, and indeed of its entire corporate image. Some of this change may have been prompted by the EEOC's lawsuit, although the evidence is ambiguous as to what extent Sears's affirmative action policy was a response to EEOC action. But much of the change is the result of a more recent marketing strategy self-consciously designed to attract and retain women as both employees and customers. Thus, when Sears was recently named one of Working Mother magazine's seventy-five best companies for women to work for, in large part for its newly flexible working hours and family care policies, it saw the designation as giving it "significant leverage in the recruitment of new employees." ${ }^{288}$ And in its merchandising, advertisements, renovations, expansion, and choice of product lines, the company is now stressing what it calls the "softer side of Sears"-actually making fun of its old masculine image in an effort to sell more "feminine" items to female customers. ${ }^{289}$

An even clearer case than Sears for the re-evaluation of an employer's use of gendered traits in the construction of a job and in the selection, training, and evaluation of those who perform the job was recently presented by the Los Angeles Police Department (LAPD), and it is on this example that I will center the rest of my disparate impact analysis. ${ }^{290}$ The job of police officer is one whose history of being gendered masculine is virtually unsurpassed. ${ }^{291}$ Police departments, many until recently de jure male, have been the target of numerous sex discrimination lawsuits, including both class actions successfully challenging the disparate impact on women of objective hiring criteria such as height and weight requirements and physical fitness tests; and suits by individual women challenging the perception, rooted in stereotypes, that they and their kind are unsuited to police work. ${ }^{292}$ Cases like Fadhl and Thorne, discussed above, represent the successful application

288. Amy Hauth \& Jane Humble, Family-Care Policies in the High-Tech Workplace, INDUs. MGMT., Nov. 1992, at 11, 12. Recall that Sears, in litigation, insisted that commission salespeople had to be on call at all hours and that this was a nondiscriminatory reason why few women took the job.

289. Recall that not only big ticket items, but virtually everything coded masculine, including men's apparel, was sold on commission during the years covered by the lawsuit, while women's apparel and most other "softer" items were not. The company's hiring manual matched its promotional materials from that era in representing "masculine" items and the commission salesmen who sold them at the pinnacle of the Sears enterprise. It is only since that time that the company has fully realized that "softer" items provide its strongest profit center and best source of growth patential. See, e.g., Susan Chandler, Sears' Turnaround Is for Real-For Now, Bus. WK., Aug. 15, 1994, at 102, 102-03; Maria Halkias, Sears' Softer-Side Concept Paying Off at Remodeled Stores, Dallas MORNing News, Nov. 22, 1994, at 4D. Sears has, in effect, done as Lucinda Finley suggested and re-evaluated its view that items "usually associated with women . . . [are] less 'important' and remunerative to sell." Finley, supra note 252, at 939.

290. I am grateful to sociologist Lynn Chancer for bringing the example of the LAPD to my attention.

291. Like so many jobs gendered masculine, it is also comparatively high paying. As compared with those available in traditionally female jobs, the financial rewards of policing are considerable, with the LAPD offering high school graduates starting salaries of approximately $\$ 35,000$. See John Johnson, Overburdened Police Struggle to Keep Up, L.A. TIMES, Aug. 3, 1995, at A1.

292. See supra text accompanying notes 127-29 (discussing Thorne v. City of El Segundo, 726 F.2d 459, 464-65 (9th Cir. 1983)); supra text accompanying notes 240-42 (discussing Fadhl v. City \& County of S.F., 741 F.2d 1163, 1165 (9th Cir. 1984)). 
to police work of an earlier generation of sex-stereotyping claims that focused on the stereotyping of individual employees. ${ }^{293}$ But, as noted above, these cases left the requirement of masculine characteristics in police work largely unchallenged; their focus was on demonstrating that notwithstanding stereotypes about women, individual women could meet the job's existing requirements.

Litigation has also been the motivating force for bringing the next generation of stereotyping claims-ones questioning the stereotypical gendered characteristics of the job rather than of individual applicants for it - to the attention of those who hire and evaluate the police. But the plaintiff whose case has been most influential in challenging the many ways in which the job of police officer has been gendered masculine is not a woman, not even an effeminate man. His claim was not one of sex discrimination. His name is Rodney King. In April 1994, King was awarded \$3.8 million in compensatory damages for his infamous beating by officers of the LAPD. ${ }^{294}$ More importantly, the fallout from the first criminal trial of the officers who beat him included riots that left nearly four dozen people dead and much of South Central Los Angeles in ruins. ${ }^{295}$ It may be too much to hope that the Rodney King incident will be the watershed event for gender discrimination that the Hill-Thomas hearings were for sexual harassment, but it provides in many ways a good start.

In the aftermath of the King incident, an independent commission headed by Warren Christopher was appointed to investigate the LAPD and its use of excessive force. The Christopher Commission found there to be "within the LAPD ... widespread and deeply felt gender bias ... result[ing] in the underutilization of female officers." ${ }^{296}$ According to the Commission, because there is "persuasive evidence that most female officers use a style of policing that minimizes the use of excessive force and inappropriate confrontations, the continued existence of discrimination against female officers can deprive the Department of specific skills and thereby contribute to the problem of excessive force."297 One way of characterizing the Commission's overall findings with respect to female police officers is in gendered terms: The Commission reported that while female officers' greater tendency to manifest feminine and avoid masculine behaviors actually caused

293. See supra Subsection IV.A.l for an analysis of the generations of sex stereotyping claims. For another case challenging the treatment of individual women in law enforcement, see Cathey v. Fowler, 57 Fair Empl. Prac. Cas. (BNA) 59, 60-61 (N.D. Ga. 1990) (supervisor repeatedly told female state trooper "women have no place in law enforcement," failed to provide her backup, assigned her typing duties in his home, and denied her leave "so that "the men could go hunting").

294. See Seth Mydans, Rodney King Is Awarded \$3.8 Million, N.Y. TIMES, Apr. 20, 1994, at A14.

295. See Robert Reinhold, Riot in Los Angeles: The Overview, N.Y. TIMES, May 3, 1992, at A1.

296. INDEPENDENT COMM'N ON THE L.A. POLICE DEP'T, REPORT OF THE INDEPENDENT COMMISSION ON THE LOS ANGeles POLICE DEPARTMENT 83 (1991) [hereinafter Christopher COMMISSION REPORT]. 297. Id. 
them to outperform male officers, the stereotypical expectation of male officers that policing called for masculine traits and that female officers lacked these traits caused male officers systematically to underrate the female officers' performance. Research on women and police work examined by the Commission

reveals that, while they perform as well as male officers, the main obstacle confronting female officers in all major metropolitan police departments continues to be male attitudes toward them, as well as the influence of stereotypical role models in law enforcement. Traditional views concerning the nature of police work in general-that is, that police work is a male oriented profession with a major emphasis on physical strength-foster a climate in which female officers are discouraged. A corollary of that culture is an emphasis on use of force to control a situation, and a disdain for a more patient, less aggressive approach. ${ }^{298}$

Specifically in the LAPD, the Commission found that "female LAPD officers are involved in excessive use of force at rates substantially below those of male officers. ... The statistics indicate that female officers are not reluctant to use force, but that they are not nearly as likely to be involved in use of excessive force."299 The Commission, relying on academic as well as anecdotal information, credited this to the female officers' ability to be "more communicative, more skillful at deescalating potentially violent situations and less confrontational. . . . Many officers, both male and female, believe female officers are less personally challenged by defiant suspects and felt less need to deal with defiance with immediate force or confrontational language. $\$ 300$

Notwithstanding their performance, as Chief Darryl Gates admitted, female officers "had a 'real tough time' achieving acceptance within the Department," with $70 \%$ complaining of "not being judged on ability."301 Indeed, the Christopher Commission reported that many training officers "expressed concerns that female officers were not as capable, effective or trustworthy as their male counterparts. ${ }^{1302}$ The training officers' specific objections tended to focus on a perceived lack of stereotypically masculine qualities. They complained that women "tend to be smart and good at writing

298. Id. at 88.

299. Id. The Commission cited data, subsequently widely reported in the press, that no women were among the 120 officers with the most use-of-force reports or the 132 who ranked highest in combined useof-force reports, complaints, and officer-involved shootings. Although nearly $14 \%$ of the force, female police officers represented only $3.7 \%$ of the 808 officers with the highest number of such incidents. The percentage of women was also disproportionately low with respect to the other measures of excessive force considered in the Report. For example, of those involved in incidents leading to serious lawsuits against the LAPD, only $3.4 \%$ were women. Id. at 83-84.

300. Id. at 84 .

301. Id. at 85 .

302. Id. at 86 . 
reports, but are weak and timid,"303 "not as strong," and lack the "physical stature" 304 and "upper body strength"305 to do the job. These stereotypical negative evaluations indicate that, on one level, little has changed since the El Segundo police force evaluated Deborah Lynne Thorne as too "feminine" for the job on the basis of stereotypes alone and in the absence of any objective evidence of her alleged deficiencies. ${ }^{306}$

On another level, however, there is a world of difference between the Christopher Commission Report and the approach of the Ninth Circuit in Thorne, discussed above. Recall that the Ninth Circuit did not question the El Segundo police's view that to qualify as a police officer, Thorne would need to "display sufficient aggressiveness, self-assuredness or probable physical ability to presently handle herself in stress situations"307; they just found that the only evidence that she lacked those qualities was a stereotypical inference from the mere fact that she was a woman. By contrast, the Christopher Commission Report, like so much of the evidence generated by experts, commissions, and litigation in the years since Thorne, calls into question, not so much whether women are aggressive, but whether aggressiveness is a useful quality in a police officer. ${ }^{308}$ Instead of insisting that women manifest masculine qualities to succeed in police work, the Christopher Commission focused on how much more effective feminine qualities are than masculine qualities in the work of the police and concluded that, because women are disproportionately likely to display those qualities, they and the qualities associated with them should be more heavily represented and highly valued on police forces.

303. Id.

304. Id. at 87.

305. Id.

306. See Thorne v. City of El Segundo, 726 F.2d 459, 465-68 (9th Cir. 1983); supra text accompanying notes $127-29$.

307. Thorne, 726 F.2d at 467.

308. See, e.g., THE WOMEN's AdVISORY COUNCIL to THE L.A. POLICE COMM'N, A BLUEPRINT FOR IMPLEMENTING GeNDER EQUiTy IN THE Los ANGelles Police DEPARTMENT app. G at 6-8 (1993) [hereinafter WAC BLUEPRINT] (citing PATRICIA W. LUNNENBORG, WOMEN POLICE OFFICERS-CURRENT CAREER PROFILES 110 (1989)) (summarizing data on gender and policing styles showing women officers are less aggressive and confrontational, are more polite, gentle and compassionate, depend more on verbal skills, and better handle service and domestic calls, public contacts, and community relations); Carol A. Martin, Women Police and Stress, POLICE CHIEF, Mar. 1983, at 108, 108 ("Quite often if the male officer is of the John Wayne-type he will provoke a fight or violence, instead of calming down the situation."). Many of the experts recommended that male police officers learn from women to avoid an excessively masculine style and to acquire a more feminine one. See, e.g., WAC BLUEPRINT, supra, app. G at 8-9 (quoting Katharine Van Wormer, Are Males Suited to Police Patrol Work?) (recommending special selection and training to overcome gender "shortcomings" of male police recruits); Lewis J. Sherman, $A$ Psychological View of Women in Policing, 1 J. OF POLICE SCI. \& ADMIN. 383, 384 ("The less violent behavior of policewomen would spill over on policemen, who would learn that a decrease in muscularity often leads to an increase in efficiency."); $c f$. Berkman v. City of N.Y., 536 F. Supp. 177, 212 \& n.23 (E.D.N.Y. 1982), aff'd in part and rev'd in part, 812 F.2d 52 (2d Cir. 1987) (criticizing emphasis on speed in test for firefighters that had disparate impact on women, whose endurance was better than their speed, because evaluations of actual job performance showed that "aggressiveness" and moving too rapidly were dangerous, rather than useful, in firefighting). 
In addition to analyzing gender bias and its consequences in the LAPD, the Christopher Commission made a number of specific recommendations that can be summed up as a call to "feminize the force." criticized specific "macho" tactics of the police and police academy training that overemphasized the paramilitary and physical and underemphasized interpersonal skills, sensitivity, politeness, and the ability to communicate. The recommendations in the Report were seized upon by the Women's Advisory Council to the LAPD, which issued its own lengthy Blueprint for Implementing Gender Equity in the LAPD in October 1993, ${ }^{310}$ as well as by the Los Angeles City Council, which passed a resolution calling for an increase in the percentage of women in the LAPD to $43 \%{ }^{311}$

The Blueprint's key recommendations include the following:

Immediately [g]ender balance all Police Academy classes .... . ... Eliminate discriminatory and irrelevant exercises ... that unnecessarily exclude women applicants from joining the LAPD. ... Ensure that all LAPD performance criteria and exercises are evaluated by external experts for adverse impact on women. . . . ... Expedite and improve training to prevent sexual harassment, sex discrimination and perpetuation of the anti-female environment documented in the Christopher Commission Report.

....

... Establish an Assessment Center promotion system that promotes on the basis of performance.... Validate all promotion criteria and testing tools and procedures for gender bias. ${ }^{312}$

An examination of the over 100 far more specific recommendations of the Blueprint indicates that they can be summed up as calling straight down the line for less masculine and more feminine criteria for hiring and evaluation of police, with the assumption that to do so would both increase the number of women on the force and improve overall police performance. This recommended move away from masculine and toward feminine criteria applied to all aspects of recruitment, training, performance, and evaluation. ${ }^{313}$

309. See Gloria Ohland, Feminize the Force: Gender Balancing-and Debrutalizing the LAPD, L.A. WKLY., Mar. 6, 1992, at 15 (reporting studies "offering strong evidence that women officers are more likely to calm potentially violent situations and avoid injuries to all participants," that "[p]olicemen see police work as involving control through authority, while policewomen see it as a public service," that "[e]ffective law enforcement requires intelligence, not strength," that "[n]o research shows that strength is related to an individual's ability to successfully manage a dangerous situation," and that women in "the patrol forces would diversify attitudes and break down the squad-room set of values").

310. WAC BLUEPRINT, supra note 308.

311. See Marc Lacey, Council Raises Hiring Goal for Women Officers, L.A. TiMES, Apr. 14, 1994, at B3.

312. WAC BLUEPRINT, supra note 308 , at 13.

313. It is important to note in examining these and similar recommendations that de-emphasizing masculine criteria and emphasizing feminine ones is a two-step process. Recall that psychological theory no longer considers masculinity and femininity on a continuum, with any decrease in one necessarily resulting in an increase in the other. See Figures 1 and 2. Here, the Blueprint is calling for both a move 
As to recruitment, the Blueprint found that:

An underlying acceptance of the myth that "women don't want to be police officers" is in part responsible for several recruitment approaches which have actively served to limit . . . the number of women recruits. ...

-..

Recruitment materials reflect a prevailing notion of policing as a rough-and-tumble career for which only "John Waynes" need apply. ${ }^{314}$

It specifically recommended shifting from the-masculine to the feminine in how, where (e.g., sporting events vs. daycare centers), and whom (e.g., security guards vs. social workers) the LAPD recruited. ${ }^{315}$ Similarly, it recommended that both the job description and the evaluation of candidates' prior experience and skills should shift to reflect the new emphasis on community policing. ${ }^{316}$ Finally, as to promotion, the Blueprint observed:

away from the masculine and a move toward the feminine. If the prior emphasis on masculine qualities in police officers is thereby reduced but not eliminated, and a new emphasis on feminine ones is added, the result should be, on Bem's schema, a strongly androgynous police officer, but one leaning more strongly toward the feminine than previous conceptions of androgyny favored.

314. WAC BLUEPRINT, supra note 308 , at 24.

315. Id. at 24-27. The Blueprint detailed the problems of the current recruitment process:

Recruitment activities are frequently targeted at military bases and the armed forces . . . and at male-audience sporting events, rather than occupations dominated by women.

... The Department gives preference to recruits with backgrounds in mostly male-dominated fields such as security guard and athlete rather than female-dominated fields such as school teacher and social worker.

Id. at 24. It then went on to offer some solutions:

Locate new sources of female candidates by targeting populations of women in traditionally female-dominated occupations such as teachers, nurses, day-care workers, secretaries, social workers, clerical support personnel, civilian members of the police force and other city agencies.

....

... Discontinue LAPD recruitment activities at military bases since women represent only $11.5 \%$ of the total armed forces.

....

... Recruitment efforts should also target institutions frequented by women such as schools, child care centers, [community colleges] and events with predominantiy female audiences.

Id. at 26. Recruiters should stress "the financial rewards, security and public service of a job on the police force," id. at 25, "refrain from overemphasizing the danger and physical strain," $i d$, and "[e]mphasize in all recruitment... materials the need for abilities in problem-solving, communication, community involvement, self control under stress, and good judgment," id. at 27.

316. Id. at 29-30. The Blueprint recommended that the LAPD "[r]e-write the job description for police officer ... to reflect the new emphasis on community policing and to ensure that they are free from bias against women and other groups." Id. at 19. It then made several other recommendations:

... Revise the criteria for evaluating previous work experience and educational background of candidates to reflect the changing job description and new mix of desired skills in the police force.

Oral interview panelists frequently place a greater value on previous experience as a security guard or military personnel rather than as a teacher or social worker.

... Evaluate all tests and interviews for gender bias and relevance to job performance. ... .... 
"Women applicants are measured against a gender biased vision of a good police officer or supervisor that includes criteria like physical stature as an element of 'command presence' sought by evaluators on the oral interview boards." 317 The Blueprint went on to recommend: "Review all promotional examination criteria for gender bias. This includes criteria such as the definition of 'command presence,' 'appropriate use of force' and other commonly used terms. Clear emphasis must be placed on community policing skills like negotiation and problem solving." ${ }^{\text {"318 }}$

What the Christopher Commission Report and the Women's Advisory Council Blueprint together set forth are some of the kinds of evidence necessary to bring a disparate impact claim of gender-based discrimination. Not only do they suggest a disparate impact on women from both the emphasis on masculine and the exclusion of feminine traits, they even more clearly show a lack of business necessity for favoring the masculine. If the proposed reforms are implemented and the LAPD in fact becomes more effective, this evidence, too, can be used by women in other cities to challenge the standards imposed by their police forces. Faced with this sort of evidence, a future court might well say about some of the more subjective masculine standards used in evaluating police what an earlier court said in striking down more objective physical criteria: "The defendants are promoting the masculine authority image. They advance the traditional stereotype of a police officer as the man-with-the-gun fighting crime. We do not agree with those theories." ${ }^{3319}$

One of the many things the example of police work makes clear is how often gendered requirements come bundled. While it is important in litigation for potential gender discrimination plaintiffs to begin by specifically identifying, one by one, the gendered characteristics required of them and the way those requirements are used in making employment decisions rather than simply to make generalized allegations about "sexual bias" or the "gendering of the job," it is also worth noting that gendered job requirements are rarely found in isolation. Rather, for the LAPD, as well as for commission sales at Sears, an overall masculine conception of the job led at one and the same time to: (a) describing the desired personality traits for hiring and evaluation with adjectives coded masculine-aggressive, assertive, etc.; (b) recruiting persons with masculine backgrounds or interests-football and wrestling as well as auto mechanics for Sears, the military for the LAPD; (c) failing to use

... Studies have shown that 80 to 95 percent of policing involves non-violent or serviceoriented activities, and that physical strength is not related to job performance. Yet physical Id. at $29-30$.

strength continues to be a central focus of recruiting and training ....

317. Id. at 37 .

318. Id. at 38.

319. Brace v. O'Neill, 19 Fair Empl. Prac. Cas. (BNA) 849, 853 (E.D. Pa. 1979). 
potentially applicable "feminine" ways of characterizing the job or evaluating performance, ${ }^{320}$ and (d) insisting as well on physical attributes highly correlated with maleness-secondary sex characteristics such as a "low-pitched voice" at Sears, height and weight in the LAPD. ${ }^{321}$

Challenging the more subjective masculine criteria imposed on police officers-"aggressiveness," "self-assuredness," "officer bearing"-is the logical next step to challenging height, weight, and physical fitness standards. In both cases, proxy bias and stereotypical conceptions of the job, rather than anything like business necessity, may have led to the imposition of the challenged requirements. ${ }^{322}$ There is evidence to suggest that both the

320. See, e.g., Leisner v. New York Tel. Co., 358 F. Supp. 359, 365 (S.D.N.Y. 1973) (granting preliminary injunction on disparate impact claim where employer who required "objectively demonstrated skills of leadership" and "significant supervisory experience" considered military service but did not consider teaching to satisfy these criteria). I have recently and unsystematically conducted the thought experiment of positing that for any particular job, qualities helpful to success can be described in either masculine or feminine terms, in the hopes of uncovering strong counterexamples, but none has yet emerged. Briefly consider, for example, the job of law professor. The Socratic method, to take just one conventional aspect of the job, is described by some as the exertion of a masculine control over the classroom; recall, however, that Socrates himself described his function as that of a midwife, helping knowledge to emerge from within his interlocutor as a child does from its mother's womb. See PLATO, THEAETETUS 149-51 (Bernard Williams ed., 1992); cf. Jeanne L. Schroeder, Feminism Historicized: Medieval Misogynist Stereotypes in Contemporary Feminist Jurisprudence, 75 IowA L. REV. 1135, 1141 n.12 (1990) (noting that responses of Carol Gilligan's Jake and Amy can be recharacterized so as to make Amy's more logical and analytic, Jake's more relational). My colleague Paul Mahoney points out that the job of football quarterback, conventionally described as requiring such masculine qualities as confidence, decisiveness, stoicism, and strength, can also be described as requiring a feminine sensitivity to one's teammates, for example, knowing who is having a good day and who a bad day. For further examples of how the characteristics of a job, and good performance in it, can be described in either masculine or feminine terms, see ROSABETH MOSS KANTER, MEN AND WOMEN OF THE CORPORATION (1993) and Finley, supra note 252, at 939. See also Survivors Praise Flight Attendant; She Acted with Calm Efficiency Before Commuter Crash, CHI. TRIB., Aug. 24, 1995, at 11 (praising flight attendant for "behav[ing] like a drill sergeant" in her "calm," "purposeful," and "reassuring" preparation of passengers for plane crash). How much would it matter to the selection, evaluation, and performance of employees whether performance criteria were described in masculine, feminine, or neutral terms, or in some combination? The historical and cultural examples of jobs that have changed their gender may give some indication. See supra note 100 . It may well be that what you see is what you get.

321. For a rare example of the potentially discriminatory bundling of feminine characteristics as job requirements in a predominantly female job, see discussion of the Jenny Craig case, supra note 96.

322. See, e.g., Ruth Colker, Rank-Order Physical Abilities Selection Devices for Traditionally Male Occupations as Gender-Based Employment Discrimination, 19 U.C. DAVIS L. REV. 761, 796 (1986) ("IJ]urisdictions have chosen test items that emphasize traditionally male-valued speed and strength, ignoring actual job requirements. When a job analysis in New York revealed that traditionally female-valued traits are useful, those results were ignored."). For an example of a test validated by experts that was nevertheless rejected because it was explicitly considered too feminine, see Berkman v. City of N.Y., 536 F. Supp. 177 (E.D.N.Y. 1982), aff'd in part and rev'd in part, 812 F.2d 52 (2d Cir. 1987). In that case, the fire department's "so-called twist-and-touch test for the ability of extent flexibility and the balance test for gross body equilibrium were the subject of complaints by then-Commissioner O'Hagan ... . on the ground that what was wanted was a test 'for firefighters, not for ballet dancers."' Id. at 196. The court noted that "[i]ronically, among the relatively neutral job anchors used by [expert] Dr. Fleischman in his job analysis, the abilities of ballet dancers were recognized as one reliable ind[ex] of human abilities common to ballet dancers and firefighters." Id. at 196 n.15. As concrete examples of the required physical ability of "gross body coordination," Fleischman had used the ability to "do a skilled ballet dance like Swan Lake" as well as the ability to "make a lay up shot in the basketball game." Id. at 187. As examples of "extent flexibility," he had listed "side show lady bends herself into a pretzel shape" as well as "do[es] a modern dance." Id. By contrast, tests like scaling a wall, which resulted in the exclusion of a disproportionate number of women and which involved skills rarely required on the job, were included in 
requirement that police officers be tall and the requirement that they be aggressive may not only not be validated, but may actually bear an inverse relationship to good job performance. ${ }^{323}$ Although it was not until an adverse Ninth Circuit decision ${ }^{324}$ led to the Fanchon Blake consent decree that the LAPD made a commitment to eliminate male-biased height requirements, the problems identified by the Christopher Commission and the Women's Advisory Committee have thus far been addressed by City Council resolution and by the endorsement of the police commissioner, not by litigation. Indeed, avoiding litigation of all sorts was a prime benefit the Blueprint predicted when it recommended that the LAPD "[f]ind additional resources to expand female recruitment and achieve gender equity in order to reduce payments for lost productivity, costly sex discrimination and excessive force lawsuits later." ${ }^{325}$

I am delighted to see in the actions of the city of Los Angeles a potential vindication of my hope that voluntary employer action may forestall the need for litigation to combat the disparate impact of certain forms of gender discrimination. Yet, I would also argue that, in a very important sense, the conclusion apparently drawn by the Los Angeles City Council that to make the police force more feminine it is both necessary and sufficient to make it more female is a facile mistake. In the language of the law, it is to assume, in effect, that if feminine traits are necessary for the job, being female can be a BFOQ; in the language of feminist theory, it is to essentialize the female as feminine. This sort of mistake was repudiated by earlier courts in cases such as Diaz v. Pan American World Airways and Button v. Rockefeller. ${ }^{326}$ In Button, the court rejected the claim that female sex was a BFOQ for duties such as investigating sex crimes or interrogating or transporting women prisoners. The court acknowledged that certain forms of police work "will often require great sensitivity and perhaps empathy" but held that "it cannot

\footnotetext{
the city's proposed exam simply on the basis of:

a subjective feeling on the part of City personnel that firemen should be able to do these things.

As the EEOC guidelines wisely inform us, such seat-of-the-pants justifications for employment

tests may well be the source for the stereotyped images of jobs which exclude women without

there being a rational reason for their exclusion.

Id. at $195 \mathrm{n} .13$.
}

323. See, e.g., Officers for Justice v. Civil Serv. Comm'n, 395 F. Supp. 378, 381 (N.D. Cal. 1975) (striking minimum height requirement for police and reporting that results of survey of relationship of height to assaultive conduct against police officers, to number of citizen complaints against them, to number of injuries sustained by them in performance of their duties, and to their use of excessive force "either tend to indicate better results from shorter officers or are too inconclusive to support any finding"); Smith v. City of E. Cleveland, 363 F. Supp. 1131, 1144 (N.D. Ohio 1973) (concluding that height and weight requirements for police were "based solely on the stereotype of the large male police officer" and lacked rational basis).

324. Blake v. City of L.A., 595 F.2d 1367 (9th Cir. 1979).

325. WAC BLUEPRINT, supra note 308 , at 28.

326. Diaz v. Pan Am. World Airways, 442 F.2d 385 (5th Cir. 1971); Button v. Rockefeller, 351 N.Y.S.2d 488 (Sup. Ct. 1973). For a discussion of these cases, see supra note 254. 
be said as a general proposition that these qualities are inherent in women and lacking in men." 327

I would personally welcome the day when the LAPD is $43 \%$ female, but I would welcome even more the day when $100 \%$ of the LAPD has abandoned the destructive macho approach to policing criticized by the Christopher Commission in favor of a more constructive one. ${ }^{328}$ Just as women have learned to manifest the masculine qualities thought necessary for success in various fields in the past, I hope that the men as well as the women of the LAPD can learn the feminine ones that are gradually coming into favor. That does not mean that I see no specific advantages for female job applicants in the move toward a more feminine LAPD. In the short term, precisely because women as presently constructed are more likely to display the qualities sought by the Christopher Commission, instead of those qualities it criticized, changing the criteria for hiring, testing, evaluation, and promotion in line with the Commission's recommendations will likely lead to the hiring and promotion of more women. In the medium term, if California (or indeed the United States) does pass legislation banning affirmative action (that is to say clearly prohibiting sex from being taken into account in hiring decisions), the hiring of women by the LAPD should not be adversely affected, as it would be if sex and not gender were the underlying concern of proposals like that adopted by the Los Angeles City Council. The city of Los Angeles will not be hiring more women because they are women, but rather because they manifest qualities necessary for their job. And police chiefs of the future can say to men what their predecessors said to women in the past: when your sex manifests the qualities we need in the same proportion as the opposite sex does, you will be hired in the same proportion; at present we hire as many women as we do, not as affirmative action, but out of business necessity.

\section{BEYOND TITLE VII (AND BEYOND SAMENESS AND DIFFERENCE?)}

Thus far in discussing legal approaches to gender discrimination, I have focused almost exclusively on the employment context and Title VII cases. Yet not only the gender issues raised in those cases, but the concepts of sex stereotyping that inform the courts' discussion of them, are central as well to the Supreme Court's constitutional sex discrimination jurisprudence. Under

327. Button, 351 N.Y.S.2d at 492.

328. I want it to be clear that in focusing on the "feminization of the force" I by no means intend to suggest that we should simply turn the world upside down and accord feminine characteristics the preeminence once accorded masculine ones. Rather, I hope, first, that police officers of both sexes do not abandon positive masculine qualities as they add positive feminine ones to their repertoire, and second, that we come to appreciate more fully that there can be "many gifts, but the same spirit," 1 Corinthians 12:4-many different ways of doing different jobs well. 
Title VII, the Court has long held that "“[i]n forbidding employers to discriminate against individuals because of their sex, Congress intended to strike at the entire spectrum of disparate treatment of men and women resulting from sex stereotypes." ${ }^{329}$ And, as I have shown, it has gradually expanded its conception of what constitutes sex stereotyping as it has been faced with increasingly complex and subtle barriers to the equality of the sexes.

As I noted at the beginning of my discussion of sex-stereotyping doctrine in Subsection IV.A.1, it appears that the Supreme Court imported the language of opposition to sex stereotyping into constitutional cases from the Title VII context. ${ }^{330}$ In the Title VII context, as I have discussed, stereotyping takes place when a rule is made about a group on the basis of less than universal generalizations about that group, and no room is left for individual exceptions to the rule. And, under Title VII, it has become clear that an employer must leave room for such exceptions-to fail to do so is to violate the statute, which, the courts have held, prohibits acting on stereotypes to the detriment of individuals who deviate from stereotypical expectations. As Justice Brennan put it in his Hopkins opinion, "As for the legal relevance of sex stereotyping, we are beyond the day when an employer could evaluate employees by assuming or insisting that they matched the stereotype associated with their group." ${ }^{\text {"331 }}$

The constitutional status of sex stereotyping is somewhat less clear than its status under Title VII. Is a state actor under the Constitution prohibited to the same extent as an employer under Title VII from "evaluat[ing individuals] by assuming or insisting that they match[] the stereotype associated with their group"? Certainly pronouncements of opposition to stereotyping are at least as pervasive in constitutional as in Title VII opinions. ${ }^{332}$ But, in the constitutional context, the Supreme Court has not yet been forced to articulate with analytic clarity the status of sex stereotyping. Is the Court's language of opposition to it a mere rhetorical flourish added on to decisions made on other grounds or can it be seen as part of a meaningful legal doctrine, as it is in the Title VII context? What exactly constitutes "sex stereotyping" in constitutional law and how much of it is prohibited? $?^{333}$ In particular, does

329. Los Angeles Dep't of Water \& Power v. Manhart, 435 U.S. 702, 707 n.13 (1978) (quoting Sprogis v. United Air Lines, Inc., 444 F.2d 1194, 1198 (7th Cir. 1971)).

330. See supra note 116 .

331. Price Waterhouse v. Hopkins, 490 U.S. 228, 251 (1989).

332. See, e.g., J.E.B. v. Alabama ex rel. T.B., 114 S. Ct. 1419, 1422 (1994) ("Today we reaffirm what, by now, should be axiomatic: Intentional discrimination on the basis of gender [i.e., sex] by state actors violates the Equal Protection Clause, particularly where... the discrimination serves to ratify and perpetuate invidious, archaic, and overbroad stereotypes about the relative abilities of men and women.").

333. Justice Scalia raises this question fairly explicitly in his J.E.B. dissent. He begins by acknowledging that the Court seems to view as impermissible stereotyping any use of sex as a less than perfect proxy, even in cases where it "was a remarkably good predictor." Id. at 1436 (Scalia, J., dissenting). But he goes on to wonder whether "perhaps when the Court refers to 'impermissible stereotypes,' ... it 
the Constitution prohibit to the same extent as Title VII sex discrimination based on gender stereotypes, such as the assumption that women are or should be feminine and men masculine ? $^{334}$

Two related cases before the Court this term may force it to confront more explicitly than it has in the past "the legal relevance of sex stereotyping" for constitutional law. These well-publicized cases challenge as violative of the Fourteenth Amendment Equal Protection Clause the continued per se exclusion of women from two state-sponsored military colleges, the Virginia Military Academy (VMI) and The Citadel of South Carolina. ${ }^{335}$ Like the job of police officer, the job of soldier has become both more female and more feminine in recent years. Not only have women been entering the services and the U.S. military academies in record numbers, but recent military assignments have extended well beyond traditional combat to, for example, the distribution of food and relief supplies to the people of Somalia. ${ }^{336}$ U.S. soldiers performed policing functions not only in Haiti and Somalia, but also in riot-torn Los Angeles, where citizens praised them as a far more comforting and nurturing presence than the LAPD, and even held their work up as a model for community policing. ${ }^{337}$ For more than a century, VMI and The Citadel have taken as their mission the training of "citizen-soldiers" for this country. But though the job of a citizen-soldier may have changed in the last century, neither school has any intention of changing either its masculine methods or its all-male admissions policy. The Citadel opposed to the last a court order that it admit Shannon Faulkner as a student

means the adjective to be limiting rather than descriptive-so that we can expect to learn from the Court's peremptory/stereotyping jurisprudence in the future which stereotypes the Constitution frowns upon and which it does not." Id. at 1438 (Scalia, J., dissenting) (citations omitted).

334. Of the many things that may help account for the differences in both the breadth and the clarity with which the Supreme Court has repudiated "the entire spectrum of disparate treatment of men and women resulting from sex stereotypes" in the Title VII and constitutional contexts, two are perhaps most important: First, unlike the Constitution, Title VII has a text that quite explicitly prohibits distinctions in treatment between the sexes, generally mandating a sameness approach to sex equality; and second, the disparate impact theory available under Title VII is not available under the Constitution, where an invidious discriminatory purpose has been held to be required. See Washington v. Davis, 426 U.S. 229 (1976).

335. Petitions for certiorari filed by parties on both sides of both cases were before the Court at the time this Article went to press. See Jones v. Faulkner, petition for cert. fled, 64 U.S.L.W. 3122 (U.S. Aug. 11, 1995) (No. 95-258); Faulkner v. Jones, petition for cert. filed, 64 U.S.L.W. 3126 (U.S. July 10, 1995) (No. 95-31); Virginia v. United States, petition for cert. filed, 64 U.S.L.W. 3001 (U.S. June 23, 1995) (No. 94-2107); United States v. Virginia, petition for cert. filed, 63 U.S.L.W. 3861 (U.S. May 26, 1995) (No. 94-1941).

336. See, e.g., David C. Morrison, Operation Kinder and Gentler, NAT'L J., May 25, 1991, at 1260 (describing humanitarian missions of U.S. military, such as Operation Provide Comfort, providing relief supplies to Kurdish refugees, and Operation Productive Effort, helping Bangladeshi cyclone survivors); Mark Thompson, Mission Underlines New Scope of U.S. Military After Cold War, HousTon CHRON., Dec. 5, 1992, at A25 (quoting General Colin Powell describing U.S. military role in Somalia as that of "a helpful, supportive, humanitarian army that will take care of human needs").

337. See, e.g., Jack Miles, Blacks vs. Browns; African Americans and Latinos, THE ATLANTIC, Oct. 1992, at 41, 41 ("During the riot the National Guard . . . was far more like a community police force than the community's own police force. The news photographs-Guardsmen talking to children .... and so forth-were of scenes that would be noticeably out of character for the hard-assed LAPD."). 
and as the first female member of its corps of cadets. ${ }^{338}$ As for VMI, it responded to the Fourth Circuit's holding that the school and the state of Virginia were denying women the equal protection of the laws ${ }^{339}$ with a remedial plan that would maintain the school's state-sponsored all-male/masculine status unchanged.

The Fourth Circuit presented both VMI and The Citadel with three basic options for remedying the constitutional violation caused by their exclusion of women-admit women, abandon state support, or establish parallel institutions or parallel programs. VMI chose the last of these options, in the form of the Virginia Women in Leadership program (VWIL) to be established at Mary Baldwin College, a private women's college about thirty-five miles from VMI. ${ }^{340}$ Similarly, The Citadel proposed subsidizing a "women's leadership program" called the South Carolina Institute of Leadership for Women (SCL) at a nearby private women's school, Converse College, ${ }^{341}$ although it could not get this plan approved in time to avoid Faulkner's courtordered admission. In presenting remedial options, the Fourth Circuit did not "direct that any parallel program ... be identical for both men and women." ${ }^{342}$ The court said any parallel program

must take into account the nature of the difference on which the separation is based, the relevant benefits to and the needs of each gender, the demand (both in terms of quality and quantity), and any other relevant factor. In the end, distinctions in any separate facilities provided for males and females may be based on real differences between the sexes, both in quality and quantity, so long as the distinctions are not based on stereotyped or generalized perceptions of differences. ${ }^{343}$

Notwithstanding the caveat against stereotyping, the VMI district court on remand then went on to approve a plan that was in every detail based on gender stereotypes: The plan assumes, first, a perfect identity between sex and

338. See Faulkner v. Jones, 10 F.3d 226 (4th Cir. 1993). Faulkner's brief matriculation in mid-August 1995 followed the last-minute rejection by Justices Rehnquist and Scalia of The Citadel's requests for relief from the order admitting her. She withdrew from the school after spending most of the first week of new cadet training, generally known as "hell week," in the school's infirmary suffering from severe nausea, which she described as a physiological reaction to the accumulated stress of her years in litigation. See Debbi Wilgoren, Female Cadet Leaves Citadel, WASH. POST, Aug. 19, 1995, at A1.

339. See United States v. Virginia, 976 F.2d 890, 900 (4th Cir. 1992) (VMI I).

340. See United States v. Virginia, 44 F.3d 1229, 1233 (4th Cir. 1995) (VMI II).

341. See Citadel Offers Plan to Avoid Female Cadets, N.Y. TIMES, Oct. 7, 1994, at A26. A trial on the adequacy of this remedy in the Citadel case has been scheduled for November 1995 and, if the plan is approved, it will preclude the admission of any woman other than Faulkner to The Citadel. The Converse College program began this September with funding that will not continue unless the court approves the program as an alternative to the admission of women to The Citadel. See Linda L. Meggett, Converse Takes Different Approach, CHARLESTON POST \& COURIER, Aug. 31, 1995, at A1.

342. Faulkner, 10 F.3d at 232.

343. Id. (characterizing decision in VMI $\mathrm{I}$ ). 
gender and, second, a near perfect dichotomy between genders. ${ }^{344}$ That is to say, it proceeds from the premise that all men are gendered masculine, all women gendered feminine, and masculine and feminine are in most respects polar opposites. Then, taking VMI as presently constituted as embodying one polar ideal type, the program for masculine men, it approves construction of an opposite pole-a program to turn feminine women into leaders as well. The details of the plan are eerily reminiscent of psychological studies of masculinity and femininity. ${ }^{345}$

VMI, a military school, relies on what it calls the "adversative method" to train its cadets. ${ }^{346}$ Yet,

[a]fter a detailed study of the appropriate methods by which the leadership program should be structured, the Task Force determined that a military model and, especially VMI's adversative method, would be wholly inappropriate for educating and training most women for leadership roles. . . . In lieu of the adversative methods employed by VMI, the VWIL concept proposes a cooperative method which

344. See, e.g., United States v. Virginia, 852 F. Supp. 471, 480 (W.D. Va. 1994) (VMI II) (suggesting women at age of matriculation have less confidence in themselves than men of similar age).

345. One might also be tempted to note a resemblance to the work of scholars such as Carol Gilligan, who has outlined what she sometimes claims are fundamentally different approaches to moral reasoning on the part of men and women. See generally CAROL GILLIGAN, IN A DIFFERENT VOICE (1982). This, Gilligan's most famous book, outlines two forms of moral reasoning she dubs the "ethic of justice" and "the ethic of care." While Gilligan usually resists calling the former male and the latter female, the former is clearly gendered masculine and the Iatter feminine. Moreover Gilligan occasionally, and some feminist legal scholars who apply her work more often, fall into the (to my mind dangerous) habit of speaking as if there were something essentially male or female about the two voices, as if the voice of care were the voice of women pure and simple (not of some women, as Gilligan's research suggests; let alone potentially of all human beings, as Gilligan seems to hope), and its emphasis on connectedness to and concem for others is essentially rooted in, among other things, women's reproductive biology. See, e.g., Carol Gilligan, Moral Orientation and Moral Development, in WOMEN AND MORAL THEORY 19 (Eva F. Kittay \& Diana T. Meyers eds., 1987) (observing that, when asked to describe a moral dilemma, one third of women focused on care, one third on justice, and the remainder balanced the perspectives of justice and care); Robin West, Jurisprudence and Gender, 55 U. CHI. L. REV. 1, 2-3 (1988) (describing women as "essentially connected" to others both morally and "materially, through pregnancy, intercourse and breast-feeding" and men as "essentially separate"). Gilligan's own normative preference seems usually to be an integration of the two voices, both in the culture generally and within all human beings-this is the result she analogizes to a boy and girl's playing together the new game of the pirate who lived next door. See supra note 74. This is particularly interesting in light of Judge Kiser's assertion in VMI that the result of training females in a feminine style and males in a masculine style will have the purpose and effect, not of further polarizing the sexes or genders from each other, but of bringing them closer together, of supplying to each elements of the other that they initially may have lacked. See infra text accompanying note 350 .

It is important to note that, although VMI cited Gilligan's work in support of its plan, Gilligan herself "repudiate[d] the implication that her research supports VMI's contentions" in an amicus brief she sought leave to file before the Fourth Circuit. Opposing All-Male Admission Policy at Virginia Military Institute: Amicus Curiae Brief of Professor Carol Gilligan and the Program on Gender, Science, and Law, 16 WOMEN's RTS. L. REP. 1, 13 (1994). The positions set forth in this brief seem to me entirely consistent with and in many respects similar to those set forth in the relevant portions of this Article.

346. The gruesome details of the adversative model are set out in the two VMI district court opinions, as well as in numerous press accounts of the case. For a further flavor of the model, see, e.g., Faludi, supra note 204, at 62,67-70. One of VMI's expert witnesses felt that if VMI were to admit women, it would eventually find it necessary to drop the adversative model altogether, and adopt a system that provides more nurturing and support for the students. VMI I, 766 F. Supp. 1407, 1413 (W.D. Va. 1991). 
reinforces self-esteem rather than the leveling process used by VMI. VWIL will be a highly structured program but without the extreme adversative VMI components, such as the rat line and breakout. In the opinion of one of the leading experts on the educating of women, Dr. Elizabeth Fox-Genovese, an adversative method of teaching in an allfemale school would be not only inappropriate for most women, but counter-productive. Dr. Fox-Genovese's opinion is based on her extensive research which shows that most women reaching college age generally have less confidence than men. It is the opinion of the Task Force that the methods adopted for the VWIL will produce the same or similar outcome for women that VMI produces for men. ${ }^{347}$

In other words, as the VMI program is gendered masculine, so the VWIL program approved by the district court will be gendered feminine. One will take overly atomistic males and beat them into a cohesive unit; the other will gently nurture the individuality and self-esteem of females. ${ }^{348}$ These genderspecific methods are intended to lead, one might argue, to a more androgynous result, since as a result of being treated in a feminine way, the girls are meant to develop qualities coded masculine, while masculine methods are used to achieve feminine connectedness in the boys. ${ }^{349}$ In the

347. VMI II, 852 F. Supp. at 476 . The rat line is "a seven-month regimen, comparable to Marine boot camp, during which first-year cadets, or 'rats,' are 'treated miserably,' like 'the lowest animal on earth." Petition for Writ of Certiorari at 3, United States v. Virginia (No. 94-1941).

348. According to one of VMI's expert witnesses, Dr. Wilson, "women do not need the leveling experience of a rat line and adversative methods and ... women are generally raised with a lower self-image than men." VMI II, 852 F. Supp. at 480 n.10. The VWIL House will not be operated on a military format. Id. at 477 . It will include training in "self-defense and self-assertiveness through a Cooperative Confidence Building Program (CCB)." Id. at 495. For a sense of how the VWIL program operates in practice, see, e.g., Peter Baker, Cadets Test the Waters; For Women, a Dip, for Men, Immersion, at VMI, WASH. POST, Aug. 31, 1995, at C1 (describing even faltering VWIL students as receiving encouragement and positive reinforcement from those training them, including "smiles and a gentle nudge from the VMI cadet-instructors" brought in to drill them and quoting VMI cadets as saying, "We're usually not quite as nice," and "'It's not going to be the same as a VMI education"").

349. Given that it purports to utilize gender stereotypes only for the purpose of breaking them down, should the VMIVWIL plan be seen as more like the "provision of a men-only engineering school and a women-only nursing school," which the dissent in VMI II sees as clearly impermissible, VMI II, 44 F.3d 1229, 1249 (4th Cir. 1995) (Phillips, J., dissenting), or like the provision of a men-only nursing school and women-only engineering school? Whether one combination is more permissible than the other may turn on the precise extent to which it is the "archaic" rather than the "overbroad" character of such stereotypes that makes them constitutionally suspect. See supra note 332 .

Although the notion that excessive doses of masculinity will lead to a more feminine androgyny on the part of men is a fascinating one akin to the notion that a dose of some stimulants will soothe hyperactive children, there is very little support in the record of either the VMI or the Citadel case for this proposition. At least at The Citadel, if not also at VMI, cadets seem to be more encouraged to despise the feminine in themselves than to nurture it. Both the female and the feminine appear to be used throughout cadet training as a negative reference point. Thus, one Citadel English teacher warned cadets, "Never use the passive voice-it leads to effeminacy and homosexuality." Faludi, supra note 204, at 79. And Michael Lake, a former cadet interviewed by Faludi, described

a submerged gender battle . . . concealed from view by the fact that men played both parts. The beaten knobs were the women, "stripped" and humiliated, and the predatory upperclassmen were the men, who bullied and pillaged....

"They called you 'pussy' all the time," Lake recalled. "Or a 'fucking little girl."' It started the very first day they had their heads shaved, when the upperclassmen ... taunted, "Oh, you 
court's metaphor: "If VMI marches to the beat of a drum, then Mary Baldwin marches to the melody of a fife and when the march is over, both will have arrived at the same destination." 350

One major difficulty with the plan is what some might call its gender essentialism-the assumption that sex and gender are coextensive, ${ }^{351}$ that all males and only males have the masculine traits on which VMI is based and vice versa. ${ }^{352}$ For as the plan now stands, women gendered masculine, as by all accounts the named plaintiffs in the Citadel case may be, ${ }^{353}$ have

going to get your little girlie locks cut off?" When they learned that Lake would be playing soccer that fall, their first response was "What is that, a girl's sport?" Another former cadet ... . [nearly driven to suicide by his treatment] reported . . . [that v]irtually every taunt equated him with a woman ....

Id. at 70; see also Dianne Avery, Institutional Myths, Historical Narratives, and Social Science Evidence: Reading the "Record" in the Virginia Military Institute Case at IV.D.12 (Sept. 1, 1995) (unpublished manuscript, on file with author) (quoting former VMI commandant as saying "of course, the relative 'manliness' of the various sports is a major factor in according respect and status even among athletes"').

350. VMI II, 852 F. Supp. at 484 . Freudians would be fascinated by the sexual imagery here-a masculine beat pounded on a womb-like drum, a feminine melody blown on a phallic fife.

351. In a case where choice of terminology may be more than usually important, this assumption is reinforced by the courts' repeated, but not consistent, references to "single-gender education" to describe schools that are now each indeed "single-gender," as I have used that term, as well as "single-sex." See, e.g., VMI II, 44 F.3d at 1238 (using term "single-gender" six times in first four sentences of opinion, but going on to refer to "a sexually homogeneous environment").

352. Or, as the government's expert witness, Dr. Carol Nagy Jacklin, testified, the plan "homogenizes women by assuming that there is an appropriate way to educate women." VMI II, 852 F. Supp. at 479 . The court, oddly, thought Jacklin's testimony was refuted by her admission that men and women are treated differently in the classroom as evidenced by her observation that students at Mary Baldwin College were passive while the students at VMI were interactive. Id. at 480 .

353. Faludi describes the following cross-examination at trial by Robert Patterson, an attorney who represented both VMI and The Citadel, of Alexander Astin, an expert witness on education. Astin testified that he found:

no negative effects on male students in nineteen all-male colleges he had studied which had gone coeducational.

[Patterson:] "Can you tell me what kind of woman you would think would want to attend a coeducational Citadel? ...

Astin: I suppose the same as the kind of men who want to go there.

Patterson: Would it be a woman that would not be all that different from men?

Astin: Yes."

To Patterson, this was a triumphant moment, and he closed on it: he had forced the government's witness to admit that a woman like Shannon Faulkner would have to be a mannish aberration from her gender. But in fact Astin's testimony expressed the precise point that the plaintiff's side had been trying to make all along, and that The Citadel strenuousiy resisted: that the sexes were, in the end, not all that different. Faludi, supra note 204, at 73.

Faludi goes on to describe Shannon Faulkner as displaying various attributes coded masculine, from directness and brusqueness, $i d$. at 73, to individualism, $i d$. at 74, and an unwillingness to be pushed around, id. at 73. Faludi quotes Faulkner as saying "I never show my true emotions in public .... I consider that weak,"' $i d$. at 75, and recounts Faulkner's "memory that as a small child she preferred playing outside with the boys to playing with certain girls, whom she deemed "too prissy," id. at 73. As a "surprised Dean Poole commented" to Faulkner when she received her highest grade, an A, in calculus, she was "“certainly not the stereotypical woman."'Id. at 75; see also Linda L. Meggett, Girl with Citadel Ties Wants in Corps, ChARLESTON POST \& COURIER, Sept. 1, 1995, at A1 (quoting neighbor describing Nancy Mellette, Oak Ridge military high school senior who has sought to join Citadel case as plaintiff, as "kind of masculine, and very athletic"). 
no place in the Virginia system. ${ }^{354}$ As with the gendered job requirements discussed above, ${ }^{355}$ the gendered requirements imposed on students by VMI and The Citadel, on the one hand, and VWIL and SCIL, on the other, also come bundled. ${ }^{356}$ But VMI and The Citadel insist on aggregating sex and gender to a far greater extent than do employers today. Perhaps spurred by the requirements of Title VII, neither Sears nor the police continued to insist that being male was a BFOQ for the masculine jobs they were offering. If an exceptional woman demonstrated the masculine characteristics they sought, they stood prepared to hire her and they generally declined to hire males who lacked these characteristics. But for both schools, being male seems to be not only a necessary but also a sufficient predictor of the masculine traits their students are meant to demonstrate. Rather than make specific inquiry into

354. For a similar conflation of sex and gender based on sex stereotypes but nevertheless approved despite there being no space for exceptions to gendered expectations, see, e.g., Klinger v. Department of Corrections, 31 F.3d 727 (8th Cir. 1994) (sexed and gendered prison programs). It would not surprise most feminists to learn that most programs that essentialize and conflate sex and gender also seem to provide fewer resources, objectively measured, to the female/feminine side of the program. Thus, while VMI promises to put substantial monetary resources and alumni good will at VWL's disposal, the two programs can hardly be deemed comparable by any measure. Similarly, several court challenges to the lesser opportunities available in female/feminine prison systems have failed, sometimes with the courts accepting the seemingly paradoxical justification that, because females are less numerous and less serious offenders there is less demand for the services provided male prisoners. See, e.g., id. at 731. But see, e.g., West v. Virginia Dep't of Corrections, 847 F. Supp. 402 (W.D. Va. 1994) (holding that providing to male but not to female prisoners opportunity to attend "boot camp," which made them eligible for early release, was impermissible sex discrimination). Like VMI, the Virginia prison boot camp stressed military drill and physical training. Like The Citadel, Virginia prison officials argued that a comparative lack of demand among women, who were a small percentage of the overall prison population, justified providing boot camp facilities to men only. The court rejected this argument, noting that the evidence also indicated that women were at least as likely to benefit from the program as men. For a discussion of earlier cases on sex segregation and the provision of services in male and female prisons, see generally Rosemary Herbert, Women's Prisons: An Equal Protection Evaluation, 94 YALE L.J. 1182 (1985). The prison, and especially the VMI and Citadel cases, demonstrate yet again how very difficult it may be to make separate equal, especially when one begins with an inequality of long standing. I'll resist saying they also show how closely VMI and The Citadel, as presently constituted, resemble prisons.

355. See supra Part V.

356. Like those identified for gendered jobs, the gender bundles for each of the schools contain a variety of components, and those for the male/masculine school are the polar opposite of those for the female/feminine school. Not only is an "adversative" method contrasted with a "cooperative" one, but leveling with building self-esteem, as cures for respectively "aggression" and lack of "confidence." The classroom "passiv[ity]" of Mary Baldwin students is contrasted with "interactive" behavior at VMI, "elegantly equipped" residence halls at Mary Baldwin with spartan barracks at VMI, etc. Both VMI and The Citadel also seem to include in their bundles a heavy dose of the worst of masculinity, such as "violence, vulgarity and an obsession with winning and dominating." Hunter, supra note 79, at 153; see Faludi, supra note 204 , at $67,69,72$ (describing Citadel cadets' torture of each other, women, and small animals). This is one of the many reasons why Shannon Faulkner's battle to enter The Citadel put many feminists in an equivocal position analogous to that of some gay rights activists faced with the issue of gays in the military or gay marriage-they felt trapped into having to argue that a member of the group whose rights they were committed to defending should be permitted to do something that down deep they thought should not be done by anyone ever. And they were further forced into arguing, for exigent strategic reasons, that the admission of a member of their group would not change the institution she sought to enter, even though down deep they thought that change was exactly what such an institution needed and what opening it up might help provide. See, e.g., Nancy D. Polikoff, We Will Get What We Ask for: Why Legalizing Gay and Lesbian Marriage Will Not "Dismantle the Legal Structure of Gender in Every Marriage," 79 VA. L. REV. 1535, 1544-49 (1993). 
many of the personality traits or even into the physical abilities of prospective students, both schools seem to be concerned chiefly with whether applicants are male $^{357}$ and to assume that all the rest will follow. In the Title VII context, this would be retrograde in the extreme and patently illegal. But, inexplicably, the district court purported to find as a matter of fact-and the Fourth Circuit affirmed the proposition-that the differences in the two plans were "based on real differences, not stereotypes." To say the least, this holding completely misunderstands both the nature and the legal status of sex stereotyping. ${ }^{358}$

In addition to providing a textbook case of sex and gender stereotyping, the example of VMI and VWIL may help illustrate that one of the many appealing things about a separate conceptual space for gender discrimination could be that, dare I say it, it may help dissolve the sameness/difference divide in both sex discrimination law and feminist jurisprudence. ${ }^{359}$ Like

357. As Dianne Avery put it, "VMI's only non-waivable physical requirement for admission is that the applicant must be a male." Avery, supra note 349, at IV.D.15 (citing Brief for United States at 29 n.22, United States v. Virginia, 976 F.2d 890 (4th Cir. 1992) (No. 91-1690) (citing testimony of General John W. Knapp, Superintendent of VMI) (emphasis omitted). "While it was estimated that only about $15 \%$ of females in the pool of likely applicants could pass the physical fitness test on the first try, just over 50\% of the males who are admitted to VMI are able to pass the test when they start their first year." Id. (citations omitted). And two percent of VMI students are permitted to graduate without ever having passed the physical fitness test. $I d$. at IV.D.16.

358. The VMI II district court opinion repeatedly talked of the VWIL plan's component parts as being suitable for "women," usually without specifying whether it meant thereby some, many, most, or all women. But a careful reading of the court's findings reveals that the one thing it did not claim is that its findings are categorically true of women. But that is exactly what it would have to have found for its conclusions not to rest on stereotypes.

This is only one of the many respects in which both the district court's and the Fourth Circuit's approval of an all-male VMI and an all-female VWIL diverge, to the detriment of women, from the doctrinal standards for sex equality set forth in recent Supreme Court cases. A full discussion of the problems with these opinions is beyond the scope of this Article, but many of them are set forth in the dissent, VMI II, 44 F.3d at 1242 (Phillips, J., dissenting), and the dissent from the denial of rehearing en banc, 52 F.3d 90, 91 (4th Cir. 1995) (Motz, J., dissenting).

359. This is something feminist legal theorists have been trying to do for generations with, in my view, quite limited success. Notwithstanding a host of articles promising to get us beyond sameness and difference, only one approach is generally thought to be a serious contender-the dominance approach associated with Catharine MacKinnon. She instructs one to inquire with respect to any given legal rule or practice not whether it treats men and women the same or differently, but whether it contributes to the subordination of women or not. If it does, the rule should be changed whether the result would be to treat women the same as men or not. See, e.g., MACKINNON, supra note 85, at 40-45. But note that MacKinnon, while giving us an important way of focusing the question, doesn't quite succeed in allowing one to avoid a commitment to sameness or difference in answering it. The most MacKinnon seems to do is absolve one of the need for perfect consistency along a sameness/difference axis-she says that sometimes the answer can be to treat women the same and other times to treat them differently. But, for the difficult, open questions, the analysis still seems to turn on one's commitment to sameness or difference. Thus, for example, in considering what the legal response to surrogacy contracts should be, some feminist theorists see subordination in the commodification of the uniqueness of pregnancy (i.e., see difference as nonsubordinating) and others see subordination in a prohibition on women's right freely to contract to provide a service over which they have market power (i.e., see sameness as nonsubordinating). See Margaret Jane Radin, The Pragmatist and the Feminist, 63 S. CAL. L. REv. 1699, 1700 (1990) (describing as "double bind" the problem that "both commodification and non-commodification [of sexual and reproductive services] may be harmful . . . . under our current social conditions"). For another attempt to get beyond sameness and difference, less combative than MacKinnon's, also somewhat promising, although difficult to administer, see Christine Littleton's "equality as acceptance" approach. Littleton, supra note 63. 
courts deciding sex discrimination cases under the Constitution, feminist legal theorists have long been vexed by the question to what extent sex equality requires sameness of treatment for the two sexes, or, alternatively, what sorts of differences between the sexes may serve as the basis for requiring or permitting differences in treatment. ${ }^{360}$ Sameness theorists have been criticized for focusing on the exception to the detriment of the norm, for making the world safe for masculine women at considerable cost to the vast majority of feminine women and without challenging the masculinity of the standard against which women are measured. Difference theory, by contrast, has been seen to serve the norm well, but has been criticized for leaving little space for the exception. There is, however, as many feminist theorists have recognized, no necessity for accepting the existing masculine standard as the sex-neutral sameness standard around which to build: A standard that incorporates some or all of what is traditionally feminine can be no less a sex-neutral sameness standard, so long as it disaggregates sex and gender and allows for the possibility of both men and women to exhibit feminine as well as masculine behavior and life patterns. ${ }^{361}$

In the specific context of VMI and VWU or of The Citadel and SCIL, it would be both narrow-minded and short-sighted to see only two alternatives-one, a traditional sameness solution of admitting women to the established masculine school and rejecting the feminine one entirely, as the United States proposes in its petition for certiorari in the VMI case; ${ }^{362}$ the other, a traditional difference solution of approving the two programs in their existing single-sex and gender configurations, as the state of Virginia proposes in its opposition brief. ${ }^{363}$ Disaggregating sex and gender may help

360. In the VMI case, this sameness/difference question is most often phrased in the familiar language of "separate but equal," with the United States as plaintiff pressing strongly the view that "any parallel program would have to be 'identical' in substance and methodology to that of VMI," VMI II, 44 F.3d at 1235, and the Fourth Circuit characterizing this as "a needless, and indeed baseless, demand for conformity" because, in the court's view, "[s]ometimes the grossest discrimination can lie in treating things that are different as though they were exactly alike." Id. at 1240 (quoting Reed v. Reed, 404 U.S. 71, 75 (1971) and Jenness v. Fortson, 403 U.S. 431,442 (1971)).

361. For example, one could assume in structuring the workplace and the laws governing it that the paradigmatic worker was not, as in the past, a person without childcare responsibilities and with a spouse available to make life easier (i.e., a person with a stereotypically masculine biography). Rather, one could assume that the paradigmatic worker was more like the typical woman, who could not rely on her spouse to cook meals for her (let alone for her boss and out-of-town clients) and did have substantial childcare responsibilities. This would still be adhering to a standard of sameness, but the model on which the standard was based would be a stereotypically feminine, rather than a stereotypically masculine biography. This would mean, as many have noted, that the term "working mother" might no longer be seen as expressing some modification or deviation from the ideal types of both "worker" and "mother." See, e.g., Martha Minow, The Supreme Court, 1986 Term-Foreword: Justice Engendered, 101 HARV. L. REV. 10, 13-14 (1987).

Of course, the paradigmatically masculine and the paradigmatically feminine by no means exhaust the models around which a sex-neutral (but not necessarily gender-neutral) legal structure can be built.

362. See Petition for Writ of Certiorari at 26-29, United States v. Virginia (No. 94-1941).

363. See Brief for Commonwealth of Virginia in Opposition to Petition for Writ of Certiorari, United States v. Virginia (No. 94-1941). 
us to see that there may indeed be, as the Fourth Circuit suggested, "other more creative options or combinations." 364 Virginia might, as at least one commentator proposed, "pull every state tax dollar out of VMI and give it to VWIL."365 "It's going to be a great program. . . . Moreover, it's hard to see how admitting a man to VWIL would ruin it." ${ }^{" 366}$ This option, sounding in sameness but built on a feminine model, calls into question the value placed on the traditionally masculine and elevates the traditionally feminine into something valuable to both sexes. ${ }^{367}$ Another option, which one might call androgynous, would open up VMI and The Citadel not only to women, but also to a methodology that is less obsessively masculine and explicitly incorporates positive feminine elements. This appears to be what VMI and The Citadel fear will in fact happen if women are admitted, what some feminists may hope for from the integration of women, ${ }^{368}$ and what is reported to have happened at the service academies following women's

364. United States v. Virginia, 976 F.2d 890, 900 (4th Cir. 1992) (VMI I).

365. Jim Spencer, "Respect" for Women at Men's Schools Only in Manuals, ForT LAuderdale SUN-SENTINEL, Aug. 30, 1995, at 9A. Spencer claims, "Unfortunately that's not an option." Id.

366. Id.

367. As one of my masculine male colleagues said of VWIL, "That's the program I want to go to, the one where they say, when you don't hit the target, "That's OK, try again, you'll do better next time." Far from considering making the feminine program available to students of both sexes, however, South Carolina plans to condition its availability even to women on the continued existence of an all-male masculine Citadel. It has made clear that, if The Citadel is forced to admit women, the SCIL program will no longer be funded. See supra note 341 . This unquestioning acceptance of a masculine standard, at least for men if not also for women, or the failure even to consider the possibility of a feminine standard applied sex-neutrally, is one of the central problems of gender discrimination.

Throughout the VMI litigation, the state of Virginia and the trial judge did what feminist theorists have long criticized in both the legal system and employer hiring practices-they assumed the correctness of a masculine standard and asked only whether women could fit it, not whether it was an appropriate standard for persons of either sex. The VMI findings of fact went largely to the suitability of the masculine VMI methodology for women, rather than to the suitability of either the masculine VMI or the feminine VWIL methodology for men. See VMI II, 44 F.3d at 1241. Yet, when two of plaintiff's expert witnesses in the VMI case were asked on cross-examination whether they were aware of any educational authority that recommended "the adversative methodology for the education of women," the first, Carol Nagy Jacklin, responded, "No, nor for men." Avery, supra note 349, at VI.A.11 n.36 (citing Joint Appendix). Similarly, the second, Alexander Astin, answered, "I'm not sure there are any such authorities who advocate it for men." Id. Asked, "'What's your answer again, sir?" Astin repeated, "I say, I'm not sure there are any educational authorities that I'm familiar with who are advocating that form of education for men or women." Id.

But, like Sears and the police, the state of Virginia seemed deaf or indifferent to any suggestion that the masculine standard might be generally unsuitable to achieving its legitimate ends, even apart from any consideration of its discriminatory character. Cf. supra text accompanying note 287 (reciting evidence that a high masculinity score correlated with poorer salesmanship at Sears); supra text accompanying notes 290-328 (reciting evidence that masculine behaviors led to less effective policing). The state seemed more interested in preserving a masculine standard at all costs than in training the best possible citizen soldiers by the most suitable methods. Because it has established a feminine/female alternative only to defend the sanctity of the masculine/male model to which it seems unshakably committed, Virginia should be deemed to fail the third prong of the test for determining whether a sex-segregated state program violates the Equal Protection Clause established by the Fourth Circuit, which asks whether "the value of the benefits provided by the state to one gender tends, by comparison to the benefits provided to the other, to lessen the dignity, respect or societal regard of the other gender." VMI II, 44 F.3d at 1237.

368. See supra note 356. 
admission to them. ${ }^{369}$ Finally, one might retain both sets of programs as embodiments of the opposite poles of masculine and feminine, but open each up to members of either sex who are appropriately gendered; thus, both masculine men and masculine women could attend VMI or The Citadel, while VWIL and SCIL would admit those of both sexes more suited to or attracted by a more feminine approach. ${ }^{370}$

I began this Article by focusing, as sameness theory has for so long, on the exception, but on the opposite margin-on the effeminate man rather than on the masculine woman. In arguing that the treatment of the exceptional effeminate man teaches us much about that of both feminine and masculine women as well as masculine men, I hope to have shown how, once again, the margins can illuminate the center; and to have taken steps to make the world safe for us all, norms and exceptions, men and women, masculine and feminine, and every shade in between. By disaggregating gender from sex and sexual orientation focusing attention on the reasons why the feminine might have been devalued in both women and men, I hope to protect what is valuable about the traditionally feminine without essentializing it, limiting it to women, or limiting women to it.

369. In his appendix to VMI I, Judge Kiser found, for example, that integration of women at West Point was made possible by the Academy's move away from its adversative new cadet system to a much more developmental style of training and emphasis on positive leadership. ... . West Point has also acted to eliminate practices such as upperclassmen yelling at and disciplining new cadets ... [ [and h] azing of new cadets, including demeaning or insulting activity .... The new system uses positive motivation, instead of stress, as a means of leadership development.

VMI I, 766 F. Supp. app. at 1440-41. Some might see this as all to the good, for men as well as women, but not Judge Kiser, who focused only on what was lost in the move away from an adversative model. Again, his approach resembles that which MacKinnon and others have criticized both in traditional American law and early sameness feminism-it takes not only as given but as desirable a world constructed around a masculine model and asks only whether and how women can fit into such a world, without ever questioning the suitability of the model for either men or women. See supra note 93.

370. Of course, the fact that neither of the masculine programs and both of the feminine programs would have to change their names if they were to be opened to persons of both sexes, with the latter no longer calling themselves programs simply for "women in leadership," is one further, albeit minor, indication that at present the feminine is seen as limited to women while the masculine approaches the universal. 
HeinOnline -- 105 Yale L.J. 106 1995-1996 